Andrews University

Digital Commons @ Andrews University

\title{
A Biblically Based Strategy for Disciple-Making in the Seventh-day Adventist Churches of Malawi
}

Wenson Lyson Masoka

Andrews University

Follow this and additional works at: https://digitalcommons.andrews.edu/dmin

Part of the Practical Theology Commons

\section{Recommended Citation}

Masoka, Wenson Lyson, "A Biblically Based Strategy for Disciple-Making in the Seventh-day Adventist Churches of Malawi" (2006). Professional Dissertations DMin. 642.

https://dx.doi.org/10.32597/dmin/642

https://digitalcommons.andrews.edu/dmin/642

This Project Report is brought to you for free and open access by the Graduate Research at Digital Commons @ Andrews University. It has been accepted for inclusion in Professional Dissertations DMin by an authorized administrator of Digital Commons @ Andrews University. For more information, please contact repository@andrews.edu. 


\begin{abstract}
A BIBLICALLY BASED STRATEGY FOR DISCIPLE-MAKING

IN THE SEVENTH-DAY ADVENTIST CHURCHES

OF MALAWI
\end{abstract}

by

Wenson Lyson Masoka

Adviser: Gorden R. Doss 


\section{ABSTRACT OF GRADUATE STUDENT RESEARCH}

Dissertation

Andrews University

Seventh-day Adventist Theological Seminary

Title: A BIBLICALLY BASED STRATEGY FOR DISCIPLE-MAKING IN THE SEVENTH-DAY ADVENTIST CHURCHES OF MALAWI

Name of researcher: Wenson Lyson Masoka

Name and degree of faculty advisers: Gorden R. Doss, D.Min., Ph.D.

R. Clifford Jones, D.Min., Ph.D.

Date completed: November 2006

Problem

The current rapid growth of the church in Malawi lacks an on-going strategy to foster the membership increase and its spirituality. The failure to systematically train the laity as disciple makers has resulted in their under utilization. By default, the church has become clergy-dependent and the majority of the members warm the pews as mere spectators. Meanwhile, their conversions seem to be equated with disciple-making. There is need for a paradigm shift which will produce active lay persons who can adequately rise to the challenge of the Gospel Commission, making disciples of all nations. Although this research has a global impact, its main focus is on Malawi, a 
country with deep-rooted cultural practices and traditional discipleship models.

\section{Method}

The approach of the study was dictated by the definition of a disciple which is not synonymous with a convert in that a disciple reproduces faith in others and seeks to make them disciple makers too. The Old and the New Testament scriptures provided the foundational bedrock for this proposed disciple-making strategy in Malawi.

The primary sources included pertinent literature on discipleship, missiological and anthropological reflections, and personal experience. The strategy emphasizes the need for lay training and deep commitment by the church administrators.

\section{Conclusion}

There were models of disciple-making in the Bible times through which future kings, prophets, priests, and other national leaders served as interns before assuming their respective offices. The learners observed and worked closely with their mentors in public and in private settings. The system helped to prevent a leadership vacuum and ungodly influences from filtering into the nation.

Discipling is mentoring at best. Mentors shape the lives of their trainees. Both the ancient and the modern worlds have used mentors. Jesus called and mentored twelve uneducated men who became a nucleus of His church to reach the world nations.

This disciple-making strategy will multiply the number of productive lay persons, improve the quality of their spirituality, and greatly reduce the rate of membership backdoor losses. It will also increase the number of gift-oriented ministries. The local churches will be centers of spiritual renewal. Malawi will be a mission-minded church. 


\title{
Andrews University
}

Seventh-day Adventist Theological Seminary

\section{A BIBLICALLY BASED STRATEGY FOR DISCIPLE-MAKING IN THE SEVENTH-DAY ADVENTIST CHURCHES \\ OF MALAWI}

\author{
A Dissertation \\ Presented in Partial Fulfillment \\ of the Requirements for Degree \\ Doctor in Ministry
}

by

Wenson Lyson Masoka

November 2006 



\title{
A BIBLICALLY BASED STRATEGY FOR DISCIPLE-MAKING IN THE SEVENTH-DAY ADVENTIST CHURCHES \\ OF MALAWI
}

\author{
A dissertation \\ presented in partial fulfillment \\ of the requirements for the degree \\ Doctor of Ministry
}

by

Wenson Lyson Masoka

APPROVAL BY THE COMMITTEE:
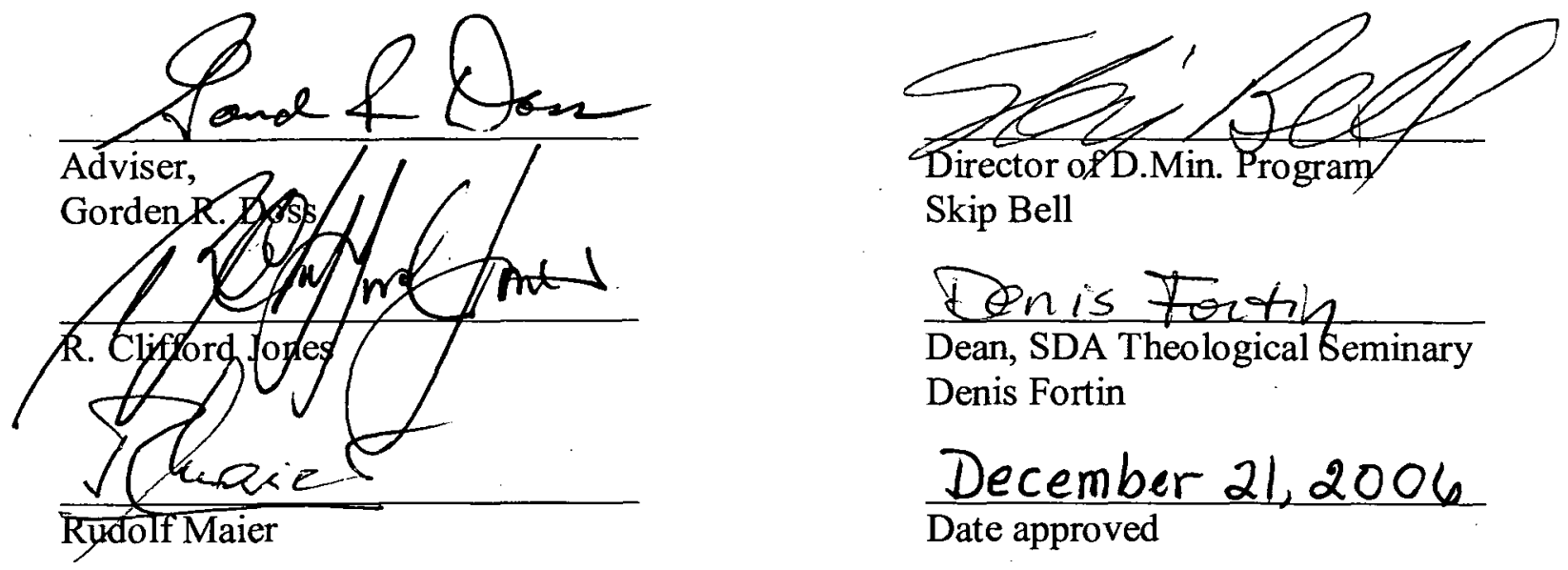

$\frac{\text { In is Fortih }}{\text { Dean, SDA Theological Seminary }}$

Denis Fortin

December 21,2006

Date approved 


\section{DEDICATION}

To

Rosemary Temwa Msiska-Masoka

for her love, companionship, faith, prayers, and inspiration

To

Rowena Mphatso, Rheeta Tamanda, Winnie Pilirani, and Wendy Thokozani Masoka for accepting, appreciating, and supporting me in the pastoral ministry which many times takes away their supposed quality time with me

To

Pastor Janton H. Mambala

for his love and dedication to disciple me as his own son in the pastoral ministry 


\section{TABLE OF CONTENTS}

LIST OF TABLES $\ldots \ldots \ldots \ldots \ldots \ldots \ldots \ldots \ldots \ldots \ldots \ldots \ldots \ldots \ldots \ldots \ldots \ldots \ldots \ldots$ viii

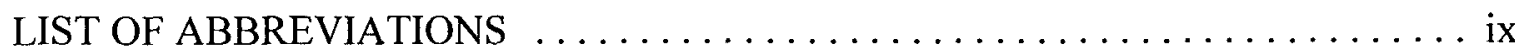

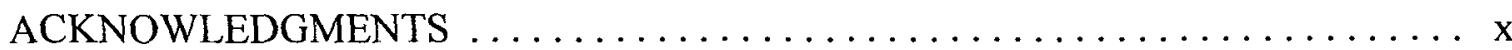

Chapter

1. THE MISSION OF THE CHURCH $\quad \ldots \ldots \ldots \ldots \ldots \ldots \ldots \ldots \ldots$

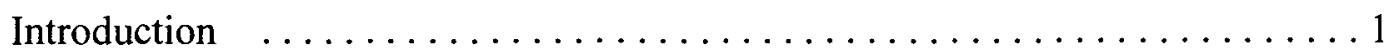

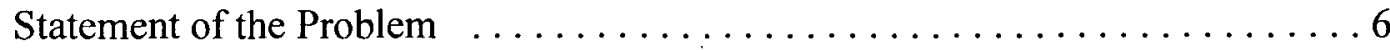

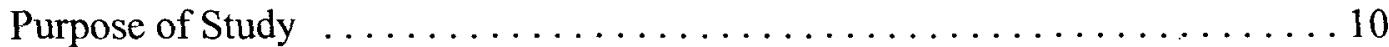

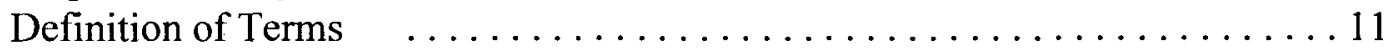

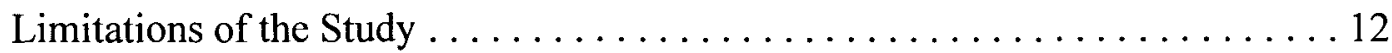

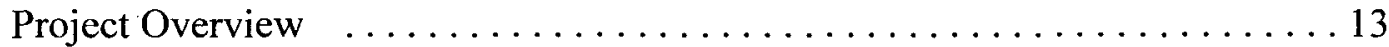

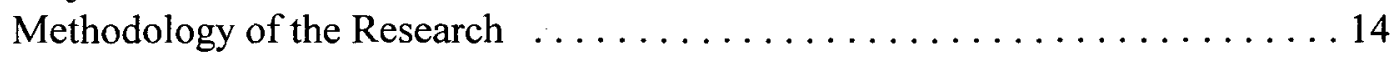

2. BIBLICAL AND THEOLOGICAL BASIS $\ldots \ldots \ldots \ldots \ldots \ldots \ldots \ldots \ldots \ldots \ldots \ldots \ldots \ldots$

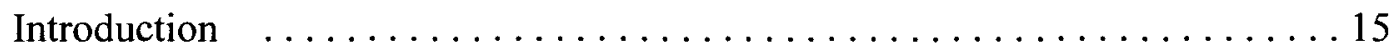

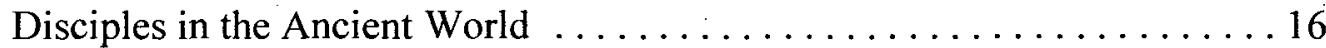

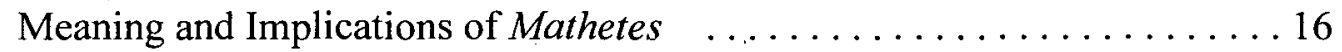

Roots of Discipleship ......................... 18

Approach to Missions: Centripetal and Centrifugal .............. 19

Old Testament Models . . . . . . . . . . . . . . . . . . . . . 23

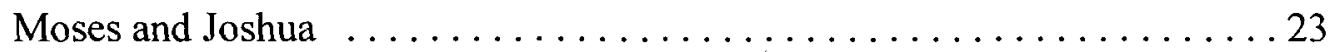

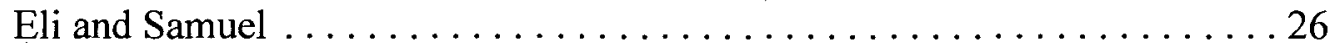

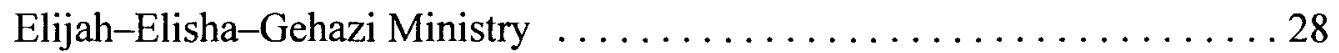

Character and Legacy of a Disciple . . . . . . . . . . . . . . 29

Discipleship Roots in the Old Testament ................ 30

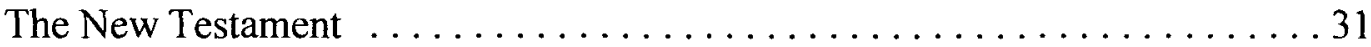

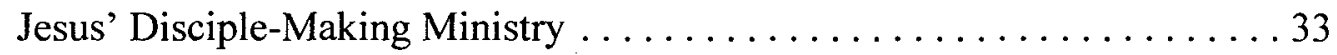

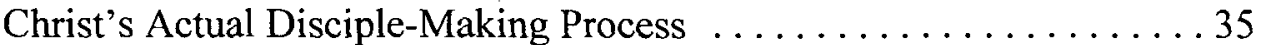

Discipling Family Members and Associates $\ldots \ldots \ldots \ldots \ldots \ldots . \ldots 42$

Apostle Paul ................................... 43

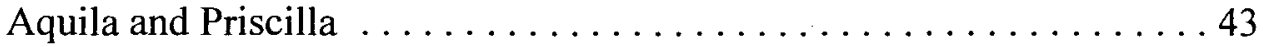

Timothy and Titus ........................... 44

Discipleship and Spiritual Maturity $\ldots \ldots \ldots \ldots \ldots \ldots \ldots \ldots \ldots \ldots$ 
Dimensions of Growth $\ldots \ldots \ldots \ldots \ldots \ldots \ldots \ldots \ldots \ldots \ldots \ldots \ldots$

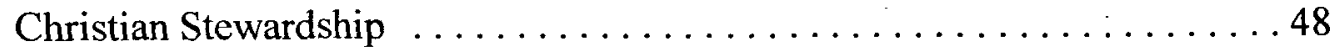

Priesthood of All Believers . . . . . . . . . . . . . . 50

Clergy and Laity: Partners in Discipleship . . . . . . . . . . . . 52

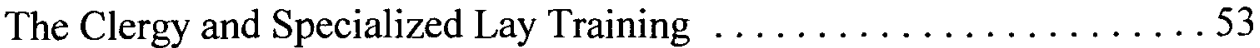

The Laity of the Church . . . . . . . . . . . . . . . . 55

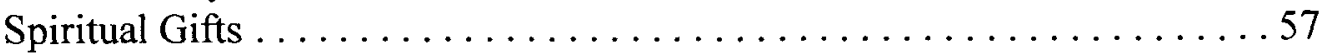

The Great Commission . . . . . . . . . . . . . . . . . 64

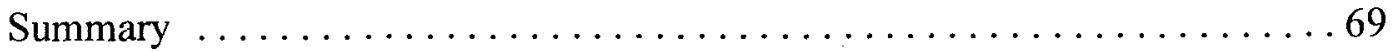

3. ANTHROPOLOGICAL AND MISSIOLOGICAL REFLECTIONS $\ldots \ldots \ldots \ldots 71$

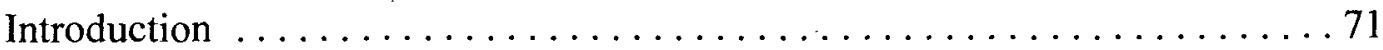

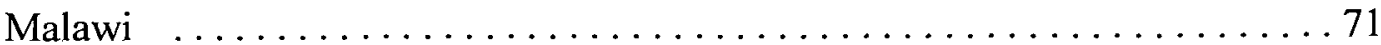

The Christian Pioneer Missionaries . . . . . . . . . . . . . . . . . 72

The Content of the Message $\ldots \ldots \ldots \ldots \ldots \ldots \ldots \ldots \ldots 77$

Seventh-day Adventist Beginnings $\ldots \ldots \ldots \ldots \ldots \ldots \ldots \ldots \ldots$

Joseph Booth and Adventist Work in Malawi . . . . . . . . . . 880

Growth of the SDA Work .................. . 84

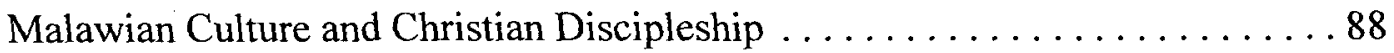

Traditional Religion . . . . . . . . . . . . . . . . . . . 92

Myths about God and Human Sufferings . . . . . . . . . . . 96

Fear and Witchcraft Culture . . . . . . . . . . . . . . . 98

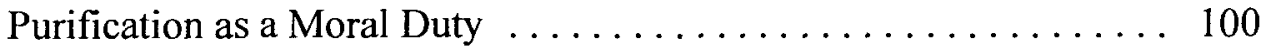

Bridges to Discipleship . . . . . . . . . . . . . . . 102

Chain of Command . . . . . . . . . . . . . . . . . . 104

A Go-Between Culture . . . . . . . . . . . . . . . . . 106

Nkhoswe and Cultural Respect for the Elderly . . . . . . . . . . 107

Communication Bridges to Discipleship . . . . . . . . . . 109

Traditional Forms of Discipleship . . . . . . . . . . . . . . 112

Chieftainship Preparation . . . . . . . . . . . . . . . . . 113

Celebrated Counselor (Nankungwi) . . . . . . . . . . . . . 114

Discipling an African Medicine Doctor . . . . . . . . . . . . 115

Bridges to Succession Discipleship . . . . . . . . . . . . . . 118

Status Orientation . . . . . . . . . . . . . . . . . . . . 120

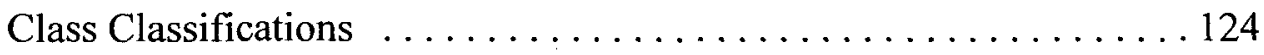

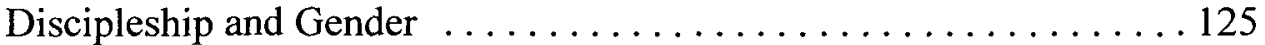

The Challenge of Reaching the High Class . . . . . . . . . . . 126

Bridges to Achievement Discipleship . . . . . . . . . . . 127

Rites of Passage . . . . . . . . . . . . . . . . . . . . . . . . . 128

Phases of Rituals . . . . . . . . . . . . . . . . . . . . . . 129

Rites of Puberty Passage (Chinamwali) . . . . . . . . . . . . 131

Nyau Rites of Passage . . . . . . . . . . . . . . . . . . . 134

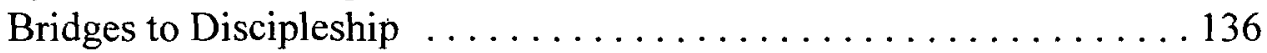

Summary .................................. 139 


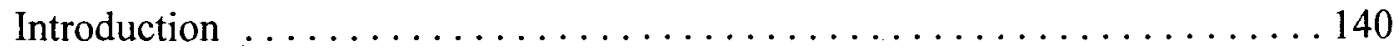

Education of Established Church Members . . . . . . . . . . . . . . . . . . 142

Modeling for the New Converts . . . . . . . . . . . . . . 146

Bible Study . . . . . . . . . . . . . . . . . . . . . . . . 149

Prayer Life ................................... 151

Christian Lifestyle . .......................... 154

Leading a Soul to Christ ......................... 159

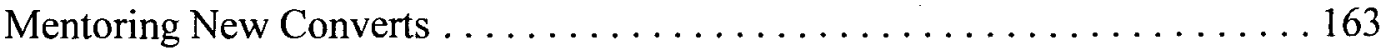

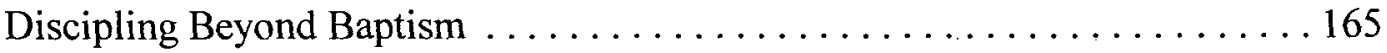

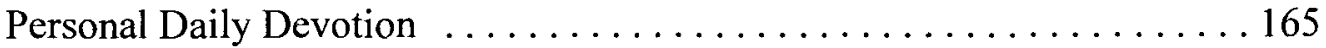

Sharing Christian Joy with Others $\ldots \ldots \ldots \ldots \ldots \ldots \ldots \ldots \ldots \ldots \ldots \ldots \ldots \ldots$

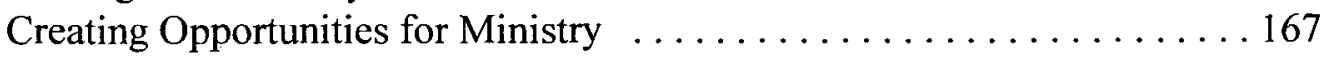

Sermon Preparation and Delivery $\ldots \ldots \ldots \ldots \ldots \ldots \ldots \ldots . \ldots \ldots$

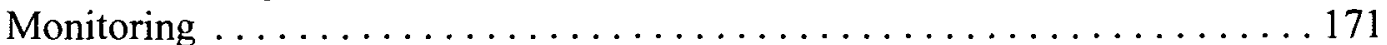

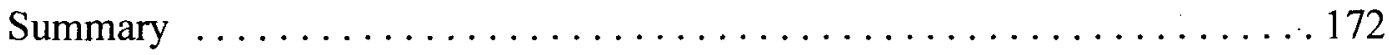

5. DISCIPLESHIP TEACHING STRATEGY $\ldots \ldots \ldots \ldots \ldots \ldots \ldots \ldots \ldots \ldots \ldots$

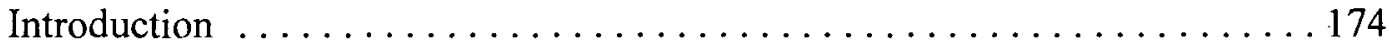

Leadership Recruitment ........................... 176

Steps for Strategy Implementation $\ldots \ldots \ldots \ldots \ldots \ldots \ldots \ldots \ldots \ldots \ldots \ldots$

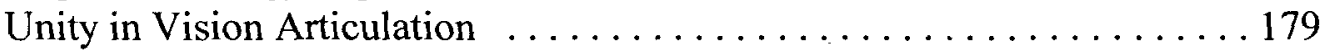

Selection Process ................................. 180

Successful Discipleship with Ten People $\ldots \ldots \ldots \ldots \ldots \ldots \ldots 182$

Skill Development for Pastors . . . . . . . . . . . . . . 183

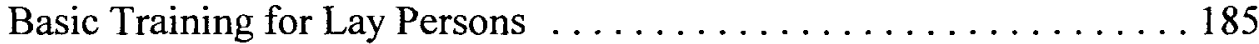

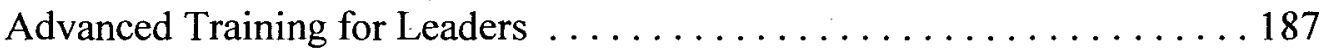

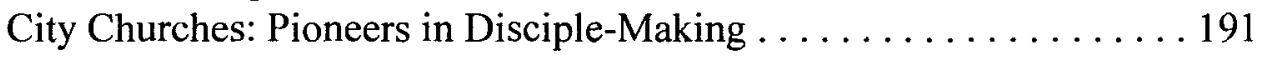

Leaders in Teams of Two . . . . . . . . . . . . . . . . . . . . . 192

Age Consideration ................................ 193

Gender Sensitivity ........................... 195

Geographical Location . . . . . . . . . . . . . . . . . . 195

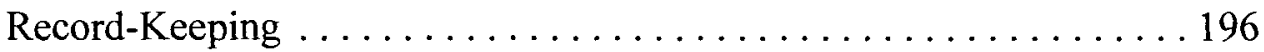

Certification of the Participants . . . . . . . . . . . . . . . 198

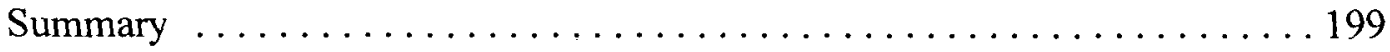

6. SUMMARY, CONCLUSIONS, AND RECOMMENDATIONS $\ldots \ldots \ldots \ldots 202$

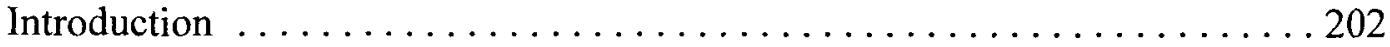

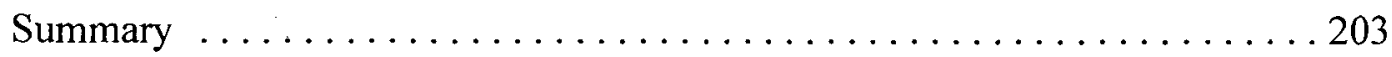

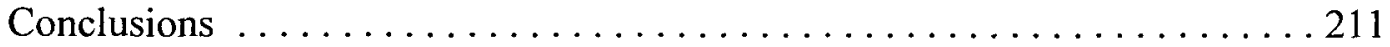

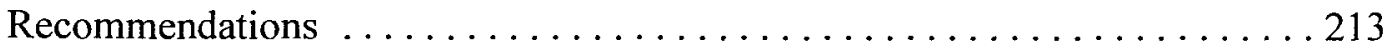


A. Five Short Topical Sermons .......................... 218

B. Application for Conference Status Survey Team ................. 224

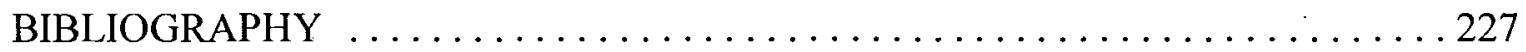

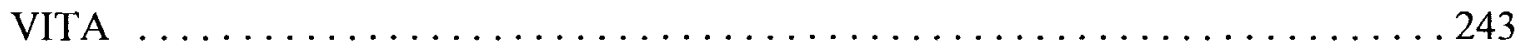




\section{LIST OF TABLES}

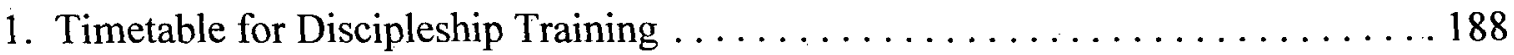

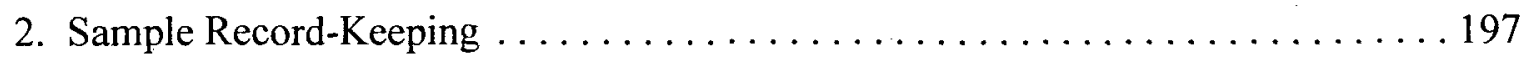




\section{LIST OF ABBREVIATIONS}

ATR

African Traditional Religion

CLF

Central Malawi Field

CCAP Church of Central Africa Presybeterian

D.Min. Doctor of Ministry

ECS Established Church of Scotland

GC General Conference

HIV Human Immunodeficiency Virus

KJV Kings James Version

MU Malawi Union

NEB $\quad$ New English Bible

NIV New International Version

NGO Non-Government Organization

NMF North Malawi Field

SDA Seventh-day Adventist

SID Southern Africa Indian Ocean Division

SMF South Malawi Field

UFC United Free Church of Scotland

UMCA Universities' Mission to Central Africa 


\section{ACKNOWLEDGMENTS}

This dissertation is a miracle and a testimony to God's power, goodness, faithfulness, and bountiful grace. My dreams for advanced studies were almost shattered. Finances and unsuspected health challenges looked insurmountable. My God defied all odds. He opened one of His unknown thousand ways, worked out a J-1 Visa for me, and touched the least expected people who provided funds for six air tickets to enable me and my family to come to the United States. My present health and this achievement are clear demonstrations of His enabling and amazing grace. Majesty and honor belong to Him!

I wish to also pay special tribute to my wife and best friend, Rosemary Temwa (Nyausiska). I salute her for the unwavering faith in God, support in all my years of ministry, and for her encouragement to take this educational break. This dissertation is dedicated to her and our children: Rowena Mphatso, Rheeta Tamanda, Winnie Pilirani, and Wendy Thokozani. Thank you for your love and support!

I wish to acknowledge help from my brother and trusted colleague in God's service, Gorden Doss. Achimwene, zikomo kwambiri for everything and your willingness to mentor me through this dissertation process. I am also indebted to the members of my dissertation committee, MU administrators, Ivan and Loraine Crowder, Victor and Alma Brown, Dave and Dee Forsythe, Linda Bauer, and Pastor Janton H. Mambala, my spiritual father in the gospel ministry. May God give everyone of us a double portion of His Spirit for discipling of nations. 


\section{CHAPTER 1}

\section{THE MISSION OF THE CHURCH}

\section{Introduction}

The Gospel Commission, "go and make disciples of all nations" (Matt 28:19) ${ }^{1}$, is a clear mission statement for the church. Jesus gave these marching orders with full authority "to impress the disciples with the thought that they held in trust the message of Heaven for the world."2 In the words of Ellen White, the church is "God's appointed agency for the salvation of men. It was organized for service and its mission is to carry the gospel to the world." ${ }^{3}$ The mission needs more laborers (Matt 9:37).

The Gospel Commission assignment goes beyond all geographical borders and racial groupings. It is a global mission. Jesus empowered the "disciples to proclaim the faith and worship that would have in it nothing of caste or country, a faith that would be

'Unless otherwise stated, all the Bible references in this paper are from the New International Version (NIV) (Grand Rapids, MI: Zondervan Bible Publishers, 1978).

${ }^{2}$ Ellen G. White, Upward Look (Washington, DC: Review and Herald Publishing Association, 1982), 100.

${ }^{3}$ Ellen G. White, The Acts of the Apostles (Boise, ID: Pacific Press Publishing Association, 1911), 9. 
adapted to all peoples, all nations, all classes of men." This is an age-long mission.

The church of the twenty-first century faces several challenges. The world population is many times more than it was at the time the commission was given. The nations are caught up in ceaseless conflicts and wars. In addition, some regions of the world are unfriendly to Christian discipling. The challenge becomes even greater in that Christ's continued presence with the disciples depends on the faithfulness of the believers in discipling the nations (Matt 28:20).

Jesus gave the disciples not only the task, but also the divine strategy to meet this greatest challenge ever given to man. The disciple-making strategy which the church seems to have lost, requires wise planning and intentional investment of time and resources. It calls for a new approach to pastoral ministry. It includes reaching out for souls, parenting them in the truth, and deploying them in the work. This "process of choosing students, teaching, mentoring, experimenting and placing them in needy situations, is a strong feature of the New Testament discipling procedures."2 Christ's divine strategy aims at involving every believer of the gospel.

Scripture shows that the early Christian disciples understood the enormity of their responsibility. They became fearless and focused on making disciples of all nations (Acts $4: 2,18-20 ; 5: 25-42)$. Persecutions in Jerusalem became a catalyst to spread the gospel to far places. The disciples co-operated with the angels. One example is that of Philip who was sent by an angel from Samaria to Gaza, south of Jerusalem, where he studied the

${ }^{1}$ Ellen G. White, The Desire of Ages (Boise, ID: Pacific Press Publishing Association, 1940), 820.

${ }^{2}$ Bob Hunt, "Training for God's Mission-An Historical Overview," Church Growth Digest 20, no. 1 (Autumn 1998): 8-9. 
Scriptures with an Ethiopian government official. Philip taught and baptized this African convert (Acts 8:4-8, 26-40). This is exactly what Jesus planned, that "men were to be His method of winning the world to God." It is the duty of every church leader to know and implement this biblical disciple-making strategy.

The clergy's most important work is to develop disciples from the laity in the local churches. ${ }^{2}$ This is a paradigm shift from emphasis on preaching and administrative work. When the clergy develops disciples, it also increases the leadership base of the local church. Effective disciple-making demands discipline of the clergy not to sidetrack.

By nature, human behavior resists change. The "shift from sameness to difference" ${ }^{33}$ can be stressful, confusing, and frustrating to both pastors and lay persons. Clear communication of the change and avoidance of a blame game from the past can help to minimize stress levels. The pastor can express appreciation for the participating members which will motivate them to take this additional challenge of discipling others to real Christian maturity.

Modern technology has helped to make significant advancement in the spread of the gospel to the unreached nations of the world. The Christian church has witnessed an increase in radio, television, satellite, and on-line ministries. Unfortunately, these ministries fall short of the ideal in that they lack a human touch which is an important

\footnotetext{
${ }^{1}$ Robert E. Coleman, The Master Plan of Evangelism (Westwood, NJ: Fleming H. Revell Company, 1964), 21.

${ }^{2}$ Thomas A. Skrenes, "Inventing the Future," The Clergy Journal 75, no. 5 (March 1999): 14.

${ }^{3}$ Gilbert R. Rendle, Leading Change in the Congregation (Bethesda, MD: Alban Institute Publication, 1998), 5.
} 
element in disciple-making. There is no substitute for mutual human interactions which provide critical aspects of discipling, nurturing, and mentoring.

The Seventh-day Adventist Church leadership is putting much emphasis on systematic discipleship. During the $58^{\text {th }}$ General Conference Session of the church that met in St. Louis, Missouri, Mark Finley, one of the main presenters during the Ninth Business Meeting on July 5, 2005, had this to say on discipleship:

The Great Commission was "Go and make disciples of all nations, baptizing them in the name of the Father and the Son, and the Holy Spirit" (Matt. 28:19, NIV), so baptism should take place after one has become a disciple of Christ. So the focus should not be baptism. The Great Commission is "Go and make disciples," and it includes much more than baptism. Disciple making is the development of a faithfilled group of people who are praying Christians, who are daily growing in grace studying God's Word, worshiping with His people, and witnessing to the glory of His name. When the church fails to nurture new converts, it really fails in accomplishing the Great Commission, and it's not faithful to God. ${ }^{1}$

This model of disciple-making does not do away with the traditional evangelistic methods. If anything, it strengthens it. At the same time, its primary focus is not baptism. The emphasis is to help the new believers attain daily growth in grace. They are to be nurtured through the study of God's Word, prayer, worshiping, and witnessing. Their baptism comes after these converts have already demonstrated their maturity by leading others to Christ. Active participation in disciple-making would improve the quality of ministries in the church and at the same time multiply the number of those services. Phillip Samaan is right to say that the church's great and urgent challenge today is "not merely adding more members, but reproducing and multiplying fruit-bearing

'Mark Finley, "Challenges to Missions," Adventist Review, July 5, 2005, 20. 
disciples."1 This model of disciple-making will speed up the work and in the process help the people to "grow in spirit and in truth, in holiness and perfection, ready to meet their Lord."

The Great Commission demands total obedience and acceptance that "God wants you to come into sympathy and harmony with His plans. ${ }^{n 3}$ The first duty for the church leaders and pastors in Malawi is to systematically sensitize the current baptized members about biblical discipleship. There is need for total mobilization of every church and company to have an ongoing discipleship. The goal is to develop and raise every established member and new convert into a productive disciple. This objective can be realized provided there is clear communication, wise planning, and training.

A biblical disciple-making strategy requires prayer, patience, and dedication of the church leaders in their work with the lay persons. The process of developing disciples takes time. It calls for real perseverance in prayer (Luke 18:1-4). Leaders need to exercise much patience and continue to "educate, educate, and educate."4 Another

'Phillip G. Samaan, "Transformed in Christ for Discipleship," Adventist Review, July 8, 2005, 13 .

${ }^{2}$ Gottfried Oosterwal, Patterns of SDA Church Growth in America (Berrien Springs, MI: Andrews University Press, 1976), 70.

${ }^{3}$ Ellen G. White to David H. Lamson, 13 December, 1888, Letter 48, 1888, Ellen G. White Research Center, Andrews University, Berrien Springs, MI.

${ }^{4}$ Ellen G. White, Evangelism (Washington, DC: Review and Herald Publishing Association, 1974), 528. 
element is seen in the life of apostle Paul when he continued laboring at Ephesus despite the severe test and many setbacks (Acts 20:17-19). It was Paul's life of dedication that qualified him to be a model of all Christ's followers through the ages.' Church leaders need the degree of dedication that will withstand all tests of their faith.

\section{Statement of the Problem}

In recent years, the Seventh-day Adventist Church has been experiencing an unprecedented growth in membership worldwide. The degree of growth may differ from one geographical area to another, but on the average, the whole church has witnessed some significant increase in membership. In a report to the session members in St. Louis, Missouri on July 1, 2005, Bert Haloviak, General Conference Archives and Statistics Director, said more than 5 million people joined the church between 2000 and end of 2004, making the church that had 972,000 members in 1954 grow to $13,936,932$ by the end of 2004..$^{2}$ This phenomenal growth is largely due to the church's strong emphasis on evangelism. The disturbing thing is that more than 1.4 million members left the church during the same period of time. This might be an indication of a problem. The growth in membership can be sustained by an active disciple-making strategy which produces not only quantity but also quality growth in those members.

Richard William Penn thinks that appeals in evangelism seem to be a "call merely

'James T. Dyet, Getting Through to Adults: Survival and Success in the Adult Classroom (Denver, CO: Accent Books 1980), 26.

${ }^{2}$ Bert Haloviak, "Second Business Meeting," Adventist Review, July 4, 2005, 29. 
to believe, only at a single point in time, in Christ as the Savior from sin, but ... not to follow Him in a holy life of service to God and humanity." Biblical discipleship is a call to a daily commitment of life in a walk with Jesus. The church needs to be made aware that disciple-making is not a one-time event. It is first and foremost, the main business of the church and cannot be seasonal. It needs to always be a top priority throughout the year. Disciple-making is a ministry that has no rival in the church.

Sometimes the church members or groups of believers keep themselves so busy in church activities that do not contribute much to the Great Commission. It is common especially for women, youth, and various singing groups to travel to sister churches to present programs. These kind of activities do not advance the cause of the Great Commission. They are like a social club serving members only. Disciple-making strategy has an in-reach and an out-reach dimension.

The members can learn a lesson from the Old Testament story of a guard who was charged to strictly keep a captive or else risk his own life. He lost the prisoner because he became so absorbed in other things ( $1 \mathrm{Kgs} 20: 35-42)$. What is it that takes the church time and resources? Can the church really afford to do God's business as usual? According to Robert J. Marshak, "Change of a mindset is one important factor to consider in transformational change."2 Church leaders need to change the members'

'Richard William Penn, "The Call to Discipleship: A Matthean Model for Contemporary Evangelism" (Ph.D. diss., Southern Baptist Theological Seminary, 1989), 6.

${ }^{2}$ Robert J. Marshak, "Introduction: Transforming Thoughts About Change," The Journal of Applied Behavioral Science 41, no. 2 (June 2005):157. 
mindset on priorities. The church needs to know that its sole responsibility is to make disciples by teaching them thoroughly according to the Gospel Commission.

Historically, the practice in Malawi Union was to teach new converts for two years before baptism. This has changed with the coming of big evangelism teams from abroad. Today, there are instances where people are baptized after twenty-one days of intensive evangelistic meetings. Time period might be of little effect. ${ }^{1}$ The real problem is that baptism has become like graduation from some prescribed studies. Baptisms seem to be a public ceremony for weaning the new converts from nurturing. New members are left idle with no plans for their continued growth to Christian maturity. The church lacks an ongoing process to foster personal spiritual growth of individual members. As a result, this has far-reaching implications for the church, its mission, and the second coming of Christ.

Traditionally, the Seventh-day Adventist Church has viewed the Great Commission to "make disciples" as "carrying the gospel to the world." In another place it reads: "Becoming a disciple involves thorough instruction." It does not go far enough though, to articulate disciple-making prior to and after baptism. Witnessing seminars have basically been held with a focus on how to get decisions and win new members.

'In 1985, Harry Cartwright, then Ministerial Secretary for Eastern Africa Division, concluded his 21 days evangelistic campaign in Blantyre with about 300 baptized converts. He introduced a "guardianship plan" to nurture these people and as a result we had good retention rate especially at Sunnyside Church where I was a member. Most of those people are seen holding church offices today.

${ }^{2}$ Seventh-day Adventists Believe ... A Biblical Exposition of 27 Fundamental Doctrines (Hagerstown, MD: Review and Herald Publishing Association, 1988), 142.

${ }^{3}$ Ibid., 188. 
There has not been a concise clear statement on disciple-making. Even the church's 27 fundamental doctrinal beliefs does not have a sharpened, articulated statement on disciple-making. Emphasis on character transformation, daily reading of the Bible, prayer, church attendance, tithing, and witnessing is not good enough because it leaves out the responsibility of disciple-making.

The additional statement voted during the session in St. Louis, Missouri, entitled, "Growing in Christ," does not directly address disciple-making as the title may seem to suggest. ${ }^{1}$ The statement basically deals with Christian growth in general terms and states that the members do not have to live in fear of anything because "by His cross Jesus triumphed" over all evil including evil spirits which some members still fear. ${ }^{2}$

The burden of this research is to show that as a strategy, discipleship is critical to the task of making disciples of all the nations in Malawi. Having a strategy is also an important factor in a believer's real spiritual maturity. A proven, field-tested strategy is needed to enable the church to finish the work of discipling the nations in Malawi. As long as the church exists, the Gospel Commission remains its real business. No church congregation has any justification to exist if it neglects or does away with disciplemaking. ${ }^{3}$ God's primary and direct call for every church member is to discipleship. ${ }^{4}$ All

'Mickey Nickless, "Growing in Christ-A New Statement of Fundamental Belief," Adventist Review, July 5, 2005, 10.

${ }^{2}$ Ibid.

${ }^{3}$ Bill Easum, Unfreezing Moves: Following Jesus into the Mission Field (Nashville: Abingdon Press, 2001), 10.

${ }^{4}$ Gary W. Moon and David G. Benner, eds., Spiritual Direction and the Care of Souls (Downers Grove, IL: InterVarsity Press, 2004), 93. 
7. Obeying Christ's command to disciple the nations.

This paper is intended to be much more than an academic exercise. It deals with an urgent core issue of saving people of all nations.

\section{Definition of Terms}

Disciple: In this paper, the word "disciple" is to be understood to mean more than a follower of Christ, more than a convert. Webster's Dictionary defines the word disciple as "one who receives instruction from another; one who accepts the doctrines of another and assists in spreading or implementing them." This definition covers more than the traditional understanding of a disciple. It makes a difference between a convert and a disciple. A convert accepts Christ. The new dimension of a Christian disciple is one who assists to spread the gospel to others until they too become disciple makers.

Church: Unless otherwise indicated, the word "church" refers to the Seventh-day Adventist Church in Malawi which is made up of local churches.

Company: A "company" refers to a local congregation of believers not yet granted official status of an organized church. There are many such congregations in Malawi, especially in the rural areas. Reasons may range from lack of necessary articles for communion service to a membership of less than 50 , which is the minimum for an organized church. These congregations are part of a local mother church in the vicinity.

The Seventh-day Adventist Church has an administrative hierarchy made up of the General Conference, the Division, the Union and a Conference or Mission Field. ${ }^{2}$

${ }^{1}$ Webster's Third International Dictionary of the English Language, (1966), s.v., "Disciple."

${ }^{2}$ General Conference Working Policy, 2004-2005 edition, 47. 
General Conference: The "General Conference" (GC) is an administrative body for all the Adventist church work and its various institutions in the whole world.

Division: The "Division" is an administrative unit in an assigned territory to carry out the responsibilities of the GC in that section of the world. It is in reality a GC extension. Malawi falls under the Southern Africa Indian Ocean Division (SID).

Union: The "Union" is a local administrative unit of the Division granted status by the act of the General Conference in session. Malawi Union (MU) is responsible for all the church work in Malawi. The Union has health and educational institutions plus a publishing house. MU was organized in 1925. ${ }^{1}$ It has offices in Blantyre and is under the Southern Africa-Indian Ocean Division.

Conference/Mission/Field: The "Conference/Mission/Field" refers to a small local unit granted official status by the act of the Union in session. It is an extension of the Union. MU has three such units, namely: North Malawi Field (NMF), Central Malawi Field (CMF), and South Malawi Field (SMF). These are divided according to the geographical regions in the country.

District pastor: The "district pastor" is the title given to gospel ministers because on the average, a pastor takes care of about twenty-five organized churches and companies. The territory where the pastor serves is known as a pastoral district.

\section{Limitations of Study}

Discipleship has several phases or facets. This study does not pretend to address

${ }^{1}$ Seventh-day Adventist Yearbook (Hagerstown, MD: Review and Herald Publishing Association, 2005), 306. 
every facet of discipleship. The aspects discussed in this paper are those that seem relevant to the Malawian context related to the reproduction of Christian disciples.

The contextualized model for disciple training in Malawi is based on universal biblical principles. This means that there are principles in this research that could be implemented anywhere but with adaptation. However, certain elements of the model may have validity for the Malawian context only.

\section{Project Overview}

This project is divided into six chapters that vary in size.

Chapter 1 introduces the thesis, purpose of the study, problem, definitions, limits of the study, dissertation overview, and methodology.

Chapter 2 provides a biblical and theological basis for discipleship strategy. It traces the word "disciple" in both secular and religious circles. It shows that some type of discipleship was practised in the Old Testament which gives a strong foundation for discipleship in the New Testament. Models from both Testaments are cited to lend more support and to ensure that the proposed strategy is Bible-based. Discussion on spiritual maturity, Christian discipleship, doctrine of priesthood of all believers, and the Great Commission are also included to further show practicality of discipleship in today's life and practice.

Chapter 3 looks at discipleship through the lenses of anthropological and missiological reflections. It explores traditional practices in religion, chain of command, forms of discipleship, status orientation, rites of passage, the impact of Christian pioneer missionaries to Malawi and people's response. Brief information regarding the Seventhday Adventist Church is also presented since it is the central focus of the whole study. 
Chapter 4 gives the role of education in discipleship, modeling new converts, Bible study, prayer, Christian lifestyle, and how to lead a soul to Christ. The chapter is enriched by inclusion of mentoring beyond baptism, personal devotional lifestyle, joy of sharing with others, and monitoring the results.

Chapter 5 deals with a strategy for the actual development of leaders among pastors and lay persons. It also includes advanced training where old and new members are paired together while being sensitive to age, gender, and location. This sensitivity does not ignore spiritual maturity of the established member. The chapter ends with recruitment, a step-by step training process, and certification of the participants.

Chapter 6 draws an overall summary, conclusions, and recommendations to the administrators and local churches.

\section{Methodology of the Research}

This research was based on findings from different authors on the subject. However, the uniqueness of this project lies in the fact that this discipleship strategy is proposed in the context of the rich hidden Malawian cultural practices. In view of this, a deliberate attempt was made to research from Malawian authors who have written in connection with areas of this study. In addition to this, a number of interviews were also conducted with selected Malawians. Any contribution by the Western authors is adapted to the culture of the people addressed by the project.

The study utilized Scripture, pertinent literature on the subject, notes taken during various courses of study as well as from independent classes. In addition, the writer used personal experience acquired in the literature work during college years in Zimbabwe and from the various levels of pastoral ministry in Malawi. 


\section{CHAPTER 2}

\section{BIBLICAL AND THEOLOGICAL BASIS}

\section{Introduction}

God yearns for relationships. He followed Adam after his $\sin (\mathrm{Gen} 3: 9)$. He told Moses and the children of Israel to build Him a sanctuary so He could "dwell among them" (Exod 25:8). Jesus is "Immanuel," meaning "God with us" (Matt 1:23). Jesus left heaven's glory on one mission "to seek and to save ... the lost" (Luke 19:10). He wants everybody saved (John 3:16; 1 Tim 2:4). People need someone sent to form friendships and preach to them (Rom 10:14-15). Jesus recruited disciples and trained them for the mission. After training the disciples, He sent them into the world (John 17:18). Their work continues until the end of the world.

The mission to reach the whole world with the gospel was probably the biggest challenge ever given to man. The end of the world partly hinges on accomplishment of the mission (Matt 24:14). God's concern for the world is emphasized at the beginning and at the end of Scriptures. ${ }^{1}$ Abraham left his birth place in order to be a blessing to the nations (Gen 12:1-9). This concern for nations appears again at the end of the Bible where both speed and human messengers are symbolized by the angels (Rev 14:6).

${ }^{1}$ Michael A. Grisanti, "Israel Mission to the Nations in Isaiah 40-55: An Update," The Master's Seminary Journal 9, no. 1 (Spring 1998): 39. 
Jesus entered into His public ministry with the same concern for the nations. His answer to the challenge was a radical disciple-making strategy. The concept of discipleship did not originate with Jesus. The practice had been in existence prior to His time. Christ introduced a different type of discipleship.

\section{Disciples in the Ancient World}

People who were deemed to have extraordinary wisdom had followers known as disciples. There were notable teachers of Greek descent who were considered masters in their various fields including philosophy. These celebrated teachers like Pythagoras and others owned disciples. ${ }^{1}$ Paul met with some of their followers at Athens (Acts 17:1634). There were disciples in religious circles, too. John the Baptist had disciples (Matt 9:14; 11:2; John 1:35-37). The Pharisees claimed to be disciples of Moses (John 9:28). The Pharisees had their own disciples, too (Mark 2:18; Luke 5:33).

However, as a teacher, Jesus had no equal. He was "the greatest Teacher the world has ever known." ${ }^{2}$ He taught with authority (Matt 7:29). He made Scriptures plain to His disciples (Matt 13:36; Luke 8:9). He was relevant to His audiences.

\section{Meaning and Implications of Mathetes}

The word disciple is one of those words pregnant with meaning. Disciple is an anglicized form of a Latin word discipilus ${ }^{3}$ which means a learner. Among the Greeks,

${ }^{1}$ Michael J. Wilkins, Following the Master: A Biblical Theology of Discipleship (Grand Rapids, MI: Zondervan Publishing House, 1992), 72.

${ }^{2}$ White, The Acts of the Apostles, 17.

${ }^{3}$ Encyclopedic Dictionary of Religion (1979), s.v. "Disciple." 
Herodotus is said to have casually used the word mathetes for the first time in his writings as early as the fifth century. ${ }^{1}$ With time, the Greeks used the word mathetes to designate "master-disciple relationships." In Greek literature, as in Latin, mathetes meant a learner, disciple, pupil, or an apprentice depending on the context. ${ }^{3}$

Sylvia Collinson informs us that as a model of teaching style, discipleship went beyond mere acquirement of factual information. ${ }^{4}$ Jesus shared with the disciples His very life. They learned from His lips and conduct. He spoke to them words of life (John 6:63). He was their role model. His impact on the disciples became very clear after Pentecost. The people noticed that the lives of the disciples had been transformed (Acts $4: 13)$.

The word mathetes "always implies the existence of a personal attachment which shapes the whole life of the one described as mathetes and which in its particularity, leaves no doubt as to who is the formative power." Discipleship reproduces one's faith over and over in other lives. ${ }^{6}$ Jesus was well aware that systematic discipleship would impact the mission now left with the church. The effectiveness of disciple-making

${ }^{1}$ Wilkins, Following the Master, 72.

${ }^{2}$ Ibid., 73.

${ }^{3}$ Ibid., 72.

${ }^{4}$ Sylvia Collinson, Making Disciples (Carlisle, UK: Paternoster Publishing, 2004), 24.

${ }^{5}$ Gerhard Kittel, "mathetes," Theological Dictionary of the New Testament, ed. and trans. Geoffrey Bromiley (Grand Rapids, MI: Eerdmans, 1967), 4:441.

${ }^{6}$ Ronald Warren Kincaid, "The Missing Ingredient in Christian Maturity: A Call to Church-Centered Evangelism" (D.Min. diss., Fuller Theological Seminary, 1989), 20. 
strategy is in the multiplication of the changed lives. Those who have experienced the transformation can hardly keep quiet. By virtue of being disciples, they find themselves duplicating their faith when they share their experiences. The cycle goes on and on until the Great Commission is accomplished.

Joel Green and Max Turner make a point worth mentioning that sometimes disciples of certain teachers come long after the death of their acclaimed teacher. ${ }^{1}$ This is true of Christ's disciples. He continues to attract followers after His death, resurrection, and even in His visible absence. He draws people to Himself when uplifted by His dịsciples (John 12:32).

Jesus laid the foundation for revolutionary discipleship in the New Testament. The Master teacher used well-known methods of teaching to disciple the people who "differed widely in habits and disposition."” This timeless strategy can work with any diversified group of people in any place, circumstances, and at any given time.

\section{Roots of Discipleship}

Walter Elwell's biblical perspective is that discipleship in the New Testament has its strong link and roots in the Old Testament, especially if one looks at the idea of God's call of Israel (Exod 19:5-6) to make Israel His peculiar treasure. ${ }^{3}$ Discipleship starts with God's call. The call comes with a specific mission to accomplish for Him. Nobody is

${ }^{1}$ Joel B. Green and Max Turner, eds. Jesus of Nazareth: Lord and Christ (Grand Rapids, MI: William B. Eerdmans Publishing Company, 1994), 112.

${ }^{2}$ White, The Desire of Ages, 296.

${ }^{3}$ Baker Encyclopedia of the Bible, 1988 ed., s.v. "Disciple." 
pressurized to accept the call. Acceptance is voluntary. Persons in the Old and New Testaments felt too small for God's call. They regarded the call as an honor.

In the Old Testament, discipleship was limited in scope, frequency, and in purpose. The Hebrew word talmidh is the Old Testament equivalency of the New Testament Greek word for disciple, mathetes. ${ }^{1}$ It gives an idea of a pupil-teacher relationship. This type of relationship is different in the present pupil-teacher structure. The ancient practice was usually one-on-one tutorship. Not everybody could afford this. It was for the rich people or the royal families. They employed the best teachers to tutor their children in the home. God uses the best methods to reach people at different times and circumstances.

Approach to Missions: Centripetal and Centrifugal

Russell Staples says "centripetal" and "centrifugal" are two different approaches to mission. ${ }^{2}$ In the Old Testament, mission was largely centripetal. In this approach, mission was not seen as a movement. There was a central place which had as it were some drawing mechanism. In this case, the force was the glory of Jerusalem. The magnificent temple, priestly services, sacrifices, and the one true powerful God were attracting people. The Queen of Sheba came to Jerusalem for Solomon's wisdom (1 Kgs 10:1-13). The Babylonian envoys traveled to inquire about Hezekiah's healing (2 Chr 32:31). The sign of Hezekiah's healing was too extraordinary to ignore. These heathen ambassadors came "to learn, if possible, more of the God who was able to perform so

${ }^{1}$ Wilkins, Following the Master, 54-55.

${ }^{2}$ Russell L. Staples, Community of Faith (Hagerstown, MD: Review and Herald Publishing Association, 1999), 104-105. 
great a wonder." Jesus reversed the approach during His ministry when He gave the marching orders in the Gospel Commission.

In the New Testament, mission is primarily centrifugal, going or sending out. ${ }^{2}$ Jesus sent the disciples into the world (Matt 28:19-20). He prayed for their protection in the world but not their removal from the world (John 17:15). The work of the Christian disciples is in the world. However, comprehensively, mission consists of both attracting in and going out. ${ }^{3}$ Christ's command is to go not merely to reach but to "make disciples." The emphasis falls on the making which involves a process.

Christian disciples are compared to salt and lights of the world (Matt 5:13-16). Salt saturates, gives taste, and preserves. Christ's disciples have the same infectious effect on the lives of other people. Their connection with Jesus makes them useful and effective as salt and lights. The disciples have a latitude for a holistic growth in both vertical and horizontal relationships. ${ }^{4}$ It is of no wonder that "discipleship results in mission." ${ }^{15}$ The sense of mission creates a natural desire to share the good news with others and to see them grow to maturity. Growth to maturity shows itself through discipleship.

${ }^{1}$ Ellen G. White, Prophets and Kings (Boise, ID: Pacific Press Publishing Association, 1943), 344.

${ }^{2}$ Staples, 105 .

${ }^{3}$ Ibid., 101.

${ }^{4}$ William J. Larkin, Jr. and Joel F. Williams, eds., Mission in the New Testament (Maryknoll, NY: Orbis Books, 2003), 130.

${ }^{5}$ Collinson, 202. 
Jesus can reach the nations without the aid of human beings. It is out of love that He invites people into partnership with Him. He loves people with no ordinary love (Jer 31:3; John 15:13). In fact, love is one of God's attributes (Exod 34:6; 1 John 4:8). The human messengers plant and water but God causes the miracle of growth (1 Cor 3:6). Invitation to participate is really a way to bless mankind.

Ellen White says the Savior involves people that they may develop Christ-like character. It is also by participating that people can experience Christ's joy, "joy of seeing souls redeemed by His sacrifice. ${ }^{11}$ Human involvement is nothing but, at best, God's grace. The seventy-two disciples (Luke 10:1) sent on a mission, not confined to the house of Israel (Matt 10:6) came back rejoicing because they experienced Christ's intended joy (Luke 10:17). The Master challenged them to rejoice beyond temporary success. The disciples' greatest joy is to have their names written in the books of heaven (Luke 10:20). The whole aim of discipleship is salvation through the name of Jesus whereby sinners are saved (Acts 4:12).

Many Christians suffer for not being involved in the life of the church. Ken McFarland compares such people to thousands of spectators who pack American stadiums every week to watch few people on the field who desperately need rest. ${ }^{2}$ The spectators hardly benefit. Spectators are oftentimes very critical of the participants. They grow cold and become lukewarm as Laodicea (Rev 3:15-16). Some backslide in their walk with Christ. On the other hand, disciple-making enhances a steady growth in one's

${ }^{1}$ White, The Desire of Ages, 142.

${ }^{2}$ Ken McFarland, Christianity Is Not a Spectator Sport: God Needs Players, Not Cheerleaders (Fall Brook, CA: Hart Research Center, 1993), 6. 
Christian life (Heb 6:1; Eph 4:13-15). It also aids in retention of church membership. Mature disciples develop a sense of belonging in the church family. They value their walk and intimate relationship with the Lord.

The Scriptures provide a firm biblical and theological basis for discipleship. The Old Testament is the bedrock of discipleship. God's concern for the nations and sending Abraham on a mission to reach them (Gen 12) is the same concern Jesus shows in the New Testament. He sends the disciples of all ages to "go and make disciples of all nations" (Matt 28:19). The doctrine of the priesthood of all believers has its birth in the Old Testament Scriptures (Exod 19:5-6). Again, it is re-echoed throughout the New Testament (1 Pet 2:9).

God will not rest until He accomplishes His mission to restore the lost and to bring the light of "salvation to the ends of the earth" (Isa 49:6). Jostein Adna and Hans Kvalbein see beyond restoration of Israel. For them, "the promise of God's reign is not simply the restoration of the preserved of Israel, but the renewal of the vocation of Israel to be a light to the nations to the end of the earth." The prophets had declared that Israel was to do her mission centripetally from Jerusalem (Ps 96:3; Isa 40:9; Zech 8:23). This command which was to Israel then, is "expanded universally and is now valid for all peoples." It is therefore beyond a shadow of doubt that the Old Testament Scriptures provide a biblical foundation for understanding and developing a systematic discipleship

${ }^{1}$ Jostein Adna and Hans Kvalbein, eds., The Mission of the Early Church to Jews and Gentiles (Tubingen, Germany: Mohr Siebeck, 2000), 109.

${ }^{2}$ Tbid., 17. 
strategy. Contemporary disciples have been given the mandate to continue with the challenge of God's mission "to the very end of the age" (Matt 28:20).

\section{Old Testament Models}

God had a way of providing strong leadership among His chosen people, Israel. Wilkins agrees that there were several service-oriented relationships in the Old Testament that could easily be called "discipleship relationships." Some of the leaders were discipled by their predecessors. In this way, they were better prepared for their work. In fact, in some cases, they were even more successful than their predecessors.

Although the word disciple is not used in reference to the intern leaders, yet there is a principle in place. They followed discipling procedures. There was a learner and a teacher. The two were not equals per se. They lived and traveled together. They became close friends. This was a form of discipleship. It served its intended purpose.

\section{Moses and Joshua}

God called Moses in a dramatic setting of a burning bush (Exod 3:1-22). He sent him on a specific mission to go and lead the children of Israel out of Egypt (Exod 3:10). As in all divine commissions, Moses was promised God's help with his speech (Exod 4:12). In addition, God Himself was going to deal with the hard-hearted Pharaoh (Exod 3:19-20). In this case, Moses was simply a visible agent through whom God worked.

As soon as the mission was accomplished, the liberated Israelites started complaining. They grumbled over Pharaoh's army following them (Exod 14:10-12), bitter water at Marah and Elim (Exod 15:22-24), and for lack of Egyptian flesh (Exod

${ }^{1}$ Wilkins, Following the Master, 61. 
16:1-3). Moses was kept busy all day long and still had a backlog of cases to sort out. This frustrated him as well as the people whose cases were pending. There was need for an effective leadership style. The amount of work called for a strategic planning.

Moses' leadership took a sudden turn when Jethro, his father-in-law, suggested a solution to the whole problem. He advised Moses to select a team of assistants composed of "capable men from all the people" (Exod 18:21). Moses oriented, taught, and modeled for them (Exod 18:20). He nurtured them like a parent. After training, he gave them authority to act on minor cases (Exod 18:22). They also helped him with the teaching of God's law. This made the work manageable. Moses had time to rest and for his family. He reduced his stress levels. Most importantly, the people were better served. At the same time, Moses was able to develop future skilled leaders for the nation.

The name of Joshua is closely associated with Moses. To begin with, Moses changed his name from Hoshea to Joshua (Num 13:8, 16). This young Ephraimite, son of Nun, was known as "Moses' aide since youth" (Num 11:28). In other words, he was Moses' disciple. He received training in all areas of leadership including the military. Joshua commanded the Israel army that defeated the Amalekites (Exod 17:9-14).

Joshua's tutorship was gradual but thorough. It was a real a mentoring process. He accompanied Moses to Mount Sinai to receive the commandments while Aaron, Hur, and the rest of the elders remained behind with the people in the camp (Exod 24:13, 14). Joshua displayed his loyalty and leadership skills when he and Caleb gave a positive report of their spying mission in Canaan contrary to the ten spies (Num 13:5-9). Ellen White sheds more light about Joshua's character and responsibility. She states that, 
"during the sojourn in the wilderness he had acted as a prime minister to Moses, and by his quiet, unpretending fidelity, his steadfastness when others wavered, his firmness to maintain the truth in the midst of danger, he had given evidence of his fitness to succeed Moses, even before he was called to the position by the voice of God."'

Mentoring another person was not man's invention. It was God's way. The Lord showed His approval when He told Moses to encourage Joshua, his assistant since he was the one to lead Israel into Canaan (Deut 1:38). Moses told Joshua that continued success and prosperity depended on his meditation on the "Book of the Law" (Josh 1:8, 9). God used mentoring to prepare and develop His messengers for service.

Moses' next step was the ordination of his assistant (Num 27:18). This was followed by an inauguration ceremony. Moses gave charge to the young successor before the whole assembly of Israel (Deut 31:7, 8). This was a good start for the young leader. People knew for sure who their leader was. They listened to Joshua (Deut 34:9). They accepted the new leader without reservation. Moses was possibly the happiest to see his intern fulfilling the purpose of discipling.

Public recognition for the newly coached disciple helps in several ways. It serves as an approval of one's calling. It lends importance to the ministry. It also serves as a reminder of one's commitment, especially so at some point when things become hard and one doubts if it is worth the trouble. Public recognition becomes a beacon of strength during such testing times.

${ }^{1}$ Ellen G. White, Patriachs and Prophets (Boise, ID: Pacific Press Publishing Association, 1958), 481-482. 
Discipleship preserves the master's legacy and passes on to others the cherished ideals, goals, and dreams. Joshua continued the legacy of Moses, the greatest prophet (Deut 34:10). This is one beauty of discipleship. Like his mentor, Joshua involved more people. He delegated responsibilities to the officers of the people (Josh 1:10-11). He sent spies "to look over the land" of Jericho (Josh 2:1). Joshua's style of leadership shows how much influence Moses had on his life. However, Joshua was discipled with his own identity. He had a different personality. He had unique God-given gifts. Discipleship dynamics may change from one person to another because there are no two people alike.

\section{Eli and Samuel}

Hannah named her son Samuel because he was God's answer to her prayer (1 Sam 1:20). His attachment to Eli is a clear case of discipling. The young boy came to be with Eli, the elderly high priest, at a very tender age. His mother brought him after he "was weaned" (1 Sam 1:24). According to the Jewish tradition, age twelve was considered "the dividing line between childhood and youth." He had a "special commission" when he was twelve years old. Samuel became Eli's disciple at the beginning of an important period, another segment of his life.

Samuel started his second phase of life as a learner, a disciple. He performed his temple duties "under Eli the priest" (1 Sam 2:11). With a wealth of experience, Eli was more qualified to help raise and train this young internee. Eli loved Samuel dearly and

${ }^{1}$ White, The Desire of Ages, 75.

2“Samuel," SDA Bible Commentary, ed., F. D. Nichol (Washington, DC: Review and Herald Publishing Association, 1976), 2:1010. 
they became best friends. ${ }^{1}$ These two people had a disciple-master relationship. It was Eli who taught Samuel how to discern and respond to God's voice (1 Sam 3). The young intern learned the lesson and responded when God called him again.

Eli assigned Samuel duties according to his ability. He realized that Samuel needed to mature. He needed gradual development. Every year saw Samuel with "more important trusts committed to him." ${ }^{2}$ This was discipleship at best. Samuel became an outstanding leader at a time of national crises. God's glory had departed and the ark was taken by the Philistines. This was compounded by the death of the high priest Eli and his two sons (1 Sam 4:17-22). Samuel filled in the gap and steered the nation through crisis. This is one classic example showing success and the impact of disciple-making strategy. Discipleship avoids vacuums created by an unforseen crisis. A trained disciple takes over and moves ahead with the work. Such a person assumes responsibility with the benefit of hands-on training.

Samuel worked patiently with the children of Israel including king Saul. He was humble and committed himself to teach Israel the good way (1 Sam 12:23). The people respected him. They felt very much attached to him. He became more influential than king Saul. ${ }^{3}$ In spite of their sin in asking for a king, Samuel promised not to cease praying for them (1 Sam 12:19-23). Samuel's leadership shows that discipleship pays.

${ }^{1}$ Ellen G. White, Sons and Daughters of God (Washington, DC: Review and Herald Publishing Association, 1983), 161.

${ }^{2}$ White, Patriachs and Prophets, 573.

${ }^{3}$ Ibid., 663. 


\section{Elijah-Elisha-Gehazi Ministry}

The prophet Elijah had a packed ministry. He prophesied of a severe famine to last for three and a half years and it happened (1 Kgs 17:1; Jas 5:17). During this time of famine, Elijah was miraculously fed by the ravens and the widow of Zarephath whose son he raised from death (1 Kgs 17). Again, it was Elijah who single-handedly challenged and slaughtered 450 prophets of Baal $(1 \mathrm{Kgs} 18: 19,40)$. He did extra-ordinary miracles. But his greatest contribution was not in these breath-taking miracles. It has to do with the investment of time he took to disciple Elisha. In this way, he expanded his ministry to outlive himself. It went beyond the years of his lifetime. Training others is a rewarding ministry. We learn from Elijah that "ministry comprehends far more than preaching the word. It means training young men as Elisha, taking them from their ordinary duties, and giving them responsibilities to bear in God's work--small responsibilities at first, and larger ones as they gain strength and experience."

Elijah anointed "Elisha son of Shaphat" who later succeeded him (1 Kgs 19:16). Elisha got the call and left his parents. Elijah sent him back but the call was too strong to resist (1 Kgs 19:20). Elisha slaughtered the plowing oxen and burned all farming equipment. Then he followed Elijah and "became his attendant" (1 Kgs 19:19-21). Thomas Brodie sees this move as "a form of apprenticeship with Elijah." He was Elijah's disciple until the day his master was taken to heaven in a chariot of fire ( $2 \mathrm{Kgs}$ 2:11). This event marked Elisha's graduation after display of commitment and loyalty.

${ }^{1}$ White, Prophets and Kings, 222.

${ }^{2}$ Thomas L. Brodie, The Crucial Bridge: The Elijah-Elisha Narrative As an Interpretive of Genesis-Kings and a Literary Model for the Gospels (Collegeville, MN: The Liturgical Press, 2000), 7. 
Elisha had been with Elijah all the time from the day he joined him in service. $\mathrm{He}$ observed the manner in which the older prophet worked and the secret of his success.

God plans ahead of time. He does not allow His work to suffer or run short of workers at any given time even due to death. A disciple-making strategy addresses such eventualities as well. Ellen White says, "When the Lord in His providence sees fit to remove from His work those to whom He has given wisdom, He helps and strengthens their successors, if they will look to Him for aid and will walk in His ways. They may be even wiser than their predecessors; for they may profit by their experience and learn wisdom from their mistakes."”

Elijah reproduced his faith and manner of working in Elisha whose apprenticeship came to fruition the day his master departed. ${ }^{2}$ A company of prophets from Jericho who witnessed Elijah's departure, testified saying, "The spirit of Elijah is resting on Elisha" (2 Kgs 2:15). How will he work without Elijah? Ellen White's observation is that "his association with Elijah, the greatest prophet since the days of Moses, prepared him for the work that he was soon to take up alone." ${ }^{\prime 3}$ The system was already in place. Elisha took his position of leadership with smoothness. He had been thoroughly prepared.

\section{Character and Legacy of a Disciple}

Elisha continued discipleship legacy by passing on to someone what he had learned from Elijah. His servant named Gehazi was the next to benefit $(2 \mathrm{Kgs} 4: 12,26)$.

\footnotetext{
${ }^{1}$ White, Prophets and Kings, 228.

${ }^{2}$ Brodie, 7 .

${ }^{3}$ White, Prophets and Kings, 224.
} 
Gehazi was to Elisha what he himself had been to Elijah. Gehazi was Elisha's personal attendant. He was a learner, a student, and Elisha's disciple. He was in constant communication with the people on behalf of his master $(2 \mathrm{Kgs}, 4: 12,26 ; 8: 4)$. Unfortunately, like Judas, Gehazi proved to be greedy. He went after Naaman claiming that Elisha had changed his mind regarding acceptance of payment for the healing ( $2 \mathrm{Kgs}$ 5:22-27). This was pure falsehood. Naaman's leprosy came on him. This incident marked the end of his ministry. He did not prove to be a faithful disciple.

This tragic end is in no way a negative reflection on disciple-making strategy. Neither has it anything to do with Elisha, the master in this case. It simply exposes the weakness of character on the part of the pupil. The devil will do anything to disrupt the discipling process. The Christian warfare is not just against "flesh and blood, but against principalities, ... powers, ... spiritual hosts of wickedness in the heavenly places (Eph 6:12). After all, even Jesus Himself who had willed to "lose none" (John 6:39) lamented to have lost one (John 17:12). Our obligation is to do our part sincerely and leave the results with God. He will be responsible for the outcome.

\section{Discipleship Roots in the Old Testament}

The cited passages argue beyond doubt that discipling is firmly rooted in the Scriptures. The type and purpose of discipleship in the Old Testament is different from the one Jesus introduced in the New Testament as a strategy for regaining the world. However, the principle remains the same because the word disciple gives an idea of "total attachment to someone"1 whose teachings one follows and spreads. Those assuming

${ }^{1}$ Carlos G. Martin, Turning the World Upside Down (Nampa, ID: Pacific Press Publishing Association, 2000), 11.. 
leadership roles in the Old Testament were attached to their predecessors as long as life permitted in a disciple-master relationship.

The goal of discipleship in the Old Testament was the continuity of God-fearing leadership to the nation of Israel. With such leadership, the people kept the covenant, remained committed, and obedient to the one true God, their Creator. The learners who imitated their masters discharged their duties with much success.

\section{The New Testament}

In the New Testament, Jesus continued and brought revolution to a practice which in the Old Testament was basically used to prepare and maintain leadership for the chosen nation of Israel. Now the system became a strategy for multiplying workers to saturate the world with the gospel. Disciples are obliged to become like their master. They spread their master's teachings and lifestyle. ${ }^{1}$ In this way, they continue discipling for the master.

Jesus recruited and thoroughly trained twelve men for the leadership of His church that would affect the whole world. This core group of twelve became His disciples and an integral part of His mission. He involved them in His ministry during their training. One example was during the feeding of the five thousand. They organized the multitude into small groups and served them (Mark 5:39-42). These were earmarked "to be the world's teachers." ${ }^{2}$ Christ trained and educated them so they would in turn

\footnotetext{
${ }^{1}$ Ruthven J. Roy, "Not Just Membership: Called to Discipleship," Ministry, June, 2004, 17.

${ }^{2}$ Ellen G. White, Education (Mountain View, CA: Pacific Press Publishing Association, 1952), 85.
} 
"educate others and send them out with the gospel."1 Training and sending out is an ongoing activity of discipleship.

The twelve disciples were distinct from the masses (Luke 6:17; 19:37). They left behind their families and possessions in order to follow Jesus wherever He went. They were His friends (John 15:15). Therefore, they became the "recipients of His most frequent careful instruction."2 Their work was to assist Him to accomplish His mission. ${ }^{3}$ They were to pass on to others whatever they learned from the Master teacher.

The Great Commission marked the official end of directing a discipling process by Jesus. The ministry would continue but under the Holy Spirit (John 14:26). The risen Savior commanded all His disciples to the end of time to be busy with disciple-making. Thus, Christ's original disciples, the apostle Paul, Barnabas, and the early church took it seriously. As a result, the apostle Paul was able to say that the gospel was "proclaimed to every creature under heaven" in the then world ( $\mathrm{Col} \mathrm{1:23).}$

The twenty-first century church needs to revive the disciple-making strategy. The church must heed the call to rise to the occasion. Until that is done, according to McFarland, the church continues to be "a sleeping giant that needs to be roused, motivated, mobilized, energized." ${ }^{\wedge}$ This being the case, the urgent need is for disciplemaking minded leadership to stir the church into action. In most cases, purpose-driven

${ }^{1}$ White, The Acts of the Apostles, 17.

${ }^{2}$ White, Education, 86 .

${ }^{3}$ Donald McGavran and Win Arn, Back to the Basics in Church Growth (Wheaton, IL: Tyndale House Publishers Inc., 1981), 106.

${ }^{4} \mathrm{McFarland}, 13$. 
and visionary church administrators have the capability to set the whole church on fire for the Lord's Great Commission.

Jesus’ Disciple-Making Ministry

Jesus employed the disciple-making strategy to lay the foundation for accomplishing His mission on earth. At the very beginning of His public ministry, He personally chose His disciples (John 15:16). He picked men from the ordinary and marginalized groups of people. ${ }^{1}$ This was a reverse of the custom of the day in which the pupils chose their master. ${ }^{2}$ Although He chose them, the disciples were free to choose to follow Him or not (John 6:60-70). Other disciples, attached to human masters, aimed at becoming masters themselves. It is not the case with Christ's disciples. They do not detach themselves from Jesus. He continues to be their Lord and Master. He even forbade them from calling one another Rabbi or Master (Matt 23:8).

Again, unlike other disciples in the ancient world, Christ's disciples would not be above their leader, neither would they get disciples for themselves. ${ }^{3}$ In fact, Christ told His disciples that "no servant is greater than his master, nor is a messenger greater than the one who sent him" (John 13:16). The disciples came "into a community relationship centered on Jesus but in company with one another." ${ }^{4}$ He called them and they had a

${ }^{1}$ Thomas H. Groome, Sharing Faith: A Comprehensive Approach to Religious Education and Pastoral Ministry (New York, NY: HarperCollins Publishers, 1991), 303.

${ }^{2}$ Ibid.

${ }^{3}$ Collinson, 46 .

${ }^{4}$ Ibid., 48 . 
common bond in Jesus. Christ did not concern Himself with what programs to reach the world "but with men whom the multitudes would follow.""

Coleman writes that the principle of "selectivity and concentration" which Jesus used brings results ${ }^{2}$ wherever it is used. The communists employed it to spread their philosophy and they made a great impact on the whole world. ${ }^{3}$ The principle works wonders without regard to the user or purpose for which it is employed. Coleman is also on target to say that "a few people so dedicated in time will shake the world for God."4 After Pentecost, the disciples defied strict orders not to teach. Although small in number, it is amazing that they filled Jerusalem with their teachings (Acts 5:28). This small number of disciples handed over the responsibility of food distribution to the deacons and gave themselves fully to teaching the word. This focused ministry resulted into a rapid increase of disciples and priests in Jerusalem (Acts 6:1-7). Even the enemies of the gospel admitted that Paul and Silas had "turned the world upside down" (Acts 17:6 NKJV). A few people spurred by the Holy Spirit were able to reach "all the Jews and the Greeks who lived in the province of Asia" (Acts 19:10). Individuals can have such an influence. This can be duplicated again. Ellen White wrote, "One soul won to Christ will be instrumental in winning others, and there will be an ever-increasing result of blessing

'Coleman, The Master Plan of Evangelism, 21.

${ }^{2}$ Ibid., 35.

${ }^{3}$ Ibid.

${ }^{4}$ Ibid., 75. 
and salvation." It is therefore no wonder that a handful of disciples had such a force to impact the whole world.

From the human standpoint, one could justifiably say that Jesus selected people who were unpromising. They were not the cream of the society. However, time and time again, humankind is reminded that "the foolishness of God is wiser than man's wisdom" (1 Cor 1:25). As Pastor Welford Katundu often said, "God looks for availability and not ability."2 One would be interested to know how Jesus made simple fishermen and tax collectors into such reputable disciples. What about His curriculum? How does one go about discipling those who have willingly responded to the discipleship call? What lessons can one learn from Jesus' method of discipling?

\section{Christ's Actual Disciple-Making Process}

1. Teaching and learning. Choosing the disciples was only a starting point. Jesus called the disciples individually and promised to "make them fishers of men" (Matt 4:19). There was more in making them into fishers of men. According to Collinson, teaching and learning were the two predominant activities between Jesus and the disciples. ${ }^{3}$ He taught them in simple language, gave them "direct instructions," used "appropriate illustrations" usually from nature, and charmed His hearers with His

'Ellen G. White, Gospel Workers (Washington, DC: Review and Herald Publishing Association, 1915), 184.

${ }^{2}$ Welford W. Katundu, a humble and committed MU Ministerial Secretary, used to say that God gives ability to match the task He assigns to those who make themselves available to Him. Therefore, the Lord looks for availability and not ability.

${ }^{3}$ Collinson, 32 . 
"sympathetic and cheerful" words. ${ }^{1}$ Christ touched and led His disciples from one step to the next in keeping with their readiness. ${ }^{2}$ The disciples' duty was to learn from Jesus.

2. God's Word. The word of God was the subject of His teaching. ${ }^{3}$ Jesus realized that the word of God gives "a nobility of character, and a stability of purpose rarely seen in these times." God declared that His word was "like fire, ... and like a hammer that breaks a rock in pieces" (Jer 23:29). The God-breathed Scripture is "useful for teaching, rebuking, correcting and training in righteousness, so that the man of God may be equipped for every good work" (2 Tim 3:16-17).

3. Informal situations. Israel parents were told to teach their children at all times (Deut 6:7-9). With Jesus, teaching occurred in "informal situations," in conversations, or in response to questions. ${ }^{5}$ In other words, there was no set time for teaching. They did not have a structured program with a classroom and a timetable. Teaching took place anywhere and at any time. The disciples did not operate like robots. They were free thinkers. They faced life like anybody else. Success was not automatic.

'Ellen G. White, The Ministry of Healing (Mountain View, CA: Pacific Press Publishing Association, 1942), 24.

${ }^{2}$ Kenneth O. Gangel and James C. Wilhoit, eds., The Christian Educator's Handbook on Adult Education (Wheaton, IL: Victor Books, 1993), 17.

${ }^{3}$ Ibid., 21.

${ }^{4}$ Ellen G. White, Steps to Christ (Mountain View, CA: Pacific Press Publishing Association, 1956), 90.

${ }^{5}$ Collinson, 35 . 
4. Freedom to fail. Jesus allowed His disciples freedom to fail. ${ }^{1}$ Their faith was put to test when faced with the storm on the sea (Mark 4:40). They panicked and were restless. They were challenged by the demon-possessed boy while Christ was on the mount of transfiguration (Matt 17:14-17) and in many other incidents. As a teacher, Jesus wished them every success. Thus, He rebuked them for having little faith (Matt $8: 26 ; 14: 31 ; 16: 8,20)$. All this was done in and out of love (Job 5:17; Rev 3:19). In spite of their failures, Jesus never considered them hopeless. ${ }^{2}$ He saw hidden potential in everyone of the disciples. The Lord remained optimistic about His disciples thereby inspiring their hope. He looked at their failures as a call for further private instructions.

5. Reflection on failures in private. The Savior gave them time to reflect on their failures and to ask questions when they were by themselves in private places. After their disastrous ministry to the demon-possessed boy, they wanted to know why they could not drive it out (Mark 9:28). Christ capitalized on such failing moments. The Master disciple maker found an opportunity to introduce the need for prayer (Mark 9:29). Prayer was already a source of power for Jesus. He took time to be alone with God very early in the morning (Mark 1:35). The disciples saw the need after their disastrous performance.

6. Prayer life. The disciples needed to know that "prayer and faith will do what no power on earth can accomplish." ${ }^{\text {T }}$ The master teacher led His disciples into these threatening circumstances for their "personal growth in faith and trust in Jesus and the

${ }^{1}$ Ibid., 47.

${ }^{2}$ Ibid., 41.

${ }^{3}$ White, Ministry of Healing, 509. 
Father." All this was part of their discipling process. They were being equipped for spiritual warfare with the devil.

7. Reporting sessions. Another important element in their training was reporting and sharing their experiences with the rest of the disciples (Luke 9:10; 10:17-20). It was a high point. They learned from others, celebrated the results together, were encouraged, and inspired to do better next time. Reporting back is like an evaluation of progress made. It is a time to tie loose ends together. It avails an opportunity to thank God.

8. Therapeutic rest. Jesus and the disciples were kept very busy by the people.

In fact, they had no chance to eat (Mark 6:30). People were still coming and going, But now Christ longed for retirement, that He might be with His disciples; for He had much to say to them. In their work they had passed through the test of conflict, and had encountered opposition in various forms. Hitherto they had consulted Christ in everything; but for some time they had been alone, and at times they had been much troubled to know what to do. They had found much encouragement in their work; for Christ did not send them away without His Spirit, and by faith in Him they worked many miracles; but they needed now to feed on the Bread of Life. They needed to go to a place of retirement, where they could hold communion with Jesus and receive instruction for future work. ${ }^{2}$

Jesus knew the limits of His disciples. Like Elijah, they were men "just like us" (Jas 5:17). Realizing that by now they were probably physically and emotionally drained, He said to them, "Come with me by yourselves to a quiet place and get some rest" (Mark 6:31). "The rest which Christ and His disciples took was not self-indulgent rest."3 It was time to reflect on their past errors. They deliberated on ways to improve and "the

${ }^{1}$ Ibid., 56.

${ }^{2}$ White, The Desire of Ages, 360.

${ }^{3}$ Ibid., 361. 
possibility of bringing greater efficiency to the work."' Thus, besides resting, they learned, planned, and left the place more encouraged and inspired. They were ready to continue with more energy and renewed zeal.

Rest is an important element so often neglected by some zealous workers. It is therapeutic. Christ included it in the training of His disciples. There is always a danger of workers becoming workaholics and thinking that they are doing God a favor. Sometimes, God's workers feel guilty to go on annual leave. This is not necessary. Lamenting about her husband, Ellen White wrote, "My husband has had a zeal for God and for the truth, and at times this zeal has led him to overlabor to the injury of physical and mental strength." A committed worker may die prematurely due to work habits.

Some potential workers have experienced burn-outs, wrecked their marriages, and others have even died at the prime of their usefulness due to lack of balance in work habits. "Discipleship is not to exhaust people or fragment families because they spend too much time doing 'church work.' Discipleship is putting one's passions to work in ways that promote wellness and wholeness in the whole of life and in all arenas, in the church and the world, for the sake of Jesus."

${ }^{1}$ Ibid.

${ }^{2}$ Ellen G. White, Testimonies for the Church, vol. 3 (Boise, ID: Pacific Press Publishing Association, 1948), 88.

${ }^{3}$ Rick Barger, $A$ New and Right Spirit: Creating an Aunthentic Church in a Consumer Culture (Herndon, VA: The Alban Institute, 2005), 129. 
9. Individual molding. Jesus grew leaders for His church out of ordinary people. ${ }^{1}$ Roy says they had all the characteristics of a perfect formula for failure. ${ }^{2}$ Jesus knew each one of them intimately. He also knew their differences in character and temperament. He had to develop them individually and corporately. Barger reminds us that discipleship "cannot be left to technical approaches" or "one-size-fits-all formula."3. The making of a disciple has a recipe with different ingredients from person to person. People respond differently, however, the core basics remain unchanged.

10. Right conditions. Discipleship calls for right conditions on the ground. Harold Longenecker shares his observation that in discipleship, vibrant growth happens in a circle where people are "honest, warm, accepting, supportive, even confrontive and prayerful." Jesus created this atmosphere and environment in which the disciples felt secure and comfortable.

11. Openness. In preparing the disciples, Jesus taught them nothing but the truth. He prepared them to expect the worst. There were possibilities of rejection, imprisonment, hatred, and even death itself for His sake (Matt 10). At the same time, He promised them His victory (John 16:33). The human tendency is to hide possible hardships. There is need to avoid the extremes of painting a rosy picture or scaring the disciples. Jesus kept the balance to emulate.

${ }^{1}$ Harold L. Longenecker, Growing Leaders by Design (Grand Rapids, MI: Kregel Resources, 1995), 31.

${ }^{2}$ Roy, 17 .

${ }^{3}$ Barger, 128.

${ }^{4}$ Ibid., 50. 
12. Holy Spirit and unity. Again, Jesus did many things to train His disciples but, the training details were not written (John 20:30-31; 21:25). Their discipling was inadequate until He made them to understand their need for the power of the Holy Spirit and importance of unity among themselves (Acts 1:8; John 17). To safeguard this unity, Jesus had earlier given them a new commandment to "love one another" which was also the mark of identity for His disciples (John 13:34-35). They were to keep united, wait in Jerusalem for the Holy Spirit, so to be "clothed with power from on high" (Luke 24:49). In his book Beyond the Number Game, Gary Exman says, "The Holy Spirit is the power factor, the multiplying factor, in any movement of God."' $\mathrm{He}$ is the powerhouse for Christian disciples. Bob Moorhead adds that the church needs to be power conscious because its birth, growth, and conquest were all in power. ${ }^{2}$ Jesus gave the commission with "all power" (Matt 28:18 KJV). He still gives that power for molding the lives of His disciples. The end events of the world point to a need for much power. The end-time disciples have the assurance of that power. "The great work of the gospel is not to close with less manifestation of the power of God than marked its opening."3 People will experience irresistible power, deeper convictions of the Holy Spirit, and fearlessly defy 23.

${ }^{1}$ Gary W. Exman, Beyond the Numbers Game (Lima, OH: Fairway Press, 1997),

${ }^{2}$ Bob Moorhead, The Growth Factor (Joplin, MO: College Place Publishing Company, 1991), 14.

${ }^{3}$ Ellen G. White, The Great Controversy (Mountain View, CA: Pacific Press Publishing Association, 1950), 611. 
those they once feared to offend by their acceptance of the truth. ${ }^{1}$ Jesus prepared His disciples for this power.

In conclusion, there are no two-ways for making disciples. Jesus gave a command and an example for disciple-making. The divine method is to recruit, teach, baptize, and mentor until the workers are able to lead other souls to Christ. Asa Boyd Luter observed that the Great Commission which has a "profound simplicity of the Risen Lord's prescription for making disciples until the end of the age must be accepted on its own terms." The disciples are to obey everything Jesus has commanded them. Only then can they claim His promises.

\section{Discipling Family Members and Associates}

Another strategy within a strategy was to start making disciples right there in Jerusalem (Acts 1:8). The disciples were in this city. They had to start the work immediately. All the events connected with Christ's crucifixion took place during the Passover Feast in Jerusalem. People from various provinces had witnessed the events. What does this teach us? "We must reach the entire world, including where we live."

John the Baptist called the attention of his disciples to the "Lamb of God" (John 1:29). The first disciples recruited friends and relatives at the very beginning of Christ's ministry. The disciples asked Jesus where He stayed. He invited them to come and see

${ }^{1}$ Ibid., 612.

${ }^{2}$ Asa Boyd Luter, Jr., "A New Testament Theology of Discipling" (Th.D. diss., Dallas Theological Seminary, 1985), 61.

${ }^{3}$ Crawford W. Loritts, A Passionate Commitment: Recapturing Your Sense of Purpose (San Bernadino, CA: Here's Life Publishers, Inc., 1989), 77. 
for themselves His place of abode (John 1:39). They liked whatever they saw. Andrew brought his brother whom Jesus renamed "Cephas" meaning "Peter" (John 1:41-42).

Philip came with Nathanael (John 1:44-46). The first disciples called those they cared about. Thus, Collinson concludes that discipleship starts with a witness about Jesus, followed by four actions namely, "follow, seek, stay, and see."

Today, the commission puts the disciples in different circumstances. Their assignment is not limited to friends and family members. They have to cross cultural and racial borders. The disciples are challenged to think, plan, and act globally.

\section{Apostle Paul}

Paul was not one of the twelve disciples of Jesus. However, he introduces himself in most of his letters as an apostle (Rom 1:1; 1 Cor 1:1; Gal 1:1; Eph 1:1; Col 1:1; 1 Tim 1:1; Titus 1:1). Christ called him for a specific mission to the Gentiles (Acts 9:4-15). To begin with, he came to Antioch at Barnabas' invitation (Acts 11:25-26). Later on, Paul and Barnabas traveled with John Mark as a helper on their second missionary journey (Acts $12: 25 ; 13: 5)$. He also labored with Silas and Timothy (2 Cor 1:19). Again, at Corinth, Paul became co-workers with his fellow tentmaker hosts Aquila and Priscilla (Acts 18:1-3, 18-19). Paul was a disciple maker and a team player.

\section{Aquila and Priscilla}

Paul's stay with Aquila and Priscilla stirred the couple to action. Their deep devotion to Christ had to be expressed. These ordinary people demonstrated their spiritual maturity when they taught and discipled Apollos at Ephesus (Acts 18:24-28).

${ }^{1}$ Collinson, 81. 
"God often uses the simplest means to accomplish the greatest results." Apollos became a strong advocate for Christ (Acts 18:27-28). He was the couple's disciple.

\section{Timothy and Titus}

Timothy and Titus were also among Paul's disciples. He calls Titus, "my true son in our common faith" (Titus 1:4). He also refers to Timothy as "his true son in the faith" (1 Tim 1:2). These two young men were special to Paul. They were his young friends and fellow colleagues in the faith and ministry. They had a disciple-master relationship.

Writing about Timothy, Ellen White's insight is that the young man "longed to share the apostle's labors by assisting as the way might open"2 Paul chose him as a missionary companion because of his faithfulness, steadfastness, and truthfulness. ${ }^{3}$ As a young ministerial intern under Paul, he accompanied the apostle on his second missionary journey (Acts 16:3-5). "The great apostle often drew the younger disciple out, questioning him in regard to Scripture history, ... he carefully taught him how to do successful work."4 Paul employed the same methods to disciple Timothy as Jesus used to prepare His disciples.

Timothy completed his internship. It was now time for him to be on his own. Therefore, Paul gave him a ministerial charge. "The things you heard me say in the presence of many witnesses entrust to reliable men who will also be qualified to teach

${ }^{1}$ White, The Desire of Ages, 822.

${ }^{2}$ White, Acts of the Apostles, 203.

${ }^{3}$ Ibid.

${ }^{4}$ Ibid., 204. 
others" (2 Tim 2:2). Logan sees Paul's admonition to Timothy as one of the clearest scriptural passages in the New Testament which mandates the church to "raise up and multiply qualified church leaders." This is what discipleship is all about. The young disciple needed to fulfill his biblical discipleship responsibility of reproducing more disciples. For someone to be considered a disciple, the person has to be actively engaged in the business of making other people disciples. ${ }^{2}$

Paul felt a weight of responsibility to teach others because whatever knowledge he gained was "entrusted" to him by God's command (Titus 1:3). It is with this background that he further urged Titus to teach Cretans and to appoint leaders (Titus 1:5). His teaching included the older women who would also "train the younger women" (Titus 2:1- 5). Discipleship knows no gender barrier.

Paul understood the concept of discipleship. It is a legacy passed from one generation to another. Paul's primary goal for Christians is to reach "maturity in Christ" (Col 1:28-29 NEB). This type of maturity means old members assuming spiritual parental responsibility of new converts. The new members grow to a point of becoming active discipling Christians. They, too, start to lead souls to Christ and guide them to maturity. The church becomes a center for mission evangelism. Such a church witnesses a balanced growth in numbers and in spirituality. There is real renewal among the members.

${ }^{1}$ Robert E. Logan and Neil Cole, Raising Leaders for the Harvest (Alta Loma, CA: CRM New Church Development, 1992), 1:8.

${ }^{2}$ Russell Burrill, Radical Disciples for Revolutionary Churches (Fallbrook, CA: Hart Research Center, 1996), 37. 
New believers need to be fed well and nurtured to full maturity in Christ. They need some parental understanding and patience as they grow. Like in the natural world, spiritual growth is spurred by activity. New believers should not be left idle. They are to be engaged. Discipling and equipping of the laity can be done simultaneously with their involvement in some work. ${ }^{1}$ Just as in the physical world in which little ones work according to their strength and ability, so it is in the spiritual world. The best way to disciple new believers is to assign them some work in proportion with their level of development. They can work along with the experienced members.

A discipleship strategy has a built-in element to prevent Christians from being “carried away by all kinds of strange teachings" (Heb 13:9). Christ's disciples are to be firmly established in the truth of their Lord. Jesus identifies His true disciples as those who practice and hold on to His teachings (John 8:31). Therefore, teaching what the Savior commanded is a major component in the coaching of disciples.

\section{Dimensions of Growth}

Scripture mentions several areas in need of growth. First, disciples need to grow in faith and in love (2 Thess 1:3). This growth does not come automatically. It is in the midst of a stiff controversy between good and evil as Paul experienced (Rom 7:21-25). Christ's disciples must make a complete surrender to the Lord of victory (1 Cor 15:57).

Second, the apostle Peter entreats disciples to "grow in grace and knowledge of our Lord" (2 Pet 3:18). Knowledge is power. Knowledgeable disciples tend to have a

'Darrell W. Robinson, Total Church Life: How to be a First Century Church (Nashville, TN: Broadman and Holman Publishers, 1997), 89. 
deep conviction and persuasion in the captain of their salvation (2 Tim 1:12). This growth ought to be reflected in the disciplines of Bible study, prayer, manner of conversations, and through the whole range of behavior. Discipleship is a relationship with the Lord Jesus.

The third dimension of growth affects life in its entirety. It is to be holistic in nature (Eph 4:13). Disciples attain all-round growth in Jesus by adding to their "faith goodness; and to goodness, knowledge; and to knowledge, self-control; and to selfcontrol, perseverance; and to perseverance, godliness; and to godliness, brotherly kindness; and to brotherly kindness, love" (2 Pet 1:5-7).

However, Christ's disciples demonstrate their unquestionable maturity when they follow the Savior in obedient service to Him. It means to actively engage themselves in the business of making disciples for the Lord Jesus. The ideal is to reach a "certain level of maturity so they can model Christianity and lead others to the same level of maturity."

Tom Sine says, "If the disciples are going to grow, they need to be given real responsibility, particularly in using their gifts in ministry."2 Ministry should be gift and need-oriented.

\section{Christian Stewardship}

God the Son created "everything in heaven and on earth" (Col 1:16). The Creator made man in-charge of His creation (Gen 1:26). Whatever a person acquires in this

${ }^{1}$ Gene A. Getz, The Walk: Growing into the Fullness of Christ (Nashville, TN: Broadman \& Holman Publishers, 2000), 203.

${ }^{2}$ Tom Sine, Taking Discipleship Seriously: A Radical Biblical Approach (Valley Forge, PA: Judson Press, 1993), 78. 
world belongs to Christ. Jesus gives life and ability to get wealth (Deut 8:18). People are but overseers and stewards of God's secrets (1 Cor 4:1-2, NEB). As Larry Burkett puts it, "He can choose to entrust us with as much or as little as He desires, but in no case will we ever take ownership." The Lord reserves ownership to Himself. Discipleship and Christian stewardship are closely related and are inseparable. The manner in which Christ's disciples handle this responsibility shows whether they are spiritually mature or not.

Comprehensively, Christian stewardship touches all areas of life. This includes time, health, talents, wealth, and other resources at man's disposal. True stewardship responsibility extends to fellow men and women (Gen 4:9). Disciples should be equally concerned with the salvation of other people as their own welfare. Christ's disciples have a sacred duty to reach others with the gospel and make them into disciples. In this way, they will have responded adequately to the apostle Peter's exhortation to serve others as "good stewards of the manifold grace of God" (1 Pet 4:10 KJV). Biblical stewardship deals with a proper attitude to all of God's creation and resources.

Many times making disciples demands use of both time and wealth. The training of disciples calls for time and money. In this case, one sure use of money will be towards the cost of literature. The Lord's design is for man to use the entrusted means for the building of His Kingdom. ${ }^{2}$ He is not interested in their money. After all, He already owns all the animals of the forest, cattle on the hills, gold and silver (Ps 50:10; Hag 2:8).

${ }^{1}$ Larry Burkett, The Word on Finances: Topical Scriptures and Commentary (Chicago, IL: Moody Press, 1994), 51.

${ }^{2}$ Ellen G. White, Counsels on Stewardship (Takoma Park, MD: Review and Herald Publishing Association, 1940), 35. 
Giving is a God-given opportunity for developing character. ${ }^{1}$ It is also a sign maturity in one's relationship with the Creator. ${ }^{2}$ Truly converted disciples understand, appreciate, and participate willingly in disciple-making with their God-given wealth.

Hence the issue of Christian stewardship has to do with character development of Christ's disciples. Barnett confirmed this fact when he wrote that God "is interested in what we are becoming."3 By reaching others with our means, we fulfill our stewardship and a major part of disciple-making duties. In this way, we become partners with God in making disciples even in the farthest parts of the world. At the same time, we increase the number of disciples who will become stewards to help with the cause of God on earth. ${ }^{4}$ Disciples' interests are with Jesus and that is where their earthly "treasure" goes (Matt 6:21). Ultimately, Christian stewardship is the acceptance of Christ's Lordship in one's life.

\section{Priesthood of All Believers}

The Bible teaches about the priesthood of all believers. God called Israel to be His "kingdom of priests" (Exod 19:6). The prophet Isaiah repeated the call: "You will be called priests of the Lord, you will be named ministers of our God" (Isa 61:6). In the New Testament, Peter calls Christians "a chosen people, a royal priesthood, a holy nation, a people belonging to God" (1 Pet 2:9). This theme of priestly people is also found in the

${ }^{1}$ Crown Financial Ministries, Biblical Financial Study: Small Groups Student Manual (Gainesville, GA: Crown Financial Ministries, Inc., 2003), 27.

${ }^{2}$ Jake Barnett, Wealth and Wisdom (Colorado Springs, CO: NavPress, 1987), 27. ${ }^{3}$ Ibid.

${ }^{4}$ White, Counsels on Stewardship, 35. 
last book of the Bible ( $\operatorname{Rev} 1: 6 ; 5: 10 ; 20: 6)$. The laity were active participants in the early church. No wonder that "the first Christian martyr was a layperson."1

Unfortunately, as David Bosch mentions, later there is a change in the Christian history when clergy assumed all the ecclesiastical power. This sad development was augmented by the system of the papacy and the priests. The clergy defined the laity as " immature, not come to age, and utterly dependent on the clergy in matters of religion."2 They were labeled non-professionals in church life. The laity became passive in church life. The system made them passive.

One of Martin Luther's contentious issues during the Reformation in the sixteenth century centered on the role of the laity in the church. For the German reformer, doing away with labels and "being one in Christ" (Gal 3:28) meant that through baptism, all believers were equal before God and had full right to a universal priesthood. ${ }^{3}$ Luther appealed to upholding the Bible teaching. As Cyril Eastwood says, "All Christians have God's Word and are under obligation to see its propagation."^4

Discipleship is in one sense the renewal of the biblical doctrine regarding the universal priesthood of all believers. As a matter of fact, Bosch views Christ's act to

${ }^{1}$ Walter B. Shurden, ed., Proclaiming the Baptist Vision: The Priesthood of All Believers (Macon, GA: Smyth and Helwys Publishing, Inc., 1993), 45.

${ }^{2}$ David J. Bosch, Transforming Mission: Paradigm Shifts in Theology of Mission (Maryknoll, NY: Orbis Books, 1996), 469.

${ }^{3}$ Hok, Gosta, "Luther's Doctrine of the Ministry," Scottish Journal 7, no. 1 (March 1954): 19.

${ }^{4}$ Cyril Eastwood, The Priesthood of All Believers: An Examination of the Doctrine from the Reformation to the Present Day (Minneapolis, MN: Augsburg Publishing House, 1962), 41. 
recruit ordinary people to be His disciples as in itself a mission statement that making disciples was a ministry for the whole people of God. ${ }^{1}$ God Himself showed nondiscriminatory acts in the outpouring of the Holy Spirit on all people in the upper room (Acts 2:1-4) and the giving of gifts to the whole church (1 Cor 12:27-31; Eph 4:8-13). These are further endorsements that every believer has a role in the Great Commission.

\section{Clergy and Laity: Partners in Discipleship}

Discipleship does not do away with the office of the clergy. It emphasizes a continued teaching ministry of the church by clergy. The clergy are enablers of the laity. Trained laity gain confidence to discharge their duties in disciple-making. The two parties work together in complementary roles. ${ }^{2}$ Lay persons are well placed "in all layers of the society" ${ }^{3}$ because they live and work out there. They are in constant touch with the people. The pastor's primary duty is to equip them for service. They need skills on how to approach people of diverse characters, occupations, and personalities. "Tact and good judgment increase the usefulness of a laborer a hundred-fold." A pastor can maximize the potential of the laity by training them for the Gospel Commission. A church with trained laity minimizes internal conflicts among the members. They are pre-occupied with the main business of the church which is disciple-making. If the members are left idle, the devil seems to be ready on hand to find something divisive for them.

${ }^{1}$ Bosch, 467.

${ }^{2}$ Robinson, 92 .

${ }^{3}$ Norman E. Thomas, Classic Texts in Mission and World Christianity (Maryknoll, NY: Orbis Books, 1995), 243.

${ }^{4}$ White, Gospel Workers, 119. 


\section{The Clergy and Specialized Lay Training}

Lay persons can be trained to work specifically with new members from other churches who are now cut off from their accustomed pastoral services. ${ }^{1}$ These members have unique challenges. They need to be encouraged and assisted to settle in this newly found faith and church. Spiritually mature old members who came from other churches may be among the right people for this ministry. The seasoned members can assist the new members by creating a genuine atmosphere of love and acceptance. If discipleship starts with public evangelistic meetings, it is better to teach the need for warmth and acceptance during ground preparation before commencing the meetings. The initiative starts with the pastor doing his or her biblical role to equip the laity of the church.

John Grys and Greg Schaller say that the pastor can be the "greatest barrier" in empowering lay persons. ${ }^{2}$ Some pastors feel insecure in their calling. This might stem from their own inadequate training. Multi-talented and better qualified lay persons are a threat to their position. This feeling of insecurity needs to be confronted by those who cherish it. It prevents pastors from realizing laity potential as well as their own.

Another group of pastors fail to delegate authority for fear that lay persons will be unsuccessful. The clergy with this thinking mode find it too much a risk to delegate. Margie Ulrich and the laity are saying, "The best gift a pastor will give is to trust that we will do a task successfully." ${ }^{3}$ Some lay persons go to an extent of thanking the pastor for

\footnotetext{
${ }^{1}$ White, Evangelism, 35.

${ }^{2}$ John Grys and Greg Schaller, "Growing a Healthy Church,” Ministry, March, 2001,11 .

${ }^{3}$ Margie Littel Ulrich, "Pastor as a Leader: Job Impossible," Ministry, JulyAugust, 2005, 73.
} 
involving them. ${ }^{1}$ They feel good to be recognized and to be given an opportunity to contribute to the life of their church. Involvement makes them feel wanted and valued. It boosts spiritual self-esteem.

Traditionally, the prevailing thinking in the church is that the laity assists the pastor. McFarland begs to disagree with this school of thought. He says by training the laity, the pastor is doing his work "to assist them in their work." In other words, it is their biblical role. They are co-workers with God just like their pastor.

According to George Knight, sometimes pastors have a faulty focus. "We need to focus on the fact that our goal is not to run a good business here on earth but to forward the mission of the church"3 This being the goal, Bosch warns against the temptation to make "mini-pastors"4 out of the laity. The church will always need the ministry of both the clergy and the laity. An attempt to try to extinguish any of the two militates against biblical understanding of their distinct roles in discipleship. Pastors ought to remember that the lay persons have their professions. The idea is to give them the needed skills and techniques to enable them to serve the church and communicate the gospel effectively in their places of work and in their community. "The Christianity that conquered the Roman Empire was not an affair of brilliant preachers addressing packed congregations ... when

'In 1985, I wrote to thank Mr. Wales Maganga of the Ndirande Church for his time and money to decorate a pulpit for a field-wide Sabbath in Blantyre. He in turn expressed his deepest gratitude for involving him and further offered his services whenever needed.

${ }^{2}$ McFarland, Christianity Is Not a Spectator Sport, 20.

${ }^{3}$ George R. Knight, "Knight's Law Applied to Church Leadership," Ministry, JulyAugust, 2005, 25.

${ }^{4}$ Bosch, 473. 
we try to picture how it was done, we seem to see domestic servants teaching Christ in and through their work, small shopkeepers through their trade, and so on, rather than eloquent propagandists swaying mass meetings of interested inquirers." This can be done again if the laity is equipped with special skills and techniques.

Therefore, the pastor who does not empower the laity for the mission focus and emphasis does a great harm to the ministry of that church. Such churches remain crippled. In a healthy church, "all are ministers with special gifts for ministry, and all ministries are essential for corporate service, growth, and unity in the church of Christ."” Any change in an organization, "nation, church, or ministry" has always started with the leader. ${ }^{3}$ The pastor is the key to sensitize, educate, train, and build the church to function as the body of Christ (1 Cor 12:27). Trained laity has the potential to once again take rightful places in the Great Commission.

\section{The Laity of the Church}

On the other hand, lay persons who listen to sermons every Sabbath but fail to put into practice what they hear, deteriorate in their spiritual life. ${ }^{4}$ As a result, conflicts and in-fighting in the church have become common features. The pastor is kept busy trying to put out fires set by the inactive members. The church dies spiritually. Ellen White's Press, 1959), 9.

'Douglas P. Blatherwick, A Layman Speaks (London, Great Britain: The Epworth

${ }^{2} J o e l$ Sarli, “The Ministry of Equipping," Ministry, April 1999, 21.

${ }^{3}$ Peter Scazzero and Warren Bird, The Emotionally Healthy Church: A Strategy for Discipleship That Actually Changes Lives (Grand Rapids, MI: Zondervan, 2003), 36.

${ }^{4}$ White, Testimonies to the Church, 6:425. 
counsel is very appropriate in such situations. "The best medicine you can give the church is not preaching or sermonizing, but planning work for them. If set to work, the despondent would soon forget their despondency, the weak would become strong, the ignorant intelligent, and all would be prepared to present the truth as it is in Jesus."'

The genius of a discipleship strategy lies in its training and mobilization of the laity into a formidable "kingdom of priests" on a divine mission to make disciples of all nations. The universal priesthood of all believers is in keeping with the "the biblical understanding of the role, responsibility, and authority of the pastor" as set forth in Scriptures. $^{2}$ It is one doctrine in need of revisitation and revolution.

The members have a high regard for the pastor who treats them not as spectators but as equal partners in disciple-making. The reality is that there is no pastor who has all the expertise to equip the members. A wise pastor will identify professionals within the congregation or arrange for guest speakers who have the necessary expertise to help train the laity in their ministries. ${ }^{3}$ Churches with trained laity free their pastors to concentrate on a discipleship strategy. These kinds of churches grow numerically with corresponding spiritual maturity.

Discipleship prepares one to serve ably in the priesthood of all believers. This helps to advance the Great Commission. When pastors train the laity to serve in the "universal priesthood of all believers," it is a clear declaration of a "come and see

${ }^{1}$ White, Evangelism, 356.

${ }^{2}$ Shurden, 132 .

${ }^{3}$ Harold R. Fray, Jr., Conflict and Change in the Church (Boston, MA: Pilgrim Press, 1969), 69. 
church."1 It is a beginning of a new era for the congregation. The church becomes an "equip and send church."2 It is a mission-minded church. The empowerment of the laity is part of the Gospel Commission for the purpose of "discipleship, delegation, and multiplication of leaders." It enables the laity to use their gifts in ministries within the body of Christ and a mission to the nations.

\section{Spiritual Gifts}

Discipleship is closely related to the study of spiritual gifts. The two are meant for service and they both contribute to the development of the body of Christ. It is critical for the church congregation to know about spiritual gifts (1 Cor 12:1) and as to how every member can effectively play his or her role in the Great Commission. ${ }^{4}$

God gives these spiritual gifts to His children through the Holy Spirit (Rom 12:4-8; 1 Cor 12:4-11; Eph 4:7-13). Bugbee defines spiritual gifts as: "Divine abilities distributed by the Holy Spirit to every believer according to God's design and grace for the common good of the body of Christ.", They are not meant for personal use and benefit. They are primarily given for service to benefit others (1 Pet 4:10). Further, according to Schwarz, spiritual gifts are not given as a reward for good behavior or steady

'David Pendleton, "How to Make Your Church Grow: David Pendleton Interviews Pastor Wayne Cordeiro," Ministry, March 2001, 14.

${ }^{2}$ Ibid.

${ }^{3}$ Grys and Schaller, Ministry, 11.

${ }^{4}$ Bruce Bugbee, What You Do Best in the Body of Christ (Grand Rapids, MI: Zondervan, 2005), 35.

${ }^{5}$ Ibid., 38. 
character. ${ }^{1}$ It is of little wonder that "spiritual gifts are made in the context of the body of Christ and its growth."2 The church is rich in spiritual gifts.

R. Wayne Jones sees a close connection between the activities of God's Spirit in the Old Testament and the giving of the spiritual gifts in the New Testament. ${ }^{3}$ The Spirit of God is very active beginning with creation itself (Gen 1:2). The same "Spirit of the Lord" came with power on Othniel, Gideon, and Samson and enabled them to accomplish extraordinary feats (Judg $3: 10-11 ; 6: 34 ; 14: 6 ; 15: 14)$. Saul received ecstatic power of the Spirit after Samuel anointed him to be the first king of Israel (1 Sam 10:10-11). He was an amazement to the people who saw him prophesying with the prophets. Saul's change "into a different person" and ability to prophesy was owed to "the Spirit of the Lord (1 Sam 10:6). However, the Spirit's activities in the Old Testament are seen to be temporal until the prophets began to focus towards the coming Messiah. ${ }^{4}$

The Holy Spirit has always been active ever since the creation of this world. The Old Testament prophets looked to the future when God's Spirit would forever abide with the Messiah. ${ }^{5}$ In the Messianic prophecy, Isaiah said, "The Spirit of the Lord shall rest upon him" (Isa 11:1-3). In other words, through the Messiah, the Spirit of the Lord

${ }^{1}$ Christian A Schwarz, The Three Colors of Ministry: A Trinitarian Approach to Identifying and Developing Your Spiritual Gifts (St. Charles, IL: ChurchSmart Resources, 2001), 43.

${ }^{2} \mathrm{Ibid}$.

${ }^{3}$ R. Wayne Jones, Using Spiritual Gifts (Nashville, TN: Broadman Press, 1985), 19.

${ }^{4}$ Ibid., 22.

${ }^{5}$ Ibid., 23. 
would come in a more permanent status. The coming Messiah would "bear the gifts of wisdom, counsel, and knowledge." This biblical concept of gifts in the Old Testament continues in the New Testament when God graces His children with spiritual gifts through the Holy Spirit (1 Cor 12:4-11).

According to the Pauline letters to the churches at Corinth and Ephesus, God has given every believer at least one spiritual gift (1 Cor 12:7; Eph 4:7). Some individuals may be "multi-gifted." Usually their gifts are in the same area. A person gifted in administration might have special abilities in leadership and discernment. Bugbee refers to such individuals as people with a "gift mix." 3 This does not make those individuals more important than the single-gifted. It simply increases their accountability and much will be required from them (Luke 12:48). There are variations of the gifts and degrees of giftedness. ${ }^{4}$ Schwarz gives a practical example of how different people might show a gift of evangelism in different ways and degrees. One might show it in preaching and another in personal conversation. These are two different individuals, with two different personalities. This same gift might come out in another person through writing evangelistic tracts while someone may show an extra ability in working with children. ${ }^{5}$

The gift may come either at one's physical or spiritual birth in the body of Christ. ${ }^{6}$

${ }^{1} \mathrm{Ibid}$.

${ }^{2}$ Tbid., 13.

${ }^{3}$ Bugbee, 51.

${ }^{4}$ Ibid., 46.

${ }^{5}$ Ibid.

${ }^{6}$ Jones, 10. 
Another writer goes further to describe the gifts as "original or acquired, natural or spiritual." Natural and spiritual gifts are not the same but they share similarities. Bugbee calls the gift connected with physical birth a "natural talent."" Natural gifts serve as indicators of God's grace to all people while spiritual gifts are given to those who experience a spiritual birth. ${ }^{3}$ "In becoming His disciples, we surrender ourselves to Him with all that we are and have. These gifts He returns to us purified and ennobled, to be used for His glory in blessing our fellow men." ${ }^{, 4}$ The Holy Spirit transforms ${ }^{5}$ and helps to acquire the gifts depending on the need. In this way, every member of the church "may act a part in the work of preparing a people for Christ's soon coming."

Another difference to be noted is between spiritual gifts and the "fruit of the Spirit" (Gal 5:22-26). We may consider the fruit of the Holy Spirit in terms of "being" qualities, while spiritual gifts are action "doing" qualities. ${ }^{7}$ They both come to us through the Holy Spirit. Therefore, the Holy Spirit gives and empowers the transformed believer to effectively use the gifts in making disciples for the kingdom of God.

'Ellen G. White, Christ's Object Lessons (Washington, DC: Review and Herald Publishing Association, 1941), 328.

${ }^{2}$ Bugbee, 52 .

${ }^{3}$ Ibid.

${ }^{4}$ White, Christ's Object Lessons, 328.

${ }^{5}$ Bugbee, 52.

${ }^{6}$ White, Gospel Workers, 481.

${ }^{7}$ Bugbee, 54. 
Gift discovery helps to know one's calling and ministry. ${ }^{1}$ People become aware of what God intends for them and their role in the Gospel Commission. It also helps the pastor, a key person, ${ }^{2}$ to strategically mobilize the believers into ministries matching their gift(s) and passion. Gift identification does not happen easily. It takes "prayer, study, experience, and reflection." ${ }^{3}$ Sometimes, it calls for other people to help confirm one's spiritual gift.

Rick Warren says the best way to discover a gift is to try several ministries and if they do not work well, quit and call them experiments until you find yours. ${ }^{4}$ Christopher Schalk advocates the concept of "gift counselors" in a local church. This person helps members with gift discovery. It could be someone with experience and expertise or one gifted in discernment. The laity is highly motivated when the church engages them in their gift-based ministries. The wise church leadership matches gifts with need-oriented ministries. The laity becomes more fruitful and experiences internal joy and satisfaction. ${ }^{6}$ It dawns on them that they are doing what God intended them to do. They are excited to

${ }^{1}$ Bruce Allen Storms, "A Program for the Discovery of Spiritual Gifts and Their Development in Lay Ministries" (D.Min. diss., Drew University, 1990), 44.

${ }^{2}$ C. Peter Wagner, Your Spiritual Gifts Can Help Your Church Grow (Ventura, CA: Regal Books, 1979), 138.

${ }^{3}$ Bugbee, 57.

${ }^{4}$ Rick Warren, The Purpose Driven Life: What on Earth Am I Here For? (Grand Rapids, MI: Zondervan, 2002), 251.

${ }^{5}$ Christopher Schalk, How to Use the 3 Colors of Ministry in a Mentoring Relationship (St. Charles, IL: ChurchSmart Resources, 2001), 9.

${ }^{6}$ Paul R. Ford, Unleash Your Church: A Comprehensive Strategy to Help People Discover and Use their Spiritual Gifts (St. Charles, IL: ChurchSmart Resources, 2002), 25. 
make a significant contribution to the life and ministry of the church. Ultimately, this pleases and glorifies God.

The study of spiritual gifts posits several challenges to the church. First, there is no one person who has all the gifts needed to develop a healthy church. Gifts are given to every individual. The first challenge is to discover and use them accordingly. If not used, the potential lies dormant or dies. Second, there is need for unity of the body. Unity makes it possible for people to employ their gifts towards the same goal.

Another area of challenge has to do with possible abuse of the gift. Some more gifted people become proud and fall into a temptation of looking down upon others. This was the case in the church at Rome. Paul warned the members not to think highly of themselves since they were like one body with many organs (Rom 12:3-8). These gifts make disciples inter-dependent of one another. There is no reason for boasting. This unchristian attitude offends other members and discourages them from developing theirs.

Discipleship in Malawi faces another theological challenge connected with these spiritual gifts. The Bible is clear that God has given every person, male and female, some unique gift (1 Cor 12:7; Eph 4:7). Some local church leaders, and maybe pastors, need to be thoroughly educated on this biblical and theological teaching about the operation and responsibility over the God-given spiritual gifts. There have been incidents where women have been denied opportunity to fully use their gifts in the church.

Nancy Hardesty argues that any attempt to discriminate people in the service of the church on the basis of gender amounts to "a form of blasphemy against the Holy 
Spirit." It is a serious charge against knowledgeable church leaders who were supposed to be equipping every member of the church regardless of gender. The practice is biblically, theologically, and ethically wrong. This stems from the traditional view of women and misunderstanding of Paul's writings that women are to keep silent in church (1 Cor 14:34; 1 Tim 2:11-12). This unjustified attitude towards female members goes against God's plan in every conceivable way. The disciple-making strategy in Malawi has to address this attitude against women.

These God-given hidden, potential skills are powerless in the absence of the Holy Spirit. $^{2}$ The Holy Spirit works with humble and teachable disciples as they use their gifts to bring other lives under the "Lordship and rule" of Jesus Christ. Paul confesses that it was Christ who accomplished through him all the success in his ministry to the Gentiles (Rom 15:18). Again, love is a binding factor for the disciples in the Gospel Commission. Without genuine agape love, all efforts even by the most gifted, amount to nothing ( 1 Cor 13:1-3).

When people do what they are comfortable with because of their gift, they seem to have a degree of endurance. Max Turner points out that spiritual gifts enabled the disciples to continue a "meaningful Christian existence." ${ }^{4}$ Hemphill goes further to say

'Nancy Hardesty, "Gifts," The Other Side (July-August, 1977) 40; quoted in C. Peter Wagner, Your Spiritual Gifts Can Help Your Church Grow (Ventura, CA: Regal Books, 1979), 41.

${ }^{2}$ White, Christ's Object Lessons, 328.

${ }^{3}$ Max Turner, The Holy Spirit and Spiritual Gifts Then and Now (Carlisle, UK: Paternoster Press, 1996), 352.

${ }^{4}$ Ibid. 
that these gifts are essential in making the life of the church. ${ }^{1}$ A gift-based discipleship strategy will mean more people serving with freedom and passion in the areas of their interest and special skills. This Bible-based strategy will bring back the spirit of the early church when the laity were daily ministering and winning souls. Ultimately, the gospel will reach all the nations of the world resulting into souls saved.

\section{The Great Commission}

The Great Gospel Commission runs through the sacred pages of the Bible. Even more is expected from this generation because it has received much more than those of the past. Others looked forward to the coming of the Messiah for the first time. Their generations had unfulfilled Messianic prophecies. It is not the case with us. Ours comes after the birth, ministry, death, and the resurrection of the Messiah. We have received His grace, the promise of the Holy Spirit, spiritual gifts, and the Gospel Commission given with Christ's full authority to make disciples of all the nations. It is an honor to participate. This is the work that "angels might envy." God gave this a sacred responsibility to sinners.

First, we need to understand the full scope of our task. Our mandate is to "make disciples of all nations" (Matt 28:19). Win and Charles Arn say: "The original Greek translation is to disciple panta ta ethne.... Ethne means the ethnic units of

${ }^{1}$ Hemphill, 74.

${ }^{2}$ Ellen G. White, Medical Ministry (Boise, ID: Pacific Press Publishing Association, 1963), 131. 
humankind—all the different kinds of people in a nation, the variety of levels and subcultures of society."1

Sometimes these cultures go underground. It may call for embedded disciples to identify, penetrate, and effectively disciple these subcultures in a nation, tribe, or within a clan. Each local church congregation will have to identify and target such groups in their area. For this reason, discipleship will wear different faces in every culture. ${ }^{2}$ These faces might change from time to time. Appianda Arthur, Ghanian former member of parliament, hit the nail on the head when he was quoted in an editorial of Christianity Today. He said, "In Africa, the key issues for discipleship may include bribery, corruption, and polygamy." ${ }^{\prime 3}$ This is very true of Malawi. In addition, there is need to confront evil practices and issues like domestic violence, witchcraft, fisi ${ }^{4}$ and chimwanamayi ${ }^{5}$ rituals and other unchristian practices among Christ's disciples.

${ }^{1}$ Win Arn and Charles Arn, The Master's Plan for Making Disciples (Grand Rapids, MI: Baker Books, 1998), 167. 1999, 29.

${ }^{2}$ Editorial, "Make Disciples, Not Just Converts," Christianity Today, October 25, ${ }^{3}$ Ibid.

${ }^{4}$ In Malawi fisi (hyena) is generally known as a coward animal and is associated with shady activities because it disguises itself and tends to be more active at night. Some tribes practiced unchristian rituals connected with the death of a husband. The night after burial, the deceased's relative was selected to have sex with the widow. This was arranged secretly by two elderly people of the two families. The person selected to perform this ritual was called fisi. It was their way of chasing immediate death from claiming the widow. Since rituals are hard to die, these seem to surface again.

${ }^{5}$ Chimwanamayi was a practice of sharing anything with an intimate friend. This included your wife. This favor was reciprocated on a return visit. This highly secret unchristian practice should not be assumed that it is a thing of the past. 
The contemporary Christian disciples ought to embrace Christ's incarnational ministry. Their passion will be known wherever they are. As Philip Samaan has observed, when we mix with such people, "we identify with people's needs and feelings, while pointing them to Jesus, who can satisfy their deepest longings." At times, it may mean to mix with undesirable cultures of our society.

We cannot entertain a notion that society will get better through the efforts of the government or non-government organizations (NGOs) as prescribed by others. This thinking has led Christian disciples in certain quarters of the church to initiate nonbiblical methods which unfortunately do not work. Effective discipleship of these ethnic groups demands an approach that is radical in nature. Radical approach means disciplemaking has to become the concern of every group or ministry on all levels of the church down to the local congregation. ${ }^{2}$ In general, the church has promoted special programs through its departments like Sabbath School which is not radical enough.

Christ already perfected the methods to be used in carrying out the commission. Any attempt to reform or modify, lessens the Savior's influence. ${ }^{3}$ His method is that every believer becomes an active disciple producing Christian. It entails a relationship with God and sharing of long-term relationships with those we pray for and desire to disciple.

${ }^{1}$ Philip G. Samaan, Christ's Way of Reaching People: The Fine Art of Relational Witnessing (Hagerstown, MD: Review and Herald Publishing Association, 1990), 53.

${ }^{2}$ Sine, 28.

${ }^{3}$ White, Evangelism, 525. 
We cannot make disciples until we have a life-sharing relationship with other people. Great Commission people must both be disciples in a life-sharing, learning relationship with God, and also be prepared to commit themselves to meaningful long term life-sharing relationships with others. ${ }^{1}$

The Gospel Commission connects us vertically with God and horizontally with fellow men and women. As changed people, we passionately share and disciple former acquaintances from various subcultures where the gospel found us. We know what is involved in those cultures. As Paul rightly puts it, except for God's rich mercy and His grace, we once gratified and craved for the sinful nature and followed its desires (Eph 2:3-5)

The commission creates a challenge of church planting for target groups. If it is totally unentered territory, it is best to plan ahead of time where new people will meet. A successful discipleship church planting cycle consists of "conception, development, birth, growth, maturity, and reproduction."2 Stopping short of a full cycle is a recipe for total discipleship failure. Planted churches "reproduce themselves and make disciples by planting other churches." ${ }^{33}$ Disciple making becomes a lifestyle. It signifies real maturity of the disciple. It fulfills the demands of Christ's Great Commission.

\footnotetext{
${ }^{1}$ Rose Dowsett, The Great Commission (Grand Rapids, MI: Kregel Publications, 2001), 157.
}

${ }^{2}$ Aubrey Malphurs, Planting Growing Churches for the $21^{\text {st }}$ Century (Grand Rapids, MI: Baker Books, 1998), 25.

${ }^{3}$ Ibid. 
God intended the church to be an instrument for making disciples. ${ }^{1}$ The church has "people power." 2 This is often under utilized. Disciple-making has a way of utilizing this people potential for the Gospel Commission. Research shows that concentration on laity empowerment makes a big difference between growing and dying churches. ${ }^{3}$ While other factors are just as important, if laity empowerment is left out, then the Great Commission cannot be accomplished. The need for local churches to train and incorporate the new disciples can never be over emphasized. ${ }^{4}$

Where specifically are we to begin our Great Commission assignment? What does it mean to start in Jerusalem? Ellen White answered these questions when she wrote, "The disciples were to begin their work where they were. The hardest and most unpromising field was not to be passed by. So every one of Christ's workers is to begin where he is. In our own families may be souls hungry for sympathy, starving for the bread of life. There may be children to be trained for Christ. There are heathen at our very doors. Let us do the work that is nearest. Then let our efforts be extended as far as God's hand may lead the way." 1990), 141.

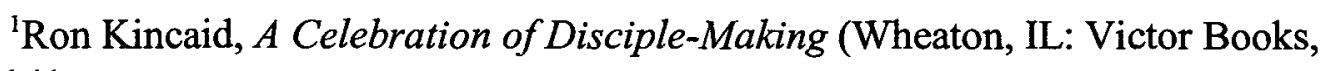

${ }^{2}$ Alvin J. Lindgren and Norman Shawchuck, Let My People Go: Empowering Laity for Ministry (Nashville, TN: Abingdon, 1990), 28.

${ }^{3}$ Christian A. Schwarz, Natural Church Development: A Guide to Eight Essential Qualities of Healthy Churches (Barcelona, Spain: M. C. E. Horeb, 1998), 22.

${ }^{4}$ George E. Knowles, How to Help Your Church Grow (Washington, DC: Review and Herald Publishing Association, 1981), 153.

${ }^{5}$ White, Desire of Ages, 822. 
In fact, discipleship starts with the opening of one's heart and repeating David's words: "Search me, O God, and know my heart; See if there is any offensive way in me, and lead me in the way everlasting" (Pss 139:23-24). A questionable lifestyle has little or no positive influence at all on those closest to the discipler. It makes it hard to work with those who really know us. Ellen White is on record saying that we fail to influence close relatives and friends because our lifestyle is not different from theirs. ${ }^{1}$ Disciples need a thorough daily conversion. They are Christ's letters and fragrance in the family, church, and community ( 2 Cor \#:2;2:16).

The Great Gospel Commission continues to be the main business of God's church. Christ has not only provided everything for the Gospel Commission, but also takes full responsibility for its success and once we obey, failure is out of the question. ${ }^{2}$ It demands from the church wise utilization of all the available resources at its disposal for discipling of all nations. Our time, efforts, and strength are not enough. The change and action must begin with us. Discipleship is a personal; relationship and experience with Jesus Christ.

\section{Summary}

Discipleship strategy is affirmed biblically and theologically. Systematic discipleship helps the church in both quality and numerical growth. It has a ministry of parenting new disciples to maturity. "The Christian task of today is no less than the bringing of the spirit of Christ into every part and every relationship of life throughout the

${ }^{1}$ Ellen G. White, Fundamentals of Christian Education (Nashville, TN: Southern Publishing Association, 1923), 289.

${ }^{2}$ White, The Desire of Ages, 822. 
world." This work will not be finished by human wisdom. God's word to Zerubbabel sums it all: "Not by might nor by power, but by my Spirit, says the Lord Almighty" (Zech $4: 6)$.

${ }^{1}$ Edwin E. White, The Story of Missions (New York, NY: Friendship Press, 1926), 210-211. 


\section{CHAPTER 3}

\section{ANTHROPOLOGICAL AND MISSIOLOGICAL}

\section{REFLECTIONS}

\section{Introduction}

The sense of belonging is a powerful motivation which binds a society closely together. Individuals go through demanding rituals in order to be identified with their people. Every generation feels an obligation to pass on its core values to the next generation of young people. In this way, Malawians were able to preserve their traditional practices including religion, oral history, and ritualistic ceremonies.

The Christian missionaries brought the light of the gospel to the indigenous Malawians who were already religious in their own ways. Christianity helped Malawians to know the love and the power of the God they revered and worshiped. Christ's gospel of love brought an end to tribal wars and slave trade. With the dawn of Christianity, Malawi became a largely Protestant country.

\section{Malawi}

Malawi, known as "the warm heart of Africa," is a landlocked country in the central part of the sub-Saharan Africa. It has a population of about twelve million 
people. ${ }^{1}$ It is bordered by Tanzania in the north and northeast, Mocambique in the east, south and south west, and Zambia in the west. ${ }^{2}$

Malawi was formerly known as Nyasaland but changed its name when it became independent from Britain in 1964. The name "Malawi" is derived from Maravi, name of one Bantu group of people who were along Lake Malawi. Etymologically, Maravi means "Flames of Fire." Archeological findings of the earliest human remains and tools from the Stone Age sites, indicate that the inhabitants were "hunters and food-gatherers." ${ }^{, 4}$ At the same time, the people had religious shrines like M'Bona in Nsanje District. ${ }^{5}$

The country is divided into three geographical regions composed of the north, central, and the south which is densely populated. The north has the smallest population and was known in the past as "dead north." There is no one single ethnic group of people more dominant than others. Malawi has so far been a peaceful country.

\section{The Christian Pioneer Missionaries}

When the Western Christian missionaries came to Africa with the gospel, they felt

1"Malawi." January 10, 2006, http://cia/publications/factbook/geos/mi.html (January 24, 2006).

${ }^{2}$ Malawi Yearbook (Blantyre, Malawi: Blantyre Print and Packaging, 1978), 7.

${ }^{3}$ Cynthia A. Crosby, Historical Dictionary of Malawi (Metuchen, NJ: The Scarecrow Press, Inc., 1980), 75.

${ }^{4}$ Bridgal Pachai, Malawi: The History of the Nation (London, Great Britain: Longman, 1973), 1.

${ }^{5}$ Bengt Sundkler and Christopher Steed, $A$ History of the Church in Africa (Cambridge, UK: Cambridge University Press, 2000), 469.

${ }^{6}$ Christian P. Potholm and Richard Dale, eds., Southern Africa in Perspective: Essays in Regional Politics (New York, NY: Free Press, 1972), 207. 
that African traditional religions could not co-exist with Christianity. The missionaries did not see anything compatible with the gospel. They condemned African "drums, dances, traditional rituals, sacrifices to spirits and divination rites . . . because they were directly or indirectly related to traditional religions." Culture and the whole African belief system was judged evil. African rituals were seen as pure magic and devil worship. Africa was labeled a dark and heathen continent plagued in slave trade.

"Take 'Christianity, civilisation and commerce' into the interior of Africa, ... and the slave trade will be destroyed at its source." ${ }^{2}$ This appeal by David Livingstone stirred the mission-minded British people into action. Lake Malawi was seen as a key passage to the interior of Central Africa in the sub-Saharan region. The European missionaries entered Malawi during the second half of the nineteenth century. By the beginning of the twentieth century, the country was described as "a Protestant Protectorate."”

The pioneers of missions faced proponents of slave trade, unfriendly warring tribes, harsh tropical climate, malaria, and premature tragic deaths among their numbers. ${ }^{4}$ The hardships could not dampen the spirit of missions in those early pioneers. They had already counted the cost and made unwavering commitment. They were ready to pay the price. Pioneers like Rev. William Percival Johnston and Chauncy Maples "selected their

${ }^{1}$ Paul G. Hiebert, R. Daniel, and Tite Tienou, Understanding Folk Religion: $A$ Christian Response to Popular Beliefs and Practices (Grand Rapids, MI: Baker Books, 1999), 20.

${ }^{2}$ Oliver Ransford, Livingstone's Lake: The Drama of Nyasa Africa's Inland Sea (New York, NY: Thomas Y. Crowell Company, 1967), 73.

${ }^{3}$ Linden, 43.

${ }^{4}$ Kenneth S. Latourette, Missions Tomorrow (New York, NY: Harper \& Brothers Publishers, 1936), 72. 
tombstone epitaphs before they left England and by 1900, of the 200 missionaries, 57 had already died in service."' Although they knew the dangers, they could not do otherwise because as James Stewart said, "The highest quality in missionary motive is love and loyalty to Jesus Christ."2 Their undaunted spirit gave Malawi the legacy of Christian orientation. Malawians still hold David Livingstone in high esteem. John Thiessen found that people mention Livingstone's name "with reverence, for it was he who made possible all the wonders that the people enjoy."”

People might remember Livingstone as an explorer, but he saw himself first and foremost as a pioneer missionary rather than an explorer. ${ }^{4}$ The London Missionary Society (LMS) sponsored his first African mission trip during which he concluded that slave trade was "an affront to God." In 1857 while back home, he made a passionate appeal for evangelization of Africa. Unlike others, he saw in the uncivilized people of Africa an image of God. Upon return to his homeland, Livingstone made his famous speech at the University of Cambridge which led to the formation of the Universities' Mission to Central Africa (UMCA) composed of Oxford, Dublin, and Durham

${ }^{1}$ Ransford, 146.

${ }^{2}$ James Stewart, Dawn in the Dark Continent; or Africa and Its Missions: The Duff Missionary Lectures for 1902 (Edinburgh, Great Britain: Oliphant Anderson \& Ferrier, 1903), 342-343.

${ }^{3}$ John Caldwell Thiessen, $A$ Survey of World Missions, rev. ed. (Chicago, IL: Moody Press, 1961), 279.

${ }^{4}$ George Herbert Wilson, The History of Universities' Mission to Central Africa (Freeport, NY: Books for Libraries Press, 1936), 1.

${ }^{5}$ Ransford, 91. 
universities. ${ }^{1}$ This was a historic moment and was going to change the future of Africa.

In 1861, Bishop Mackenzie led the first UMCA missionaries to Malawi and set up their mission station at Magomero, in Chiradzulu, southern region. ${ }^{2}$ They knew that the ability to communicate the gospel in the language of the people was a key to their effectiveness. They learned the language and in 1862 translated the "Lord's Prayer and other Scripture passages into Mang'anja." ${ }^{\text {Th }}$ The progress was soon to be disrupted. There were a number of adverse factors which worked against the missionaries. They left the station due to slave-trade activities, climate, and tropical diseases which claimed several lives including Mackenzie himself. ${ }^{4}$

It was not until 1875 that Robert Laws led another party, the United Free Church of Scotland (UFCS), who initially started at Cape Maclear on the shores of Lake Malawi in Mangochi. They crossed the lake and set up another mission station in the northern region at Bandawe, Nkhatabay, somewhere between 1878 and 1879..$^{5}$ In 1894, they went further into the inland and established Livingstonia Mission on a geographically higher level in memory and honor of David Livingstone. ${ }^{6}$ The Anglican and Presbyterian churches were the first to be established by pioneer missions from England and Scotland. 1945), 240.

${ }^{1} \mathrm{John}$ Aberly, An Outline of Missions (Philadelphia, PA: Muhlenberg Press,

${ }^{2}$ Pachai, 85.

${ }^{3}$ Bridgal Pachai, ed., The Early History of Malawi (Evanston, IL: Northwestern University Press, 1972), 347.

${ }^{4}$ Ibid., 346-347.

${ }^{5}$ James Johnston, Robert Laws of Livingstonia (London, Great Britain: Pickering \& Inglis, n.d.), 44.

${ }^{6}$ Ibid., 92. 
In the south, the Established Church of Scotland (ECS) started Blantyre Mission in 1876 in memory of Livingstone's birth place in Scotland. ${ }^{1}$ Today, it continues to be the head office of the Church of Central Africa Presbyterian (CCAP) synod which has jurisdiction over the whole southern region. The missionaries embarked on a holistic education of the heart, the mind, the hands, and the body. The pioneers worked along the four broad lines, namely, "religious, medical, educational, and industrial."2 Missions in Malawi adopted this pattern which as much as possible was later emulated by those who followed, among them the Catholics, Seventh-day Adventists, Dutch Reformed, Zambezi Industrial and others. Churches have continued to offer these social services along with the government.

The ensuing years witnessed an increase in the number of missions, churches, schools, students, artisans, and well-qualified indigenous workers in various fields. The highest point was the Chinyanja New Testament which came out in $1886 .^{3}$ This was a historic milestone in the history of Malawi missions. It was a beginning of many good things. As early as 1906 , the country saw the birth of an African initiated church which had well over 10,000 followers by $1908 .^{4}$ Today, many such churches have increased. One of them has added missionary activities in the region, Europe, and America. ${ }^{5}$

\footnotetext{
${ }^{1}$ Ransford, 140.

${ }^{2}$ Johnston, 48.

${ }^{3}$ Ibid., 103.
}

${ }^{4}$ Pachai, Malawi: The History of the Nation, 135.

5“"The Living Waters" founded by Apostle Stanley Ndovi is an independent indigenous church which is a branch of the Pentecostal Movement. It has spread to South Africa, Europe, and South Bend, Indiana, in the United States. 
The Content of the Message

The burden of the missionaries was Christ's great Gospel Commission to "go and make disciples of all nations, baptizing them in the name of the Father and the Son and of the Holy Spirit, and teaching them to obey everything I have commanded you" (Matt 28:19-20). According to Stewart, one of the earliest missionaries at Livingstonia, the one aim of the missionaries was "to give the knowledge of God and Christ as the one Saviour of mankind." Although the missionaries may differ in many ways, they all carry the burden of the gospel as they understand it.

They had a message of God's love with a call for repentance and reformation. The churches taught biblical monogamous marriage. The Christian churches did not condone polygamy. The Montfort nuns excluded second wives in their preparatory classes for baptism. ${ }^{2}$ In general, they were very strict. In 1904, of the 900 candidates who had applied for baptism at Bandawe, only 151 were baptized. ${ }^{3}$ While preaching was the primary means of evangelism, they also taught reading and writing skills and further assisted the people to develop legitimate trade. ${ }^{4}$ The Australian Baptists who began the Nyasa Industrial Mission in 1892, trained their "converts in crafts and simple agriculture methods." ${ }^{\circ}$ This was a follow-up after evangelizing them.

It was also a message of peace for it united the warring tribes. Further, it greatly

${ }^{1}$ Stewart, 212.

${ }^{2}$ Linden, 240.

${ }^{3}$ McCracken, 189.

${ }^{4}$ White, The Story of Missions, 179.

${ }^{5}$ Thiessen, 280. 
crippled and brought a death knell to the rampant slave trade which at that time saw about 20,000 slaves passing through Lake Malawi yearly to markets on the eastern coast of Africa. ${ }^{1}$ The content of the message was in its power to transform and restore the lost image of mankind. The indigenous people accepted the message and some became missionaries within Malawi and in neighboring countries in the region.

However, in spite of the good motives and success, the pioneer missionaries did not engage African traditional religion (ATR) in critical contextualization. It seemed to be normal then. This omission is a question of discussion for the contemporary missions. Reflection on Malawian Christianity shows the need for a contextualized discipleship which draws and borrows positive aspects from ATR to develop true Christian disciples.

\section{Seventh-day Adventist Beginnings}

It may be proper to say that the SDA Church entered Malawi in two stages. First, it was George James, a young graduate of English descent from Battle Creek College who went to Malawi, Africa as a self-sponsored missionary. From his own correspondence dated March 19, 1893, which appeared in the official church paper of August 1 of the same year he arrived in Malawi in $1893 .^{2}$ Going by this account, he became the first Seventh-day Adventist Church pioneer missionary of the work in Malawi. His first missionary contact was Rev. David C. Scott, in-charge of the Established Church of

${ }^{1}$ Johnston, 52.

${ }^{2}$ George James, "In the African Interior," The Advent Review and Sabbath Herald, August 8, 1893, 502. 
Scotland (ECS) at Blantyre Mission. ${ }^{1}$ Due to lack of accommodation, James moved to live with Joseph Booth, the founder of the Zambezi Industrial Mission who had several farms and the nearest was at Mitsidi in Blantyre. ${ }^{2}$

Booth had briefly heard about the Sabbath truth from the SDA missionaries in Cape Town. This background paved the way for more Bible studies on the subject between the two missionaries. As a result, Booth allowed his farm employees to observe both the seventh-day Sabbath and Sunday. ${ }^{3}$

Like the early disciples, some of the farm employees went into the surrounding villages every Sunday to share the little knowledge of the precious truth they had learned the previous day. ${ }^{4}$ They felt the same obligation Paul had to share the discovered truth with others who had not known it (Rom 1:14-15).

James left Malawi to visit and share his exciting experiences with the church-sent missionaries at Solusi, Zimbabwe. Unfortunately, he was "stricken with malaria" which claimed his life on the way and was quickly buried in an unknown grave. James had aroused interest in some indigenous Malawians but had not yet established his mission station. Nevertheless, his efforts were not in vain. The seed sown in Booth was yet to germinate. After several years of heart-searching, Booth became an advocate of that truth.

${ }^{1}$ George James, "In The African Interior," The Advent Review and Sabbath Herald, August 1, 1893, 485.

${ }^{2}$ George James, The Advent Review and Sabbath Herald, August 8, 1893, 502. ${ }^{3}$ Tbid.

${ }^{4}$ George James, The Advent Review and Sabbath Herald, August 15, 1893, 518. 


\section{Joseph Booth and Adventist Work in Malawi}

The name of Joseph Booth is connected with the establishment of several church organizations in Malawi but rarely with the Adventist work. Surprisingly, it is clear from the church correspondences that he was a key player in pioneering the Adventist work. He appeared briefly at a critical moment and with his influence, the church took a bold action to officially enter Malawi. Although his official position is not known, yet he appears to have been the chief correspondent with the General Conference (GC). Booth was also instrumental in the recruitment of some of his former employees like Morrison Malinki. ${ }^{1}$ Booth is really a link between the self-sponsored and the church-sponsored pioneer missionaries. He himself was part of the missionary team that officially started the work in Malawi.

Booth had already founded other missions aimed at uplifting the indigenous people not only spiritually but also economically and politically. The guiding principle in these mission stations was empowerment of the local people so that they would be incharge of their country's affairs. ${ }^{2}$ His first encounter with the Sabbath truth and now with James left him wrestling with the subject. ${ }^{3}$ The time came when he could no longer ignore the Sabbath. He had to do something about this new light.

One time while Booth was teaching the ten commandments to a group of local

${ }^{1}$ Gary Land, Historical Dictionary of Seventh-day Adventists (Lanham, MD: Scarecrow Press, 2005), 185.

${ }^{2}$ Pachai, Malawi: The History of the Nation, 132-133.

${ }^{3}$ Joseph Booth, "The Call for the Message in Central Africa," The Advent Review and Sabbath Herald, May 13, 1902, 13. 
people on Sunday, one of them asked him what day of the week the fourth commandment referred to. He answered that the previous day was the seventh-day Sabbath referred to in the fourth commandment. The questioner asked whether the white men had more power than God to change it from Saturday to Sunday? ${ }^{1}$ According to Booth's own account in his report given in Battle Creek on Sabbath, April 26, 1902, that Chief Chatyika [Chatayika] who had raised the question and fourteen others had already started observing the seventh-day Sabbath in $1893 .^{2}$ This group of Malawians saw the truth and were bold to accept it. It did not matter to them what others would think about their decision.

This above experience regarding Sabbath truth reminded Booth the warning George James had sounded to him that he would not rest until he had settled it. Booth had come to America with a "resolve to look into this matter."3 His search led him to Plainfield, New Jersey where he came into contact with the Seventh-day Baptists whose teachings he accepted, having found them much easier. ${ }^{4} \mathrm{He}$ also got financial help for opening a Sabbath-keeping mission station back in Africa from a private association of the Plainfield friends. While in their service, at the Plainfield coffee plantation in Thyolo, he soon came to realize that he had not fully addressed the Sabbath question. Booth continued to search for the Sabbath truth which he had heard in Cape Town, from George James, and now which the "heathen" African chief had accepted.

On his next travel to the United States, he determined to look for the Seventh-day

${ }^{1}$ Ibid.

${ }^{2}$ Tbid., 14.

${ }^{3}$ Ibid.

${ }^{4}$ Ibid. 
Adventist believers. While in New York, he met with Betty Hurd Haskell and in Chicago he met Elder Hankins, the people he had briefly met in Cape Town. ${ }^{1}$ His personal story and his past experiences in Africa as well as the continuing needs of Malawi generated lots of interest among the Adventist believers at the Lake Union Conference in Chicago. In no time arrangements were made for him to speak at the church headquarters in Battle Creek. He related his story and told the authorities about the Plainfield property that was on sale.

The church started negotiations with the Plainfield private association. An offer was made to the SDA representatives involved in the discussions. The association members agreed to transfer the property for four thousand dollars although it was now worth nearly twenty-five thousand dollars. ${ }^{2}$ The continuation of the Sabbath teachings they had introduced was their one chief concern. Preference was given to the SDA Church because they were going to continue preaching the Sabbath truth. Since Booth himself was now with the SDA Church, they felt satisfied to transfer the property to them.

The Lake Union Conference was the first to vote $\$ 500$ from its surplus funds, California gave $\$ 2,000$ and other conferences joined in giving a total of $\$ 7,000$ for the work in Nyasaland. All this activity was taking place with Booth as a catalyst. The Battle Creek Church voted to pay Booth's salary for one year. ${ }^{4}$ Within the first six months, the mission board had enough funds to make the first payment of $\$ 2,000$ towards

${ }^{1}$ Ibid.

${ }^{2}$ W. A. Spicer, "The New Missionary Enterprise," The Advent Review and Sabbath Herald, May 27, 1902, 17.

${ }^{3}$ Ibid.

${ }^{4}$ Ibid. 
the property and a balance to start the work. ${ }^{1}$ Booth and his family were soon on their way back to Malawi with a stop for a conference in London.

In response to a request from Malawi for a black missionary, Thomas H. Branch from Colorado was appointed by the church. ${ }^{2}$ The people thought they would easily have access to a black person. He with his nurse-wife, daughter-teacher, and two young boys left in June to join the Booth family in London on their way to pioneer the work in Livingstone's land. The Colorado Conference pledged to support him and his family. ${ }^{3}$

The British consul at Chinde, Mozambique detained the Branch family for no apparent reason. Booth pleaded for their release for three days but the consul gave him a deaf ear. The family was released after nine days and was able to reunite with the Booth family on August 29, 1902. ${ }^{4}$ This sad experience had no effect on their commitment.

Booth had been a spiritual father to a number of Malawian employees on his farms. Morrison Malinki, a teacher by profession, was one of his farm workers when Booth was in the service of the Zambezi Industrial Mission. ${ }^{5}$ He had baptized Morrison and his wife Mabel in 1892 after sharing the Sabbath truth with the couple as it was taught by the Seventh-day Baptists. ${ }^{6}$ Having known the couple, Booth later shared with them additional light on the Sabbath as he himself had understood and accepted from the

${ }^{1}$ Ibid.

${ }^{2}$ Ibid., 17-18.

${ }^{3}$ Ibid., 18.

${ }^{4}$ Mrs. Thomas Branch, "British Central Africa," The Advent Review and Sabbath Herald, November 18, 1902, 17.

${ }^{5}$ Seventh-day Adventist Encyclopedia, 1996 ed., s.v. "Malawi."

${ }^{6}$ Land, 185. 
Seventh-day Adventists. ${ }^{1}$ This fatherly spirit continued.

It was Booth who introduced Branch to several of his African friends including Malinki who had his own self-supporting schools around Monekera in Chileka area, Blantyre. Branch recruited this African educator for the new mission. Malinki and Mabel Branch taught together in the newly opened school at Plainfield. Later, Malinki was re-baptized and became one of the first African workers to give strong leadership to the work in Malawi. Joel Rogers who took over from Branch persuaded Malinki to hand over his self-supporting schools to the church in $1908 .^{2}$

Booth accomplished much behind the scenes starting with his hospitality offered to James. He was a bridge between the Baptist Plainfield proprietors and the Adventist Church. He teamed up with the Branch family as the first pioneer missionaries of the church work in Malawi. His former employees followed him because of his influence. He even reported and expressed his gladness to see the black American couple increase in influence. ${ }^{3}$ These kinds of people are rare. Booth deserves a prominent place in the annals of the Seventh-day Adventist Church work in Malawi.

\section{Growth of the SDA Work}

The growth was very slow. It called for much patience and prayer. The people were settled in traditional beliefs. Others had already accepted Christian teachings from the well-established Scottish missionaries and others. Malawians marveled at the

${ }^{1}$ Ibid.

${ }^{2}$ Seventh-day Adventist Encyclopedia, 1996 ed., s.v. "Malinki, K. Morrison."

${ }^{3}$ Joseph Booth, "British Central Africa," The Advent Review and Sabbath Herald, December 23, 1902, 17. 
teachings and often wondered why it took Adventists so long to arrive. ${ }^{1}$ Branch went about holding evangelistic meetings in the surrounding villages while at the same time familiarizing himself with the station.

Schools for Mission Advancement

Soon after arrival, Mabel Thomas opened an elementary school. By November 1902, Mrs. Branch reported a flourishing school of about forty eager students, the majority of whom were young men with several women and children. ${ }^{2}$ The year 1905 saw the opening of the first out-school at Masenjere, six miles away in a schoolhouse built by the local people with Johan Mbendela as a student-teacher. ${ }^{3}$ It was in the same year that the first historic baptism of Morrison Malinki and six other Malawians took place at the Plainfield Mission. ${ }^{4}$

In 1907, Rogers changed the name of the mission station from Plainfield to "Malamulo" which means commandments. ${ }^{5}$ Evangelism was effectively done through the schools. More schools were opened in the surrounding area. In 1908, Samuel M. Konigmacher and Peter Nyambo opened Matandani in Neno-Mwanza. ${ }^{6}$ Four years later, A. T. Robinson introduced teachers institutes, Young Peoples Society, plus Dorcas

${ }^{1}$ Mrs. T. H. Branch, "In the Land of Livingstone," The Advent Review and Sabbath Herald, August 3, 1905, 17.

${ }^{2}$ Mrs. Branch, 17.

${ }^{3}$ Thomas H. Branch, "A Word From Nyassaland," The Advent Review and Sabbath Herald, April 27, 1905, 13.

${ }^{4}$ SDA Encyclopedia, "Malawi."

${ }^{5}$ Ibid.

${ }^{6}$ Matemba, 35 . 
activities for women and girls. ${ }^{1}$ It was a new day for the young church in Malawi.

\section{Medical Evangelism}

Nurse Irene Fourie started the medical work in 1915 from a farm building at Malamulo. ${ }^{2}$ The medical work survived various interruptions. It received a boost when Dr. Carl Birkenstock arrived to be the first medical director and two years later, a permanent building was completed housing two wards of 15-beds. ${ }^{3}$ Today, by Malawian standards the medical work is advanced with hospitals at Malamulo and Blantyre. There are training programs for nurses, clinical officers, and laboratory technicians at Malamulo Hospital who are highly sought by other health delivery services. The church operates clinics scattered throughout the country under the auspices of the Adventist Health Services. There are dental practices in Blantyre and Lilongwe. A new development is that a good number of graduates from Malamulo Hospital operate their own dispensaries where they witness for their Master.

\section{General Development}

Malamulo was the headquarters for the work in Malawi until its move to Blantyre about 1919. In 1925, they were granted a union status with supervision responsibility over some parts of Mozambique and Zambia. ${ }^{4}$ The organization of the union witnessed a rapid growth and expansion of the work with its base on the purchased property.

\footnotetext{
'SDA Encyclopedia, "Malawi."

${ }^{2} S D A$ Encyclopedia, "Malamulo Hospital."

${ }^{3}$ Ibid.

${ }^{4}$ Ibid.
} 
In 1926, a small handpress was set to work at Malamulo Mission station for printing church materials. It also grew and handled a number of vernacular languages from various re-aligned division territory.

In 1928, R. G. Pearson and James Ngaiyaye opened Luwazi Mission School in Nkhatabay District. Many of the students and church members were from the failed Seventh-day Baptist Mission dating back to 1911. The following year James Malinki opened Lunjika (Mombera) Mission in Mzimba District. Kamanja (Zomba ) and Lakeview Missions opened in 1934. Malawi was overwhelmed by the missionary spirit, the "spirit which desires to be sent." This is the spirit of the gospel. A person accepts Christ's teachings and feels an obligation to share with others who have not heard. One who has the missionary spirit is listening for the call, "Whom shall I send and who will go for us?"'

The work that started in faith has grown beyond recognition in many ways. Many dedicated Malawian nationals have given uninterrupted faithful service in the pastoral, educational, publishing, and medical lines of the work. With the exception of the medical institutions, almost all the leadership positions are nationalized.

Ministerial training has been offered at various times from Malamulo, Lunjika, and lately at Lakeview Seminary which opened its doors in 1980 . The majority of the current serving pastors are Lakeview Seminary graduates. The school which has been updated to a college, has started offering additional disciplines in education and business studies. These other disciplines will help to strengthen the work.

${ }^{1}$ W. A. Spicer, "The Missionary Spirit," The Advent Review and Sabbath Herald, May 27, 1902, 3. 
Lakeview has also been used as a lay training center aimed at improving the ministry of the lay persons who continue to take care of the churches in the absence of the pastors who have large districts under their supervision. The institution holds a key to the success of Malawi's discipleship strategy. The people come here from all the three field territories of Malawi. The pastors and lay persons trained at Lakeview are the potential leaders in disciple-making in the local churches.

\section{Malawian Culture and Christian Discipleship}

The rites of passage mark critical stages of one's life cycle. These rites of passage move an individual a step higher in status. Some rites involve name change. Like most parts of Africa, Malawi has some rites of passage considered critical. The rituals include isolation and intensive instructions given by respected and experienced gurus (anankungwi). A climax on the day of release from the camp is characterized by traditional dances and festivals. The initiated persons become full members of their society. They are integrated in all tribal and communal activities.

For an African, culture was a religion with a code of conduct. The standards were adhered to in respect of the deceased ancestors. They believed that one misbehaved person could invoke the spirits of the dead and put the whole community in trouble. They feared that the angered spirits (mizimu) would withdraw their favors from them. To avoid this, they had to defend cultural practices as sacred dogma. ${ }^{1}$ To a certain degree, it was a religion of fear (mantha). It can almost be said that they glorified fear. One Malawian proverb says, Khwangwala wa mantha anafa ndi ukalamba meaning, "A cowardly crow

${ }^{1}$ John V. Taylor, The Primal Vision: Christian Presence Amid African Religion (London, Great Britain: SCM Press Ltd., 1963), 57. 
died of old age." As it can be seen, fear was associated with long life.

Such a past with deeply held traditional practices is bound to have residuals which may not be known. These are often hidden to the eyes and ears of a foreigner. It is even worse when there is a language barrier. Since fear (mantha) was a major factor in traditional religion, there is a danger of its continuity even today. The contemporary disciple-makers might also be guilty of using mantha to induce responses instead of love (chikondi). Unfortunately, decisions made out of fear seem to be short-lived. God's appeals are based on love, not fear (Rom 2:4).

Generally Malawians are quiet and, as much as possible, avoid arguments. Some people have considered them humane, gentle, hospitable, and friendly. ${ }^{1}$ Others have perceived them as easy-going people who prefer to say, "yes, sir" (inde, bwana) to everything without meaning it. They seem to find it easy to say they will do whatever it is without any commitment. Their seriousness to back words is questionable. One missionary described the Mang'anja tribe as people who make "promises which they never intend to keep."2 Malawians seem to equate voicing difference of opinion with impoliteness. This culture of silence could easily be a threat to Christianity. Adding to the problem, when Christianity was planted, the missionaries judged the culture of the host as inferior to theirs. An African was not taken as an equal partner. Penetrating such a culture calls for respect, patient probing, and a sincere dialogue where both parties are equal. An environment of respect creates trust between the parties.

'Joseph Booth, "The Call for the Message in Central Africa," The Advent Review and Sabbath Herald, May 13, 1902,12.

${ }^{2}$ Mabel Branch, "Our Nyassaland School" The Advent Review and Sabbath Herald, April 6, 1905, 13. 
Michael Gelfand says a person can continue to cherish beliefs of "his own religion without necessarily practising it, and at the same time be a practising Christian."1 Hiebert, Shaw, and Tienou confirm this disturbing reality. "Missionaries brought formal Christianity encoded in systematic theology, churches, and institutions such as schools and hospitals. They assumed that traditional religions would die out as the gospel displaced animistic beliefs and practices. Today it is clear that old ways do not die out, but remain largely hidden from public view."2

This state of Christianity does not serve discipleship well. The missionaries preached the gospel of repentance which to an African cultural lenses of the time, the call was for obvious external practices like polygamy, beer drinking, and anything associated with public spirit worship. These activities were associated with heathenism (chikunja). Once a person put such things aside, they were allowed baptism and membership. The indigenous leaders who knew that during crisis some Christians reverted to unchristian practices, emphasized in their instruction the importance of doing. It was common to hear prayers like this, "Lord, help us so that the words we have heard, will not be just like a passing wind but that we should be the doers of the word." Ambuye mutithandize kuti mau amene tamva asakhale ongopitirira ngati mphepo, koma kuti tikhale ochita. Any teachings that disturbed them in their endearing rituals were dubbed as belonging to European domain (za azungu). Such teachings were left at the church door. The people secretly continued in their old ways. Nobody dared to report these well kept secrets. 1959), 2.

${ }^{1}$ Michael Gelfund, Shona Ritual (Cape Town, South Africa: Juta \& Co., Limited, ${ }^{2}$ Hiebert, Shaw, and Tienou, 13. 
Superstition went hand in hand with Christianity. Salt, mchere, was one commodity connected with superstition. It was like the leaven mentioned in the Bible (Exod 12:15; Matt 16:6). The salt myth was that if touched by an unclean or unfaithful spouse, it would cause illness or death especially if they had small children under five. The child would die of tsempho, meaning an illness resulting from disregard of culture or breaking a moral taboo.' Pregnant or women who had recently delivered or any female going through monthly periods, were considered unclean. They had to avoid salt like poison. They ate salted food but they themselves were not to put the salt in food. Now, when one reflects on the past, deaths attributed to tsempho seem to have been cases of obvious malnutrition.

The Christian pioneer missionaries carried the gospel to penetrate such an intricate culture clothed in rich symbolism and mystic practices. The missionaries had a duty to teach the African tribes according to the gospel commission. However, hard as it may have been to understand fully about the practices, yet it was equally important to differentiate between innocent cultural practices and those that clearly violate Scriptures. This is no sanction for contextualization of the message to simply accommodate unchristian practices. "The Christian's life is not a modification or improvement of the old, but a transformation of nature." When one accepts the Lordship of Jesus Christ, it means putting aside anything contrary to His teachings because certain "customs of the people are worthless" (Jer 10:3). They militate against the gospel.

${ }^{1}$ What was known as tsempho, breaking of a moral taboo, seems to have been cases that had clear symptoms of malnutrition. However, it was used to scare people from being promiscuous. Unfortunately, this scare tactic did not work.

${ }^{2}$ White, Desire of Ages, 172. 
Anthropological and missiological reflections are healthy for a church that seeks to make disciples and not just converts. Today, as Christopher Dawson says, the threat to Christianity is not traditional culture, but "the secularized culture of the present which is being tried and found wanting."1 In spite of past attempts to demolish old ways, one still finds unchristian practices that hinder effective disciple-making.

Jealousy, corruption, superstition, witchcraft, gender segregation, the prevalence of HIV/AIDS among Christians, and other practices cannot just be swept under the cultural mat. These issues might be indicators of some deep-rooted spiritual problems facing the church in Malawi and the whole of modern Africa. The issues present a challenge necessitating contextualized disciple-making that addresses past distortions.

\section{Traditional Religion}

Malawians are in general a religious people. The Oxford English dictionary defines religion as "belief in or sensing of some superhuman controlling power or powers, ... a system defining a code of living."2 The African traditional religions (ATR) were cultural-based with no written set of beliefs. It has been preserved through verbal communication from one generation to another. ATR falls under primal religion, as it also had no missionary activities, but simply a way of life passed orally from generation

${ }^{1}$ Christopher Dawson, The Historic Reality of Christian Culture: $A$ Way to the Renewal of Human Life (London, Great Britain: Routledge and Kegan Paul Ltd., 1961), 22.

${ }^{2}$ New Shorter Oxford English Dictionary (1993), "Religion. 
to generation. ${ }^{1}$ Offering sacrifices marked their high points of worship in times of plagues, drought, or to express gratitude for good harvest.

Traditionally, the early Africans lived in a spirit world. It is no big surprise that anthropologists classify the ATR as "animistic." This label carries the notion of attribution of spirit to plants, stones, and other inanimate objects. Africans revered the spirits and sometimes made the dead appear more powerful than the living. ${ }^{2}$ Books by anthropologists are said to insist that the primal tradition was ancestral worship. ${ }^{3}$

Yet, Africans have always been a religious people. Their way of worship was expressive of their joy or sorrow through songs and dances to a sound of drums. In fact, the drum was used to communicate messages. By its size and sound, they were able to know whether there was death, beer, a wandering fierce beast in the area, or a church meeting. The place of the ancestors and spirits in religion calls for further investigation.

As one Malawian puts it, the dead were taken as "part of the community because they represent a past which constitutes the present." Death brings changes among the living. It forces people to find an alternative new beginning without the departed loved ones. For an African, the present and the future were always connected to the past which was the source of one's "identity and self-realization."

${ }^{1} \mathrm{~S}$. A. Thorpe, African Traditions: An Introduction (Pretoria, South Africa: University of South Africa, 1991), 1-2.

${ }^{2}$ Lotourette, 72 .

${ }^{3}$ Ransford, 28.

${ }^{4}$ Harvey J. Sindima, Drums of Redemption: An Introduction to African Christianity (Westport, CT: Greenwood Press, 1994), 124.

${ }^{5} \mathrm{Ibid}$. 
Africans find it hard to accept that they originally worshiped the spirits of their dead ancestors. This problem might be a result of failure to explain clearly the relationship between their belief system and the spirits. In this regard, Stephen Kauta Msiska thinks ancestor spirit worship is inconceivable even to "the most ignorant people of Malawi." He argues that if this had been the case, then "Christianity would have no meaning at all to a people for whom there was no preparation for or revelation of God."2 The African belief system was in one true God of Israel. In other words, the spirits were never worshiped or approached in isolation of God. They were believed to be a traditional means to reach God. Everything connected with worship was done with great care and respect. There was a sense of awe and wonder. It went beyond human worship.

Msiska further informs his readers that traditionally, Malawians had already embraced monotheistic faith before the advent of Christianity. ${ }^{3}$ Their belief system had multiple spirits but one Supreme Being. God was the object of their worship; not the spirits of dead human beings. He cites Tumbuka tribe in the north of Malawi that had supernatural names for God, way before the missionary era. They addressed the dimly known Being as "Kamanyi-manyi-the All-knowing One; Kajilengi-the self-created one; Mziribanda-the one without bounds, the all-embracing one; Chiuta-the great bow of heaven; Chilera Balanda-the nourisher of orphans; and many more."^4 These names are always singular and never plural in a culture that uses the plural form a lot for respect.

\footnotetext{
'Stephen Kauta Msiska, Golden Buttons: Christianity and Traditional Religion Among the Tumbuka (Blantyre, Malawi: CLAIM, 1997), 24.

${ }^{2}$ Ibid.

${ }^{3}$ Ibid., 25.

${ }^{4}$ Ibid., 12.
} 
This means that Christianity in Malawi or Africa did not start in a vacuum. The spirits were engaged as mediums to the transcendency. From the Shona tribe of Zimbabwe, Gelfand says, "The reader will learn that there are a number of powerful spirits believed capable of producing rain, ensuring good crops and the essential blessings to the land-all under the omnipotent Supreme Being (Musikavanhu or Mwari). ${ }^{1}$

This was the belief in the whole sub-Saharan Africa. Jomo Kenyatta of Kenya echoed the same sentiments. "The Gikuyu believes in one God, Ngai, the creator and giver of all things.... He has no father, mother, or companion of any kind. His work is done in solitude." ${ }^{2}$ These concepts were passed on orally from one generation to another. They did not have any written works. Yet, their view of God could not be attributed to any living or dead person.

Continuing the debate, Msiska points out that indigenous Malawians of Bantu origin had knowledge of a higher Being prior to arrival of the western missionaries. ${ }^{3}$ Joseph Booth said the same about the Mang'anja tribe of Malawi. "They all believe in Mutunga ["God" correctly spelled "Mulungu"], the great Supreme Being."4 Elmslie, another non-African writer, noted that close examination reveals that the people had "existence of their belief in a Providence, a Judge, and an Almighty King." James

${ }^{1}$ Gelfand, 2.

${ }^{2}$ Jomo Kenyatta, Facing Mt. Kenya: The Tribal Life of the Gikuyu (New York, NY: Vintage Books, 1962), 224.

${ }^{3}$ Msiska, 22-23.

${ }^{4}$ Booth, 13 .

${ }^{5}$ W. A. Elmslie, Among the Wild Ngoni (London, Great Britain: Frank Cass \& Co. Ltd., 1970), 35. 
Johnston caps it all when he says, "No doubt that the natives believe in a supreme being built up out of ancestral worship." Africans were cognizant of the fact that this Supreme Being could not dwell together with people because He was not one of their equals.

As a sign of respect, the tradition was to reserve certain quiet places and to designate particular caves, hills, and forests for their high-god. These places were out of bounds for the general population. Even the priests or the intermediaries had an established protocol for approaching the higher One. The traditional Africans were like the Athenians who had "objects of worship" but confessed in their inscription that they did not really know the God they worshiped (Acts 17:22-23). Like apostle Paul to the Corinthians, the missionaries to Africa brought more light of the Supreme Being whom the Africans already recognized and worshiped as unknown God (Acts 17:24-34). God's existence was never an issue to an African.

The traditional Malawians had religious practices connected with the rites of various passages including birth, purification, and death. They also had their worst fears towards causes of diseases, sorcery, and witchcraft. In response to these fears, there were African herbal medicine doctors who had plain prescriptions for various diseases as well as giving charms for good luck and protection. There were also aspects in some of their rites that had religious practices.

\section{Myths about God and Human Sufferings}

There are different myths suggesting what triggered human suffering. All African myths seem to suggest that once upon a time, there was harmony between the people and

${ }^{1}$ Johnston, Robert Laws of Livingstonia, 1935 (?), 75. 
the higher being. Something terrible happened to disrupt the relationship. As a result, the broken relationship ushered in suffering and death.

Among the Chewa, the largest Bantu group in Malawi, their Kapirintiwa myth states that human beings accidentally discovered fire and used it to set the bush ablaze. The fire forced God to withdraw to the sky, thereby creating a deep chasm. Resulting from this event, the Creator passed a death decree with a view to bringing the dead closer to him. ${ }^{1}$ This Malawian myth seems to go well with a belief in the spirit world that the departed loved ones, "enter another existence." It is therefore, no surprise that many have embraced doctrine that the dead change into another form and go to heaven soon after death.

These myths fall short of the biblical teachings on the state of the dead. They seem to portray death as another state of consciousness contrary to Christian scriptural teaching that the dead know nothing and cannot participate with the living (Eccl 9:5-6; Job 14:21). Again, the traditional belief lacks the biblical teaching of resurrection (John $11: 25 ; 14: 1-3 ; 1$ Thess $4: 13-18)$. As such, traditional belief has no clear solution to the sin problem. The Christian belief is appealing because it offers a superior solution to the sin problem and addresses the traditional preoccupation with fear. The resurrection promises life beyond the grave and an absence of $\sin$.

African myths confirm the existence of a supernatural being who once lived in harmony with the people. They also show that people were responsible for his departure

${ }^{1}$ Augustine C. Musopole, Being Human in Africa: Toward an African Christian Anthropology (New York, NY: Peter Lang Publishing, Inc., 1994), 71.

${ }^{2}$ Rolf E. Aaseng, Reflections in a Mission Mirror: Ancient Wisdom from Younger Churches (Minneapolis, MN: Kirk House Publishers, 1998), 41. 
from their midst because of human sin. This understanding is very important for disciple makers. The knowledge exposes the ugliness of $\sin$ and the damage it has made. On the other hand, harmony with God calls for total obedience to Him. Trained and nurtured discipleship can enlighten these powerful traditional African myths about the God who yearns for the return of the sinner to once again fellowship with Him.

\section{Fear and Witchcraft Culture}

The belief in witchcraft is universal. Even the nations noted for their civilization have not been exempted from incidents of witchcraft. During Cromwell's era, between three and four thousand people suffered death for witchcraft in England. ${ }^{1}$ In a preChristian African mind, illness and death are not natural or accidental happenings. There is always a cause and effect. They were believed to be caused by a power or a witch (mfiti). While the Western approach to disease is to conduct more scientific research to conquer it, Africans have a passion to find "a cause for every effect."2 The traditional African approach was to deal with the causative agent and fight to get rid of the enemy. Africans put much of their effort on identifying the causative agent. ${ }^{3}$ A witch was considered cruel and an unkind enemy. The way of identifying and dealing with such persons was unreliable, biased, and cruel, too.

According to tradition, the elderly and the rich people were the first suspects of witchcraft. Their crime was to have more than their peers. The elderly had more years of

${ }^{1}$ Frank Debenham, Nyasaland: The Land of the Lake (London, Great Britain: Her Majesty's Stationery Office, 1955), 168-169.

${ }^{2}$ Tbid., 170.

${ }^{3} \mathrm{Ibid}$. 
life and the wealthy had more possessions than their counterparts. The conclusion was that they were both steeped in magic. Such people were to be taken out of the society.

The British government engaged the services of Dr. Mitchell, the director of the Rhodes-Livingstone Research Institute, to tackle the witchcraft problem in Malawi. He advised the government to adopt a sympathetic stance instead of sending the diviners to prison. In tackling the problem, his conclusion was that "the native believes in sorcery because he must have an explanation for every happening; he is not content with saying, as we do, that it was just bad luck that the branch of the tree broke and the man was killed, or that it was pure chance that one man got tick disease and the man next to him did not"1

The culture and practice of witchcraft continues to this very day. Once in awhile it surfaces in an unbelievable manner. Recently, it was reported on-line that Divasoni, who was in police custody at Chichiri Prison in Blantyre, turned into a "leopard, lion, a monkey and a snake." Allegations went further to say that he attacked other prisoners. The belief in sorcery interlocks with the people's "moral code and social justice."3 To them, justice is done when persons who cause illness or death are adequately punished. The traditional punishment was to give the alleged mfiti concocted herbal poison (mwavi). ${ }^{4}$ The poison was also administered in trial cases of rape, adultery, theft, and other crimes. Many innocent people were killed by this poison.

${ }^{1}$ Ibid.

${ }^{2}$ Gideon Munthali, "Remandee turns into lion, leopard, snake, monkey," http://www.nationmalawi.com (March 23, 2006).

${ }^{3}$ Debenham, 170-171.

${ }^{4}$ Duff, 319 . 
Basically, sufferings were understood to be the result of sin or violation of code of conduct which drove God away. ${ }^{1}$ This kind of thinking was not only confined to Malawi. As already said, it was also cherished by others in Africa and elsewhere. Richard Gray concurs that according to traditional thought, evil meant that God was either at a distance or provoked by "one's own behaviour when taboos are broken, or by the wishes and actions of sorcerers or witches. In both cases, ethical values are involved. Selfishness, the neglect of the rights of other people whether living or dead, adultery, the destruction of categories, all these could provoke punishment by ancestral and other spiritual powers."2

In short, the African traditional religious belief system embraced a faith in one invisible, all-powerful supreme being, and provider of their needs. Ancestral spirit mediators were what Abraham, Moses, Samuel, and the host of the prophets were to the children of Israel. While the Israelites had a direct access to God, yet they looked to these patriachs and many others like mediators. The people held these great men of their time in high esteem. It is with this same line of thought that Africans revered certain people as their mediators. With mfiti, people's response was out of fear not respect. Mwavi was meant to cleanse all $m$ fiti from among the people. It was like purification of the society.

\section{Purification as a Moral Duty}

In the Old Testament, discharge of blood including customary monthly periods

${ }^{1}$ W. Meredith Long, Health, Healing and God's Kingdom: A New Pathway to Health Ministry in Africa (Harrisonburg, VA: R. R. Donnelly and Co., 2000), 7-9.

${ }^{2}$ Richard Gray, Black Christians and White Missionaries (New Haven, CT: Yale University Press, 1990), 102. 
rendered a person impure for seven days (Lev 15:19-28). Abstinence from sex was also required during war time. Uriah refused to go home and spend a night with his wife while the ark, Israel, and Judah were sleeping in tents (2 Sam 11:11). War and sacrifice were critical events when people needed to focus on the business of the community.

For a traditional African, sex was unthinkable in times of war or worship. These were times of self-examination. It was time for deep heart-searching. Purification (chiyero) and abstinence (kudziletsa) were required during traditional sacrifice time. This meant sorting out any inter-personal misunderstandings and more importantly, abstinence from sex. Failure to do so, would be an invitation for woes, curses, and even death itself.

Traditional leaders were very strict about abstinence. They were convinced that an unclean state would hinder the communication with the high powers. In fact, Pastor Francis Sibande remembers that the whole village was required to observe sex abstinence particularly when the elders went to offer sacrifices to the high god. ${ }^{1}$

Even today, pregnant women, feeding mothers, or any female experiencing monthly periods are assumed unclean to participate in a communion service. This partly contributes to low census during communion services. In their mind, it resonates with Paul's warning to the Corinthians that "anyone who eats and drinks without recognizing the body of the Lord eats and drinks judgment on himself. That is why many of you are weak and sick, and a number of you have fallen asleep" (1 Cor 11:29-30). Realizing this tradition, it is therefore important for modern Christian disciples to know and differentiate Christ's pure gospel teachings from cultural traditions. Like Peter, the

${ }^{1}$ Francis Sibande, a Malawian retired gospel minister, interview by author, December 22, 2005, Berrien Springs, MI. 
disciples will be called before the earthly authorities where they will need to declare their firm belief and unflinching allegiance to God (Acts 5:29).

\section{Bridges to Discipleship}

Generally, Africans are grateful for the pioneer missionaries who brought them the gospel. While this is true, they have also come to realize that their cultural felt needs were not seriously considered at the time the gospel reached them. Voices are being raised for "an authentic African form of Christianity which could in its turn enrich all the Churches of the world."1 One question to ask is how far the church can go to incorporate African rituals and still be faithful to the Scriptures? The African request is not to baptize their culture and customs back to back. Roger Bowen understands the African quest to be for a supply of Christian rituals, preservation of innocent African traditions, empowerment of local churches to decide what to adopt or discard, and to take people's beliefs seriously instead of dismissing them without a strong scriptural backing. ${ }^{2}$ Apparently, the indigenous African churches provide the felt needs and are attracting more people from the mainline churches. ${ }^{3}$

However, the reason behind the argument is not simply a matter of retaining the rituals. The purpose is to use the approved rituals as bridges in the task of making authentic disciples who are truly loyal to Christ's gospel. Effective disciples need to have a genuine conversion experience which shows itself in their conduct be it in public or

${ }^{1}$ Ibid., 151.

${ }^{2}$ Tbid., 149.

${ }^{3}$ Roger Bowen, . . . So Send I You: A Study Guide to Mission (London, Great Britain, 1998), 149. 
private. A positive attitude towards cultural felt needs of the disciples would enhance disciple-making in Malawi. Again, the approval is for the rituals that are not in any way contrary to biblical standards. Such rituals could be used to deepen individual or corporate Christian experience of the people.

A Consecration Ritual Bridge. Indigenous Malawians had different rituals and symbols. Some of the rituals were performed to protect their own lives, animals, and produce from the fields. They had a strong belief that evil people would use magic to cause physical harm or rob their produce. To avoid this from happening, there was a ritual called kutsirika. The ritual was performed silently or with chanting while applying some herbal medicine on all the four corners of the field before planting. New homes, commercial buildings, and maize mill installations were subjected to this ritual. The Bible condemns abominable customs like kutsirika (Deut 18:9-14).

The Christian church can set special days at the beginning of a planting season for a biblical blessing ritual of the fields. The consecration ritual could be composed of pertinent music, Scripture reading, a sermonette, a litany, consecration prayer for the people in which the petitioner asks for God's blessings of health, protection, good rains, and harvest.

Such a consecration ritual would make a powerful impact on the whole community. The ritual would also build people's faith in God's omnipresence and omnipotence. It would presumably take care of their fear of witchcraft. This could probably minimize and prevent people from the temptation of living two lives, one on Sabbath and another for the rest of the week.

The consecration ritual could also be performed for new houses, commercial 
buildings including maize mills as needed by the people. The members including the new disciples would be educated so that performance of consecration ritual is at their request.

The SDA Minister's Handbook has suggested rituals for groundbreaking and house opening. ${ }^{1}$ Unfortunately, they are not performed for individual members in Malawi. They have never been part of the church practice. The church is very suspicious of any new practices. They are viewed as apostasy. This attitude includes memorial services in commemoration of the members who may have died and were buried away from home.

\section{Chain of Command}

It is an accepted saying that "anthropology begins at home." The home is part of the community. The chain of command in the home and community is reflected in other institutions like the church. In general, an African chain of command is almost considered sacred. In the home, the father is the ultimate authority while the community leaders have their powers within their jurisdictions. African Christians regard these offices with respect (Eph 6:1-3; Rom 13:1). Anyone who fails to recognize the chain of command is called wopanda mwambo meaning uncouth, without customary manners.

Sometimes, the traditional chain of command becomes an impediment to growth and progress. It closes the doors of openness and alternatives. It becomes a source of clashes among various groups of people including Christians. A secular chain of

${ }^{1}$ General Conference of Seventh-day Adventists, Minister's Handbook (Silver Spring MD: Ministerial Association, 1997), 243-248.

${ }^{2}$ Kenyatta, vii. 
command can be intimidating when it spills over into matters of religion. Some pastors and members do not seem to know how to relate to high ranking community leaders. The tendency is either to ignore or over-recognize them in laborious introductions. Some dignitaries dread going to church because they dislike repeated introductions. ${ }^{1}$ It can be confusing to new disciples and it needs to be addressed.

There seems to be unexplained tension in the church emanating from exchange of roles between the community leaders and the ordinary church members. Members seem to be uncomfortable serving in a church office where traditional leaders like chiefs and politicians attend. There is unexpressed feeling of fear and intimidation. People may not say it out loud, but fear of witchcraft could not be a far-fetched idea.

The above dilemma makes it imperative to have discipleship that is tailored to the sensitive and silent Malawian culture. Pastors, church members, and community leaders need re-orientation into church life where all give due respect to various offices but at the same time stand equal before God (Gal 3:28).

In Malawi, the religious chain of command has been borrowed and adopted from the cultural practices. For example, the tradition of go-betweens is an indispensable part of the respected practice in the Malawian culture. In this regard, the concept of the midperson was incorporated in religious traditional services.

${ }^{1}$ Hon. Edward Bwanali, Member of Parliament, a cabinet minister, and my personal friend did not want special place or recognition in the church. He was there to worship like anybody else. 


\section{A Go-Between Culture}

The concept of a go-between forms the basis for the approach traditional religion took in matters of worship. Malawian culture places much emphasis and importance on the office of the go-between (nkhoswe). It is a common practice in a family for children to make their requests to the father through their mother. In the matrilineal family system common in Malawi, your mother's brother is a very important person. He is automatically your nkhoswe. He features highly during family events like weddings. $\mathrm{Be}$ it a traditional village wedding or a Christian church wedding, a go-between is indispensable.

A relationship between a young man and a young woman is seen as nothing more than child's play (masewera a ana) until the two approach their ankhoswe (plural). The groom's go-between meets with the bride's go-between and officially asks (kufunsira/kupempha) for marriage on behalf of the young man. When this is done, the relationship becomes an adult matter (nkhani ya akuluakulu). Once in awhile, ankhoswe withdraws if insulted by the couple or one of them. Sometimes, one family may disapprove of marital plans. Any decision to ignore and co-habit renders that relationship insecure. In short, there is no marriage without ankhoswe.

Ankhoswe finalize and seal a marriage contract and in church weddings act as official witnesses. They do everything including signing marriage certificates. In the matrilineal system, the bride is given away by her nkhoswe. After the marriage consummation, ankhoswe serve as primary counselors and are responsible to settle any differences in that marriage. They stand with the couple in both good and bad times. Ankhoswe have saved many marriages from breaking up. 


\section{Nkhoswe and Cultural Respect for the Elderly}

Culturally, an African young person does not look in the eyes of an elderly person. This would be great disrespect. When a younger person wants a serious discussion with an elderly person, he or she will engage an equally older person or that person's friend to be a mouthpiece. This shows sincerity and respect for the person you could not talk to directly. In most cases, the request is more likely to be granted because of the relationship between your nkhoswe and the person.

In keeping with culture and tradition, Africans found themselves carrying this gobetween concept into matters of religion. They worshiped through living mediums or the spirits of the dead. The spirits of the venerated dead, stood between the living and the super being. Msiska explains it so well. "Each tribe, each clan, each household could worship God through a well known relative who understood their needs. No one could approach the chief in a village without first going to his messenger; the messenger then went to the counselor, who then consulted the chief on behalf of the man in need. It may be that the chief would see the man personally, but it was always by the will of the chief and not the suppliant. Children consulted their mother about their needs. This was an honour to the father or chief. "So how much more to the Creator."

In times of plagues, droughts, famine, war, and other calamities, the African forefathers cried to a higher being through intermediaries. They sought Him whenever they were faced with "trouble, pain, disappointment and death."2 They also remembered Him in times of peace, happiness, joy and celebrations. The whole village came together

${ }^{1}$ Msiska, 24.

${ }^{2}$ Ibid., 20. 
after harvest when the priests or leaders of worship (basofi) took people's needs through the vehicle of the higher spirits (vipiri) who were regarded as men of authority and unquestionable reputation. ${ }^{1}$ The higher spirits (vipiri) communicated the needs of the people to the high God, Chauta, Chiuta, Mulungu or Mlengi, Leza.

The African worshiper is overwhelmed by this greatness of the supernatural. It is a wonder, an unexplainable mystery. Since God cannot be seen, He remains a mystery. He is not our equal. He is a higher spirit than the highest of the spirits including venerated ancestors. They approached Him with a sense of humility, awe, and much reverence. This unapproachable being needs others of file and rank to be our intermediaries. To this end, the African religion engaged spirits from their vast spirit world. The medium could be a possessed living person, an ancestor, a domestic animal, a tree, mountain, or any object.

When Christianity came to Africa, it was clear that, "Jesus is not just the greatest of our vipiri or higher spirits; but he is God among men. He has come to live among us, and the whole hierarchy of our ancestors has lost its traditional meaning; this is to say that in Jesus Christ we have no need for any other intermediary between God and us. He is all that we need for our fellowship with him. This is what is new in the message of Christ."2

The nkhoswe culture could help or hinder discipleship. It could be helpful in terms of its nurturing aspect especially in a marriage relationship. The first years of marriage can be rough because a couple continues to learn of each other closely. This is usually the time when ankhoswe are called often to counsel the new couple. Similarly, a

${ }^{1}$ Ibid., 25.

${ }^{2}$ Ibid., 33-34. 
new convert has so much to learn and unlearn during the first years of a spiritual journey. Discipling system can prove to be helpful during this time. New converts need much support from the experienced members at the beginning of their relationship with Jesus.

The weakness part of the nkhoswe culture is that it does not have a cut point. There is no defined period when a couple may be said to be mature enough not to rely on outside counsel. Too much co-dependance on ankhoswe, prevent them from developing their own problem-solving skills. If this culture extends to discipleship, there is danger that the new converts will not attain maturity. In this way, it could hinder discipleship goals besides relying on people instead of Christ. After all, the Holy Spirit is an Advocate (John 16:8 NEB). The Spirit understands and interprets our groans, and puts them into the language of heaven (Rom 8:26 NEB).

\section{Communication Bridges to Discipleship}

Malawians have a high sense of respect for the elderly. Women kneel and men squat when greeting elderly persons. According to Msiska, this is one area where "Malawians gain a high reputation among visitors and it is a gift from God himself." This respect can also be noticed in the churches where the children sit quietly on the floor for more than one hour during the worship service. The communities have ways of respecting and celebrating their elders even after their death.

Non-Christians in some parts of Malawi used to take a weekend to celebrate the death of their deceased family members and friends. They had traditional dances and beer-drinking with sounds of drums about a year after death. The Moslem communities

${ }^{1}$ Ibid., 47. 
have a similar celebration called sadaka, a festival in commemoration of the dead. These rituals are part of the mourning process. They are the last acts of respect given to the dead. The whole community is involved. Christian family members may not dance or brew or drink beer, but sometimes they contribute grains for a home-made beer drink.

The whole idea is to publicly and respectfully close the chapter of the dead persons. Having done this, people feel relieved and happy to have paid their debt to the deceased. When the church fails to offer these felt needs, the members feel unnecessarily alienated from their family and society. Some of them participate in the rituals, especially sadaka, and claim not to have been part of the rituals even if they were performed in their family. The church could pretend to be blind to what is taking place. These are practices that hinder the witness of the Christian church.

Disciples are to be made from these Malawian societies steeped in rituals. The church has to avoid syncretism and at the same time know that as Konrad Raiser wrote, "Cultural and ethnic identity is a gift of God." To ask the new disciples to totally disown their cultural identity is but placing a burden on them. It would be a contextualization failure and mission tragedy.

People have to forsake their incompatible old ways. New alternatives can be found to celebrate their newly found faith, and consecrate their lives so that they can daily honor and glorify God. As bridges to discipleship, the rituals are part of the nurturing process while at the same time meeting the needs of all members in the church. In so doing, the church follows the example of the early disciples in their handling of the

${ }^{1}$ Konrad Raiser, "Opening Space for a Cultural Dialogue and Solidarity: The Missionary Objectives of the WCC in an Age of Globalization and Religious Plurality," International Review Mission (July 1999): 204. 
circumcision issue for the Antioch converts (Acts 15).

An Intercessory Prayer Bridge. The church could create an intercessory prayer ritual for the "prayer-warriors" to participate in a full ministry which could facilitate disciple-making strategy. Such a ritual would replace the unchristian practices and at the same time meet the needs of the members while molding and producing authentic disciples.

God has promised to answer intercessory prayers (1 John 5:16). The prophet Samuel interceded for the children of Israel even after being rebellious when they asked for a king (1 Sam 12:23). Daniel prayed and fasted for the sins of Israel (Dan 9). Jesus interceded for His original and all disciples (John 17). Christ continues to intercede in heaven on behalf of His earthly children (Heb 8:1-2; 1 John 2:1-2).

A Celebration Ritual Bridge. The church can introduce a Christian celebration ritual and articulate its beliefs about death and its hope beyond the grave. The ritual would meet a felt need of the new disciples from the Muslim communities. It would also pave the way for people from the Moslem background to accept Christianity without completely severing ties with their families. This would enable them to influence their immediate and extended family members and friends in the community. Again, the celebration ritual would not be mandatory.

A Wedding Ritual Bridge. There are many members who are not able to have church weddings because of expenses. The church has tried to encourage simple weddings but it has not received much success. As a result, traditional weddings are common among the church members. Usually, a traditional wedding has general

${ }^{1}$ Paul Y. Cho, Prayer: Key to Revival (Dallas, TX: Word Publishing, 1984), 80. 
marriage counsel, a feast, and traditional dances. The bride and groom begin their family with no church blessing.

A wedding ritual composed of a sermon, prayer, simple vows, and a consecration prayer could enhance discipleship strategy in Malawi. This could be done without any compromise of the church principles. The ritual would take place right in their community. Such a ritual can be a great blessing to the couple and their communities.

\section{Traditional Forms of Discipleship}

Although culture is said to be changing with time, there are still some striking similarities between Malawi and the culture of the people depicted in the Bible at the time of its writing. This is clear in the Old Testament narratives. Malawi has several forms of traditional discipleship. These traditional discipleship models have helped to keep the rituals, rites of passage, herbal medicine, craft-making, rulership succession, and others. As for the place of women, the New Testament sounds so much like Malawian culture.

Culturally, whenever old people went on a trip, they traveled with a bag carrier (wotenga thumba), usually a young person. Such trips provided a productive time for the young companion to learn important lessons on core virtues that make a person. For a young person, it was deemed a highest honor to be selected among others to travel with a reputable older person. Once the younger person won the heart of the older person, it was the beginning of an informal mentoring relationship. The young person was expected to behave well in the presence or absence of the mentor. Any serious acts of misbehavior were reported to the mentor. It was the mentor's obligation to warn the mentoree. Failure to change, was a ground to be disqualified from further travel privileges.

This discipleship model was one-on-one although occasionally a general counsel 
would be given to more than one. The learner passed on the skill or knowledge to another person within the tribe. In this way, a family trade survived from one generation to another. A skill was regarded as a rich inheritance. The whole family or clan took pride in that inheritance because it benefitted everybody. People did not want the skill to die with them. Unless it was a premature death, any person who did not make an effort to pass on the skill was considered a jealous person (munthu wanjilu). Such individuals passed on to their graves with no pomp and honor. Rulers prepared possible successors.

\section{Chieftainship Preparation}

The practice of finding a successor differs from one tribe to another. A nephew or the son of the incumbent is usually the heir to the throne. However, there were exceptions to the rule. In the absence of a rightful male heir, succession rules changed. In some cases the heir to the throne had employment and did not want to leave the job for traditional rulership until retirement. In such situations, the council members (nduna), advisors to the chief waved the rule, but in consultation with the royal family. Whoever was appointed knew that it was temporary arrangement.

African chieftainship succession is not always automatic. At the same time, although succession is not a clear-cut case, it is not decided at the ballot box either. There are several factors like being a rightful heir, good character, and sound health. If in the estimation of the nduna, the person in line fell terribly short especially on character, they considered the siblings like in the case of David (1 Kgs 16:6-13). But, once the decision is made on the successor, the incumbent prepares that person. This is where formal discipleship begins. The young apprentice becomes a child of the bosom (mwana wa mkhwapa). Although there is no structured training program, the prospective 
successor is taught about rulership including how to deal with land issues.

At the village court, the apprentice sits near the ruler to observe the traditional way of handling cases (milandu). In case of death of the incumbent, there are no gaps. The constituent $n d u n a s$ work closely with the young person. The system provides and ensures a smooth transition of power. After about a year of acting, they arrange for coronation of the successor. The coronation seals the questions of legitimacy, character, and leadership ability.

The wisdom of the whole system was in the council members who helped to prepare the successor and continued to guide that young ruler until they were satisfied. But even then, they did not completely leave the ruler on his own. They always made their input in all major decisions. In fact, these are the people who judge cases in the village. Much of their work is done behind the scenes. They are the main body involved in discipleship of new heirs. They censure and reprimand leaders for acts of misbehavior. The model has a nurturing process that would be incorporated in disciple-making.

\section{Celebrated Counselor (Nankungwi)}

Nankungwi is usually an elderly woman deemed to be wise, experienced, and a highly respected person in the society. Her main work is to instruct young girls in matters of traditional nature and behavior after reaching puberty. On the male side, the instructor especially in the central region is known as phungu. The chief duty of nankungwi/phungu is to give pertinent counsel (mwambo) connected with the rites of passage.

Nyau is a male secret society practiced in some parts of the central and the southern regions. The society practices initiation rites. The Nyau initiation rites do not require circumcision. They are known for their strict discipline, wearing of masks, and 
their traditional dance called gule wamkulu, meanig the dance of all dances.

No person was born a counselor. There was a process through which counselors were made. Adequate preparation of such a person involved extensive coaching. Certain rites required the learner to be kept indoors under quarantine (kubindikira). ${ }^{1}$ The person was cut from all possible distractions. This was a critical testing time for the learner. It was to show one's determination and resolve to be made into whatever the society desired. The isolation period was a time for soul-searching emotionally, mentally, and socially. The only people allowed to visit allowed were those who had already been initiated into this particular rite of passage. Anybody not initiated was like an uncouth.

\section{Discipling an African Medicine Doctor}

Healing is a gift from God. It is also a spiritual gift (1 Cor 12:28). In the Old Testament, God prescribed "a poultice of figs" to cure Hezekiah of his boil (2 Kgs 20:7). In the New Testament, Jesus mixed saliva with mud to heal a blind man (John 9:6-7).

Africans have from time immemorial used herbs to treat diseases. They had no illusion about the source of healing. They realized that the actual healing came from God. This realization was partly the reason not to charge. There was no cost levied on the actual medicines. If they charged, it was a token charge known as chipondamthengo, literally meaning "for setting foot in the bush." This is like a consultation fee. It was paid after healing. Times have changed. The African herbalists have gone commercial.

African medicine does not have a prescribed study program like the Western system. It is a clear case of traditional discipleship. The herbalist takes a well-behaved

${ }^{1} J$. B. Kuthemba Mwale, "Re: Material for Research on Discipleship," e-mail sent January 27, 2006. 
young person, usually a relative. The person is shown one or different herbs and trees with medicinal value in the roots, leaves, or the bark. This introduction is like an orientation. There were times when the whole day was spent in the forest in search of medicines to dry and store them. The mentor-herbal doctor knew where to find different medicinal herbs. If the learner had writing skills, he or she took notes with details of where to find the herb, its preparation, mode of administration, and dosage. The trainee was taught the art of mixing several herbs as well. In addition, the training included public relations with the people. Good relations were vital in any trade.

Sometimes the herbalist sent the trainee into the bush alone to get the needed medicine. This was the time to test one's memory. When the medicine brought by the trainee healed the patient, it was concluded that the assistant had dzanja labwino, a "good hand," just like the westerners talk about a "green thumb." With time, the training process built confidence not only in the learner but in the clientele as well. The community embraced the budding herbalist as their own.

Some herbalists are experts. ${ }^{2}$ They specialize in certain diseases like seizures, mental illness, stomach problems, migraine headaches, snake-bites, and so forth. Azamba, women traditional birth attendants, are in this category. Azamba are traditional midwives. They assist with baby-delivery, handling of umbilical cord, and any other related services. They serve hand-in-hand with anankungwi and the herbalists. Others

${ }^{1}$ Martin Lisirira of Chimwankhunda, Blantyre, Malawi, telephone interview; January 15, 2006.

${ }^{2}$ Fraser, 140. 
specialize in a ritual of releasing the mother and a newly born baby (kutulutsa chikuta) from isolation. ${ }^{1}$ The ritual involves some medication on the baby's anterior fontanelle and umblical cord. The mother returns to a normal life of activities and carries the baby around on her back. Those specialized African herbalists can be compared to the giftoriented ministries for the disciples. Interestingly, it requires much experience to have a specialty in certain diseases. People know these specialists and their field of expertise.

African medicine is a valuable family inheritance and has changed hands from generation to generation. Writing on what was then known as native medicine, David Livingstone, a distinguished missionary pioneer and explorer made the following observation, "Those doctors who have inherited their profession as an heir-loom from their fathers and grandfathers generally possess some valuable knowledge, the result of long and close observation but if a man cannot say that the medical art is in his family, he may be considered a quack."2

In recent times, there have been workshops to facilitate a dialogue between Malawian traditional herbalists and the western medicine practitioners. There is exchange of information. The dialogue has helped greatly to shed off negative aspects of traditional African medicine. It is an on-going education process. Today, there are national and regional associations of herbalists. The once condemned form of healing is now being recognized for its worth worldwide.

These examples of traditional forms of discipleship are an advantageous link in

${ }^{1}$ Liness Lisirira of Chimwankhunda Township, Blantyre, Malawi, telephone interview, January 15, 2006.

${ }^{2}$ David Livingstone, Missionary Travels and Researches in South Africa (London, Great Britain: Ward Lock \& Co. Limited, 1910), 114. 
the quest to make disciples of all nations. They give church members a point of reference. It is something they know and are able to relate to. Most of the members have actually gone through these traditional rituals and they value their experiences.

Since traditional forms of discipleship have enjoyed a measure of success, Christian discipleship strategy can have the same and even more success provided there is real commitment. Joseph Mwale makes helpful observations and analysis of the traditional discipleship models as to why they succeeded.

All these succeed in making their students real disciples and the transition from/to or the effectiveness of the training is evident in the students who are usually mirror images of their teacher/master. There are a number of reasons why these traditional forms of discipleship succeed: First, the students are isolated in seclusion during the critical part of their training, just as Christ took his students away from the normal social settings; Secondly, the teacher/master and students share a lot in common from the belief system, goal of traveling, survival value and the indispensability of the skills and knowledge they acquire for their survival and fulfillment of their cause. Third, all society around them shares the need for such education, they support it, encourage the students in all possible ways and endorse the necessity for youth to acquire those "survival" skills and the indispensable knowledge; fourthly, all traditional forms of discipleship are inherent in the traditions and culture of that society ...; fifthly, the teacher/master in the traditional settings sustains the disciples just as Jesus did. He protected them, fed them, owned them, really loved them and was very truthful. ${ }^{1}$

\section{Bridges to Succession Discipleship}

Healing ministry is a part of the Gospel Commission. Jesus performed many miracles that were not even recorded in the Bible (John 20:30-31). When Christ sent His twelve disciples on a mission to preach the gospel, He also "gave them authority to drive out spirits and to heal every disease and sickness" (Matt 10:1). The apostles performed many healing miracles resulting in many people turning to Christianity (Acts 5:12-16).

\footnotetext{
${ }^{1}$ Joseph Mwale, "E-mail communication in response to my inquiry on Traditional
} Forms of Discipleship," January 27, 2006. 
The Lord enabled the apostles to perform miraculous signs and wonders as His way of confirming the message of His grace (Acts 14:3). In fact, the elders can be the agents of healing. They are encouraged to pray and anoint the sick (Jas 5:13-16). The prayers of the righteous are powerful and effective. God's healing is holistic not just physical.

As already pointed out in this paper, healing is a gift. There are possibilities of abuses but they are not to completely stop Christ's disciples from exercising the gift. It is one way of making disciples. Healing is not an end in itself. It points to the love, goodness, and power of the greatest Healer, Christ Himself. It strengthens people's faith. As a task of disciple-making, the church in Malawi can provide on a more regular basis, a Bible-based healing ritual. This would not violate any biblical principle on healing.

Healing and Anointing Ritual Bridge. This ritual is not common among the church members. It is rarely performed and as a last result when all hope of life is completely gone. As a result, when people hear about anointing a sick person, they think it is a statement of death itself. It is no surprise, they dread and greet the idea with fear.

The ritual needs to be administered not as a last sacrament to the dying. It is to be kept short but solemn. It demands faith and confession of sins by the patient and the participating members. The ritual includes reading relevant scriptures, prayer, and anointing the patient's forehead with olive oil. The oil "symbolizes the Holy Spirit touching the afflicted one in a specific and special way."1

Like other rituals, it is to be administered when requested. Depending on the circumstances and condition of the patient, it could be requested by the sick person, family members, or close friends. The church needs education. The small number of

${ }^{1}$ Seventh-day Adventist, Minister's Handbook, 257. 
people who have requested anointing have done so when everything else has failed and the patient is at a point of death. In this way, the ceremony is associated with death.

The Pentecostal churches have won many members of other churches including Adventists because they provide a healing and anointing ritual. "It is our work to present the sick and suffering to Christ in the arms of our faith. We should teach them to believe in the Great Healer. We should lay hold on His promise, and pray for the manifestation of His power. The very essence of the gospel is restoration, and the Saviour would have us bid the sick, the hopeless, and the afflicted take hold upon His strength."1

\section{Status Orientation}

Malawi is among the world's least developed countries. Economically, the country is agriculture-based. About 90 percent of the population lives in the rural areas. ${ }^{2}$ The people are mostly small-scale peasant farmers. The country relies heavily on external financial assistance from individual donor countries and financial institutions like the International Monetary Fund (IMF) and the World Bank. ${ }^{3}$ Like other African countries thirty years ago, social classes were not rigidly developed due to kinship links which cut across status distinctions. ${ }^{4}$

Malawian families can best be described as male-headed households. Tradition has been insensitive to equality of all people. According to Hendry, gender is an ascribed

\footnotetext{
${ }^{1}$ White, The Desire of Ages, 824.

2“"Malawi," http://cia.gov/cia/publications/factbook/geos/mi.html (January 25, 2006).

${ }^{3}$ Ibid.

${ }^{4}$ Harold D. Nelson, Area Handbook for Malawi (Washington, DC: Foreign Affairs Studies (FAS) of the American University, 1975), 89.
} 
status. ${ }^{1}$ Nobody chooses what gender to take. There is nothing evil about gender. Unfortunately, all over the world, women seem to be the victims of gender bias. There is always a temptation for men to suppress women. Traditional attitudes toward women are slowly changing. Christianity, education, and travel are among the major players of these changes. Very recently, the political environment has become a contributing factor.

An extended family is a complex of relational kinship network. Hiebert says that class orientation is either ascribed by virtue of birth or achieved as a result of choice and effort. $^{2}$ Traditionally, class orientation in Malawi has been a result of birth. There was not much one could do to change from one social class to another. Occupation and economy, which are the two major factors in class placement, ${ }^{3}$ do not really apply in rural areas. Chiefs are the traditional rulers and are in the upper class of that community.

A less democratic community places more value on birth status. It restricts status mobility. People tend to think of classes they were born into as non-negotiable. One Malawian artist has a song "Apatsa mosiyana" meaning "God gives differently." The thinking behind this song is that God decides status at birth. This being the case, no matter how hard one may work, it does not make any difference. This school of thought

${ }^{1}$ Joy Hendry, Other People's Worlds: An Introduction to Cultural and Social Anthropology (New York, NY: New York University Press, 1999), 177.

${ }^{2}$ Hiebert, Cultural Anthropology, 151.

${ }^{3}$ Leigh Marlowe, Social Psychology: An Interdisciplinary Approach to Human Behavior (Boston, MA: Holbrook Press, Inc., 1975), 379. 
kills the spirit of hard work and high aspirations. The system does not encourage achieved statuses. According to Joe Hendry, achieved statuses are only valued and provided by truly democratic societies. ${ }^{1}$ True democratic society provides a conducive environment for achieved statuses.

In Malawi, family background, education, business acumen, religion, and marriage are some contributing factors which influence class orientation. In some cases, rituals are still a major factor for class orientation. Puberty and male circumcision rituals are good examples of this upward class mobility. They do not, however, change the stratum of the individual in terms of income. But the society attaches value to these critical rituals. Harry Mtike confirms in his dissertation that the whole premise of male circumcision (mdulidwe) is to separate men from boys. ${ }^{2}$ The perception is that you posses virtues not available to the un-circumcised (osadulidwa kapena osabvinidwa).

The rites of passage have elements of separation and incorporation. ${ }^{3}$ The crucial phase of a ritual is during separation. Interestingly, Conrad Kottak uses a spiritual terminology to say that sometimes, status change "requires conversion experience."4 A ritual does not only change one's status but also the heart and whole behavior. The separation phase is part of the process to move from one class to another.

${ }^{1}$ Hendry, 177.

${ }^{2}$ Harry G. Mtike, "A Christian Approach to Traditional Male Circumcision Customs in Malawi” (D.Min. dissertation, Andrews University, 1999), 42.

${ }^{3}$ Nigel Rapport and Joanna Overing, Social and Cultural Anthropology: The Key Concepts (London, Great Britain: Routledge, 2000), 230.

${ }^{4}$ Conrad Phillip Kottak, Cultural Anthropology, $8^{\text {th }}$ ed. (Boston, MA: McGrawHill, 2000), 115. 
In recent times, Malawi has experienced a significant population shift from rural to the townships and cities. In this development, occupation and economy have been factors in class orientation. Urbanization has ushered in new challenges not only in the delivery of health and other social services, but more importantly on discipleship strategy.

One question to answer is what do these social stratifications have to do with discipleship? There are dynamics in the church today because of these social classes in the communities. Solomon's befitting counsel for clergy is: "Be sure you know the condition of your flocks, give careful attention to your herds" (Prov 27:23). Knowledge is power. It helps to do an task with conviction. Knowledgeable people plan are able to stand for right causes.

The fluidity of class orientation brings some merits to the composition of membership. Once people move to urban areas, they find it easier to change their faith on account of conviction. Their achieved new social status does not need parental support anymore. In fact, if anything, there is a reverse of roles. Parents are the ones who may need the support. Some parents have found the truth and changed churches because of the influence from their children.

Paul talks about giving new converts enough training and time to mature before becoming church officers (1 Tim 3:1-13). This shows that Christian discipleship has some mobility. It will not change a class as such, but the quality of Christian life and responsibility. It allows growth. This warning could also be made that Paul does not want the churches to unnecessarily withhold church offices from the tested and gifted new converts. They are to be recognized with offices based on the demonstration of their abilities and spiritual maturity. 


\section{Class Classifications}

Class stratification in Malawi may be debatable. However, there are probably three major class orientations. This conclusion is drawn with an understanding that the possibilities of an upward and downward mobility are inseparable. In the Malawi scenario, social mobility can best be described as intergenerational. ${ }^{1}$ The children occupy levels of positions their parents did not occupy or dreamed of. This is largely due to education and the democratic process in the political arena. These developments are making class distinctions less rigid. People are motivated and challenged to work hard.

Malawians are divided into lower, middle, and upper classes. The lower class is probably composed of the small-scale peasant farmers, the non-employed, the unskilled and semi-skilled employees. The middle class is made up of artisans, professionals in general, and the technicians on the lower end. The highly educated, probably with graduate degrees, the top-notch skilled technicians and professionals, the seasoned and successful politicians, plus the paramount chiefs (Inkosi ya Makosi) comprise the upper class. Chiefs and their families enjoy higher status although economically they may not differ with their subjects. Business persons may be found in all these categories, depending on the size, nature, and geographical location of the business activity.

There is a close relationship between class orientation and discipleship. It is easier for members of one class to reach and disciple a class below them than vice-versa. Same class orientation discipleship is even more effective. People mix freely because of

'Allan C. Kerckhoff, Socialization and Social Class (Englewood Cliffs, NJ: Prentice-Hall, Inc., 1972), 7-8. 
their common social character. However, this does not mean that it is impossible for persons in a lower class to effectively disciple the class above them. The life of the disciple has a lot to be desired by any person. This means that anybody can disciple regardless of class orientation but the most ideal is to match people accordingly.

\section{Discipleship and Gender}

An anthropological study of a black urban church in South Africa discovered that, although female members were in the majority, they could not hold certain offices not for lack of ability nor spirituality, but simply on account of their gender. ${ }^{1}$ The gender bias has its roots in traditional social structures. This has forced some women to aspire to new roles in the society. Louise Spindler laments, "Adaptation to the modern world has robbed women of significant roles, separated them further from the public domain, and even from their mates, and reduced their overall significance and influence."2 The church has not been any different.

Women have a greater role to play in the church. They are usually associated more with "sharing and caring." Mothers can influence several future generations. In addition, the older women of the church have a teaching ministry of the younger women as regards their conduct in the home and to the outside world (Titus 2:3-5). They can disciple by word and example. Older women can mentor new female converts.

${ }^{1}$ A. G. Schutte, "Dual Religious Orientation in an Urban African Church," African Studies 33 (1974): 114.

${ }^{2}$ Louise S. Spindler, Culture Change and Modernization: Mini-models and Case Studies (Prospect Heights, IL: Waveland Press, Inc., 1984), 111.

${ }^{3}$ James R. Ozinga, The Recurring Dream of Equality: Communal Sharing and Communism throughout History (Lanham, MD: University Press of America, 1996), 2. 
However, women cannot safely disciple men. It would be difficult because culture and social ethics would work against women. This is also true about men. They face the same difficulty to disciple women. The solution is to stay with same gender or couples where applicable. It would prevent barriers between different genders.

\section{The Challenge of Reaching the High Class}

Christianity in Malawi seems to be largely associated with people in the middle and lower classes. Church plans and initiatives have usually ignored the needs of the upper class. This is more by default than by design. The nature of church programs, like public evangelism conducted on open fields and the quality of the Adventist schools in Malawi cannot attract the modern higher class of the society. There is need to reach all classes of the society. The higher class will have a fair representation of all the races.

Christ's disciples came from all classes of people. He attracted the common fishermen as well as the highly placed in the public services like Matthew (Matt 9:9-13; Mark 2:13-17; Luke 5:27-32). The church leadership needs to intentionally include the cream of Malawi society in all church endeavors. The solution lies in targeted discipleship of those members like the chief justice, the accomplished attorneys, the seasoned politicians, the university professors, the medical doctors, and the chief executives in all sectors of the society. These have the capability to reach the upper class and turn Malawi upside down for the gospel.

Discipleship is pro-active. The church is a movement that makes disciples of all genders. The Bible teaches equality of all people (Acts 10:34-35; Gal 3:26-29). It is encouraging because even "the humblest and poorest of the disciples of Jesus can be a 
blessing to others." The church in Malawi has an obligation to resolve gender conflicts biblically and with urgency. In general, women have been very active and more effective in their various ministries. Women groups like the Dorcas Society have proved to be a power to reckon. There are many successful female evangelists in the literature ministry. These women can make a great contribution in disciple-making. They need to be engaged in all other ministries of the church according to their spiritual gifts.

\section{Bridges to Achievement Discipleship}

Recognition of people's achievements is one practice the church in Malawi has not seriously thought about. Yet, it has a motivational effect. Graduation rituals would attract people and at the same time serve as commitment forums for disciple-making.

Graduation Ritual Bridge: The church can perform this ritual for the children as they move from one age group activity to another. It can also be done for adults in recognition of significant achievements at work, distinguished community achievements, church seminar attendance, or welcoming new members joining the church congregation. A full Spirit-filled ritual with reading, a litany of commitment, and prayer of dedication could deepen the experience. For membership transfers, this means doing more than just reading and voting them in and out.

The Holy Spirit can use these simple revolutionary acts for winning souls and making them mature Christian disciples who will in turn help reproduce others.

${ }^{1}$ White, Steps to Christ, 83. 


\section{Rites of Passage}

Rituals provide a forum for orientation in African basic human values of a particular society or community. "From simple greetings to formal state occasions, rituals are regularized ceremonies of life that provide 'places' of security and are embedded in every culture." Rightly studied, the rites of passage can be a powerful tool in disciple-making.

There are times when church leaders make the mistake of quickly condemning rituals that do not really violate scriptural mandate but their own cultural values. ${ }^{2}$ These hasty decisions hinder the spread of the very gospel they zealously guard. The Catholic Church discovered this when they prohibited and even snatched their boys and girls from puberty and circumcision rituals among the Lomwe people of Mulanje, Malawi. ${ }^{3}$ The community regards these rituals as sacred. They are "a spiritual journey to adult-hood."4 The church leaders lacked the shrewdness of a snake and the innocence of a dove (Matt 10:16).

African rituals are community-oriented. ${ }^{5}$ Some of the rituals are confined to a particular local community. The rituals provide the initiates with a common bond in the

'Michael Pocock, Gailyn Van Rheenen, and Douglas McConnell, The Changing Face of World Missions: Engaging Contemporary Issues and Trends (Grand Rapids, MI: Baker Academic, 2005), 339.

${ }^{2}$ Ibid., 343.

${ }^{3}$ Stanlaus C. Muyebe, The Catholic Missionaries Within and Beyond the Politics of Exclusivity in Colonial Malawi, 1901-1945 (Lewiston, NY: The Edwin Mellen Press, 1999), 160.

${ }^{4}$ Ibid.

${ }^{5}$ Thorpe, 120. 
shared values and beliefs of the community's understanding of personhood. ${ }^{1}$ They convey a powerful message of the real world that "all life is transition with rhythmic periods of quiescence and heightened activity." In this regard, the rites enabled the elders to impart to their young people "a philosophy of life, death and renewal."3 This meant a rigorous discipline designed to bring out the best of the neophytes according to their worldview.

Certain transitions did not require defined rituals. When boys and girls respectively moved from their parents bedrooms to their grandmothers' kitchen or with others of their gender and age group, it was done quietly without any ceremony. This was also true when young boys around age five or six were promoted to eat with their fathers. It did not require a laborious ritual ceremony. They joined their fathers to eat with others at the village courtyard ( $p a$ bwalo). This was a place of socialization, skill development, a factory for crafts, and a place where men of experience informally advised the young boys about life in general. It was a meeting place for men of the village.

\section{Phases of Rituals}

Birth, puberty, circumcision, marriage, pregnancy, and death are some of the rites of passage that were accompanied by certain rituals. There is a general agreement among anthropologists that rites of passage fall into three major phases. Van Gennep classified

${ }^{1}$ A. H. Mathias Zahniser, Symbol and Ceremony: Making Disciples Across Cultures (Monrovia, CA: MARC, 1997), 96.

${ }^{2}$ Arnold van Gennep, The Rites of Passage, trans. Monika B. Vizedom and Gabrielle L. Caffee (Chicago, IL: The University of Chicago Press, 1960), ix.

${ }^{3}$ Henrietta L. Moore, Todd Sanders, and Bwire Kaare, Those Who Play with Fire: Gender, Fertility and Transformation in East and Southern Africa (London, Great Britain: The Athlone Press, 1999), 84-85. 
them as separation, transition, and incorporation. ${ }^{1}$ Zahniser calls the second phase "liminality," a Latin word for "threshold" because it is transitional.

During the separation phase, the individual initiate ceases to be a member of the old status while not yet in the next. It is like being stripped of your status. The individual undergoes a radical change psychologically, emotionally, and even physically. ${ }^{2}$ The transitional phase is analogous to spiritual transformation. Depending on the rite of passage, the person may be subjected to isolation, silence, diet restrictions, dress code, trials and other forms of ordeals by the instructors. ${ }^{3}$ Like the Holy Spirit, the instructors step in to carry out their work. "Transforming real children into real adults for themselves, for their parents, and for their community requires a temporary suspension of social structure."4

Successful completion of trials during transition phase may be recognized by a new status, new name, a title, and in some cases by receiving a diploma or a driver's license. ${ }^{5}$ Incorporation brings new possibilities, challenges, and a new identity. Rites are in a way guardians of culture. The rites are meant to produce "competent people to fill significant social positions." accountable to the society in all their actions.

${ }^{1}$ Ibid., vii.

${ }^{2}$ Kenneth Tollefson, "Maintaining Quality Control in Christian Missions," Missiology: An International Review XVIII (July 1990): 316.

${ }^{3}$ Zahniser, 94.

${ }^{4}$ Ibid., 93.

${ }^{5}$ Pocock, Van Rheenen, and McConnell, 340.

${ }^{5}$ Tollefson, 326 . 
African rites of passage are characterized by rich symbolism. Shaving of the head is one such powerful African symbol with multi-purposes. It was common and connected with rituals of birth, initiations, and funerals. It symbolizes purification. It points to an end of the old and entry into a new stage of life-cycle. Shaving the head transmitted the message that life was not the same. This deepened the experience of the individuals.

Rites of passage can be compared with the disciple-making process in that the initiates are thoroughly trained. The education sets them on the path of growth, maturity, and leadership in their respective communities. The loss of identity during a ritual is similar to a convert before baptism. One abandons the old life which in some cases includes former faith. In the end, a ritual and disciple-making produce a transformed product ready to take on new responsibilities.

The one difference between rites of passage and disciple-making process is the freedom to choose. Unlike discipleship, there are incidents where the initiates are taken by force.

\section{Rites of Puberty Passage (Chinamwali)}

Puberty ritual (chinamwali) is a critical female initiation throughout Malawi. Every girl looks forward to this time with anticipation and anxiety. Chinamwali ritual marks the first menstruation experience of a young girl. It is a transition from childhood to adulthood. Chinamwali was a major female ritual. Traditionally, there was a period of isolation. Unlike the practice in southeastern Alaska where the pubescent (namwali) took 
months in isolation, ${ }^{1}$ Malawian girls took anywhere between two and four weeks. ${ }^{2}$ Previously, many girls dropped out of school when they reached puberty. They were assumed to be ready for marriage. Girls education was not popular then. Several factors have changed this attitude. Today, puberty is attained at a very young age and school has no age limit or gender preference.

The day of release marked a climax of the whole ritual. The older women shaved the pubescent's head and gave her a supervised bath in the stream. After a bath, she wore new clothes. Among the Phoka people of Livingstonia, north of Malawi, nankungwi took away the old clothes and any utensils the pubescent used during the isolation period. ${ }^{3}$ She never saw them again. These items were associated with the old life which was symbolically washed away during the bath ritual. It was a total divorce from the old life.

The candidate was guided by an assistant (phungu) who had already gone through the ritual. Phungu was usually her best friend in the village or first cousin, her aunt's daughter. The selection of phungu was based on a thriving relationship with the pubescent. It could be said to have been natural because of the existing relationship. The chief nankungwi counseled the pubescent to put away the old child-like behavior and start to dress and behave in a respected manner befitting an African woman. There was commendation and condemnation of certain characteristics of the pubescent. The counsel was partly pre-marital in nature. In fact, Van Gennep looks at

${ }^{1}$ Ibid., 318.

${ }^{2}$ Rosemary Masoka, a Malawian, interview by author, February 8, 2006, Berrien Springs, MI.

${ }^{3}$ Ibid. 
Any discussions following a violation of the gag rule are held at dambwe. Sindima shared an incident that took place during one of his visits to Malawi. The Nyau members had a case with one of their own and refused to discuss it at the village court. Although Nyau membership is strictly for males, they asked the village head-woman, the arbitrator to go to dambwe at the graveyard and hear the case. She went and settled the case at dambwe. ${ }^{1}$ The society maintains a high standard of discipline.

The neophytes sleep out in booths and are subjected to hardships during the initiation. This prepares them for adversity. Their target is to "recreate," as it were, a total new person for the community. During their stay at dambwe, they learn what umunthu (being a human being) means in their society. Their philosophy is that education, wealth, or status do not make an individual into a person. To be a person, the individual must measure up to the standard of the society. A strong moral society needs virtues that include "truthfulness, generosity, self-respect, and respect for others, integrity, duty, and responsibility." The young members of the society are given intensive instructions in these areas.

Sindima continues and in his capture of the concept of umunthu, he stresses the fact that physical appearance does not make a person, a person. It is the quality of character, possession of basic human virtues that people refer to when they say, "Uyu ndi munthu" "This is a person." The Nyau society is deemed to have the ability and 2006.

${ }^{1}$ Harvey Sindima, Colgate University, NY, telephone interview, February 9,

${ }^{2}$ Sindima, Africa's Agenda: The Legacy of Liberalism and Colonialism in the Crisis of African Values (Westport, CT: Greenwood Press, 1995), 202.

${ }^{1}$ Ibid., 203. 
reputation to provide this high standard of discipline. They were strong in traditions. For the missionaries, they were a hindrance to Christianity. "There are indications that in some degree Nyau is a counterblast to the influence of the missionaries, and an attempt to keep alive the traditions of the tribe and respect for its leaders."1

Both chinamwali and Nyau rites of passage were critical points for the Malawian communities to fulfill their task of molding, building, and imparting their core values to the youngsters. Once initiations were carried out, the initiates had a different worldview. The society felt justified to hold the initiates to the highest standard of their community. It therefore became the duty and responsibility of the initiates to live that re-oriented life. In the Nyau tradition, the members are always in contact with one another. They continue to meet for mask-making and traditional dance practices. This gives them an opportunity for advanced sessions which help to deepen their commitment and at the - same time prepare future instructors. ${ }^{2}$ These activities are intensified during dry months, from around May to October. There are no exceptions or short cuts in the rituals.

\section{Bridges to Discipleship}

If there had been a critical contextualization of the message when it was originally introduced, some cultural practices of the people could have been employed as bridges to the Christian faith and its practices. People's cultural felt needs especially in the area of rituals would have been adequately met. The rituals could have served as vehicles of communication to deepen people's faith and experience in Christianity.

${ }^{1}$ Debenham, 87.

${ }^{2}$ Nkhata, February 13, 2006. 
The rites that require separation, transition, and incorporation have lots of similarities with Christian rituals beginning with conversion itself. Baptismal preparatory classes and the actual baptism open doors to church membership. The individual freely participates in other Christian rituals like communion service. This is also true in the Malawian social context where after isolation and intense counseling, the person receives change in status and is incorporated into the society.

Despite the possibility of hidden unchristian elements in some of the rituals, the fact remains that tradition has faithfully kept these age-long indigenous cultures to this day. One wonders how they have done it. Christianity and other religions, civil powers in Australia, America, Canada, including the "colonial authorities throughout Asia, Africa, and South America" have failed to stamp them out. ${ }^{1}$ Discipleship could borrow from the administrators of these rites and be assured of success and continuity.

The traditional discipling model is impressive in several ways. In the first place, the target group is caught at the right age in the life-cycle. The instructors and the community work together to achieve their common goal to have every person initiated to instill the basic values and beliefs of the local society. Surprisingly, even those who are snatched into the ritual against their will come back happy that they went. Others like the members of Nyau secret society respond boldly when need arises for their service.

To achieve their goal, the candidates are isolated, taken away from distractions and are able to meditate on their anticipated status. While in the camp, the neophytes have no status. Their only hope is to endure the intensity of the ritual and move to new

${ }^{1}$ Ken S. Coates, A Global History of Indigenous Peoples: Struggle and Survival (Houndmilla, Great Britain: Palgrave MacMillan, 2004), 191-192. 
and higher status. The instructors take special interest in the initiates to make friends with the youngsters and assume parental roles over them. The whole community is pervaded by the air of celebration and anticipation of their release.

The change of status is a motivational factor worth investment of time and effort to achieve the community's ideal personhood, umunthu. The initiates are adherent disciples and guardians of the beliefs and values of the community. To be counted as mature people and backbone of the society was a great honor. The outgoing generation of elders find their peace and satisfaction when they know that the society is safe in the hands of people with umunthu. Both parties were equally motivated.

Nyau and chinamwali rituals provide a bridge from tradition to Christianity that seeks to instill values of the kingdom. The two traditional discipling models employ intensified training methods during the transition and enjoy community support.

Like soldiers, the disciples are expected to endure hardships and to pass on to others what they have learned ( 2 Tim 2:2-3). Nyau rituals have survived because they were passed to next generations. The members are well disciplined to settle their differences at dambwe. The Christian disciples are admonished to follow biblical counsel (Matt 18) and settle their disputes within the church (1 Cor 6:1-4).

Discipleship strategy could adopt the concept of nankungwi/phungu as mentor models for every new disciple. The church can introduce an alternative Christian ritual of name-change at baptism as practiced by the Catholics in Malawi. It would deepen the person's conversion and baptism experience. The new name would be a reminder of the happiest and solemn occasion, and the responsibility that comes with the new status. 


\section{Summary}

The anthropological reflections show that Malawians are among the Bantu branches. They had rites of passage as part of their culture which were characterized by rituals. The Malawian rituals have some similarities with Christian experiences. They could be bridges from ATR to Christianity. The rites can be used to a great advantage to advance the Gospel Commission to make disciples of all nations.

Missiologically, Malawians were already people of faith in traditional beliefs which was a providential preparation for the coming of Christianity. The people did not only accept Christianity, but played an active role in its spread within and beyond their borders. This spirit has continued and shows itself in both traditional and African indigenous churches. However, there is need for emphasis on disciple-making ministries. A careful selection of theologically sound beliefs compatible with church practice could enhance biblical disciple-making strategy in Malawi. The process will also address the quest for African authentic Christianity.

The development of service-oriented Christian disciples calls for education of the whole church. In the context of the Great Commission, apostle Peter urges the church living at the end of the time, to use every gift for service and salvation of others. "The end of all things is near. Therefore be clear minded and self-controlled so that you can pray. Above all, love each other deeply, because love covers over a multitude of sins. Offer hospitality to one another without grumbling. Each one should use whatever gift he has received to serve others, faithfully administering God's grace in its various forms" (1 Pet 4:7-10). Disciple-making needs to use every possible means to multiply the number of active Christian disciples for deployment in the Gospel Commission. 


\section{CHAPTER 4}

\section{DISCIPLE-MAKING STRATEGY}

\section{Introduction}

Learning is the main initial activity of disciple-making strategy. However, gaining knowledge is not complete in itself until it becomes a service tool in fulfilling the Great Commission. Good disciple-making strategy includes not only teaching but being a role model and a mentor to the learner. This makes Christian discipling different from secular career mentors because the learning process includes a demonstration of a consistent exemplary Christian life.

It is more rewarding for the disciples to start working with someone while in the training. ${ }^{1}$ In this way, a learner gets to test the classroom theories right away. Experience shows that this is the best method of preparing disciples in a most practical manner. A

${ }^{1}$ In 1982, the writer conducted a series of evangelistic meetings at Lizulu, his pastorate district. The baptismal candidates remained at the end of every meeting to go over the topic and have their questions answered. The researcher also used the time to teach the basics in witnessing. The candidates were encouraged to put into practice whatever they learned every evening. The following day they reported their experiences. This generated great interest among the baptismal candidates. They witnessed to their friends and brought them to the meetings. It was the best on the job training they received. The first baptism was for those who had been studying in the baptismal class prior to the meetings. This group was already discipling others. At the second baptism, the newly baptized were invited to stand by the baptistry and greet their friends as they came out of the water. There was visible joy and celebration. The discipleship continued. This is the best way to train and show the members their Christian obligation in the Gospel Commission. 
suitable responsibility strengthens a new convert. ${ }^{1}$ It is incumbent on the disciple-making pastors to make sure that "just as soon as a church is organized, let the minister set the members at work. They will need to be taught how to labor successfully. Let the minister devote more of his time to educating than preaching. Let him teach the people how to give to others the knowledge they have received."2

The process of making disciples involves more than a theory. In Christ's estimation, "words and works were to revolutionalize the world." A consistent Christian lifestyle backed by personal habits of Bible study and prayer reflects an intimate relationship with Christ. The knowledge of Jesus becomes a sacred responsibility as it is meant to be shared with others. In fact, real maturity of a Christian disciple is shown by leading others to Jesus, the true light of the world (John 1:9). Surprisingly, the knowledge of Christ increases with sharing.

The church needs to create and offer opportunities for ministry within the body and in the community. The ministries serve as structures for individual and corporate rapid growth in the church. "A working church is a growing church. The members find a stimulus and a tonic in helping others. ${ }^{, 4}$ Pastors and their leadership teams have a duty to initiate various ministries so that everybody is engaged in the Gospel Commission in which the church finds its mission in the communities of the world.

${ }^{1}$ Donald Anderson McGavran, Church Growth and Christian Mission (New York, NY: Harper \& Row Publishers, 1965), 205.

${ }^{2}$ Ellen G. White, Testimonies for the Church, 9 vols. (Boise, ID: Pacific Press Publishing Association, 1948), 7:20.

${ }^{3}$ White, Fundamentals of Christian Education, 47.

${ }^{4}$ White, Gospel Workers, 198. 
It is important to have regular periodic evaluation of the progress, the felt needs, and the impact of these ministries. Evaluation is a tool to prevent sidetracking. It helps to keep in focus the whole purpose of the ministries. It checks out growth obstacles. Further, it deters the possible development of a ministry that has no direct relationship with the church. Taylor McConnell suggests creation of a "Council on Ministries or some similar body to coordinate the total planning and programming for the entire church." The local churches in Malawi have evangelism councils. For the sake of emphasis, it can be called a discipleship council. This council can co-ordinate all the discipleship activities including the various ministries of the church and carry out an evaluation process to determine the effectiveness and relevancy of the ministries.

\section{Education of Established Church Members}

Teaching is a traditional pastoral function. Both the Old and New Testaments testify to this fact. One of the duties for the priests was to read and explain the Scriptures for the people (Neh 8:7-8; Ezek 44:23). For example, Ezra was a highly learned priest and a teacher. He devoted himself to know and to teach the law of God (Ezra 7:10-11). Ezra was known as "a teacher of the Law of the God of heaven" (Ezra 7:21). He appointed and taught the magistrates and the judges who did not know the law (Ezra $7: 25)$.

Nehemiah and the Levites were instructors of the people (Neh 8:9). The Israelites sought knowledge from the priests (Mal 2:7). The pastors owe this priestly function to

\footnotetext{
'Taylor McConnell, The Pastor As Educator (Nashville, TN: Local Church Education, Board of Discipleship of the United Methodist Church, 1972), 1.
} 
their members. Discipleship provides the context for continuation of teaching ministry.

In the New Testament, Jesus was a recognized Rabbi, a teacher from God (John 3:2). He taught with authority (Matt 7:29). His disciples were committed teachers and could not stop teaching in spite of strict orders forbidding them (Acts 5:28, 42). In terms of human contribution, the success of SDA missions in Malawi is owed to the teaching ministry strategy.

Howard Rice observes that teaching is one spiritual gift found in everyone of Paul's lists. ${ }^{1}$ Apostle Paul advised that one qualification for a church leader was ability to teach (1 Tim 3:2). Education of the church members deserves to be a priority for the pastor. It needs to be revived in a quest to revitalize the church for continued discipling of all the members. In his research on adult education, Russell Hutchison concluded that the education of adult members increases church attendance during worship. ${ }^{2}$ It contributes to spiritual growth of the disciples.

There are several things to consider in regards to the education of the adult members. Probably, the very first thing is for every pastor who is the principal educator to know that self-esteem is "a pre-requisite to adult learning." One way to achieve this is for the instructor to point out and appreciate the past activities done by the old members. The members would feel happier if their leaders recognized and appreciate their services

'Howard Rice, The Pastor as Spiritual Guide (Nashville, TN: Upper Room Books, 1998), 107.

${ }^{2}$ Russell S. Hutchison, "A Study of the Christian Education of Adults in Relation to the Needs and Values of Adults in Selected Protestant Churches in Muskingum County, Ohio" (Ph.D. diss., University of Pittsburgh, 1962), 170.

${ }^{3}$ Marion Terry, "Making a Difference in Learners' Lives: Results of a Study Based on Adult Literacy Programs," Adult Basic Education: An Interdisciplinary Journal for Adult Literacy Educators 16, no. 1 (Spring 2006): 9. 
in public. This would even motivate them to do more. This boosts their self-esteem and gives them confidence to tackle present and future challenges.

The adult church members in Malawi still remember different soul winning training programs in the 1960s and 1970s. The lay persons were taught basic skills for conducting evangelistic meetings. They were stirred by the theme song, Mbuye Yatsani Moto Wa Otayika, a translation from the English version "Lord, Kindle a Flame in My Heart for the Lost." This was a time of big growth in the whole union and the division. Phaize Salhany, who was the Union Secretary for the Home Missionary Department summarized the MU strategy when asked during division meetings: "Believing better trained members make better workers for God, this Union plans a Lay Preachers' school in every district during 1965 with special emphasis on making every member an example of 'Christianity in Action."”2 Every department of the church in Malawi was involved in this evangelistic thrust. All the departments in the local churches were also required to hold evangelistic meetings after receiving training.

Salhany went further to say that baptismal class members were required to have and bring to class every Sabbath, "a Bible and a catechism."3 The baptismal manual articulates the doctrines and Christian theology. In fact, Maylanne Maybee says the goal for adult training is to "equip people to understand the 'essence' of their ministry, to

${ }^{1}$ Many old church members still remember these meetings and the sermons prepared by Alvin E. Cook, Ministerial Secretary of the then Trans-Africa Division (TAD) in his book "Preach the Word."

${ }^{2}$ Phaize Salhany, "Each Alive to Win One in 'Sixty-five'," Trans-Africa Division Outlook, December 15, 1964, 8.

${ }^{3}$ Salhany, "Ninety-Three Baptized in Malawi," Trans-Africa Division Outlook, May15, 1967, 2. 
interpret scriptural and theological underpinnings of ministry, and to be proficient and competent in recreating, not just replicating, what they've experienced."1 Lay persons need training in basic rudiments during their empowerment for the Great Commission. Unfortunately, as already pointed out in this project, the promotions of these programs were confined to a period of time. They had a limited term of life. There is one major difference with this proposed discipleship education. It is planned to be an ongoing ministry of the churches.

Another consideration is the learning ability of the adult members. Their formal education differs widely. Some are faced with literacy challenge but they desire to be involved in the mission of the church. The instructor needs patience to move at their pace. As for Jesus' teaching style, one sees that each approach was colored with "flexibility and intense attention to individual persons."2 No persons should be given an idea that they are slowing other people. One way to solve this dilemma is to divide the people into smaller classes. The teacher can, as far as it is possible, group them according to their academic levels. This will make them free to ask questions and participate in all the discussions. In addition, it is an effective method of teaching and motivating the adult-church members. This too has to be done with all caution to avoid offending some members.

The scriptural-based discipleship strategy presents its strong appeal to the laity who need to sense their God-given responsibility in the body of Christ. The "challenge is

'Maylanne Maybee, ed., All Who Minister: New Ways of Serving God's People (Toronto, Ontario: ABC Publishing, 2001), 52.

${ }^{2}$ Gangel and Wilhoit, 14. 
to help learners integrate ministry in church and daily life, including work and school, family and community, and volunteer and paid service." Pastors have a duty to present this appeal to the laity and cannot relegate this important teaching ministry to some obscure position among their duties. The church stands in great need of education for the purpose of making disciples of all nations.

\section{Modeling for the New Converts}

The new converts observe what the old members do. The old members become a standard for the new members. The church members may witness positively or negatively. Paul compares converts to Christ's open letters 'known and read by everybody" ( 2 Cor 3:2). The messenger's life and deeds have an influence on the unbelievers (Matt 5:16). "Our lives should be attractive to those around us, offering a real option. Our entire value system, that is our morality and philosophy of life, should agree with the Scriptures."2 The Holy Spirit works in and through the human instruments to bring Christ to the people of all ethnic backgrounds.

The baptismal class can be a workshop for thorough preparation of the new disciples. Great care is to be given in the selection of an elder who teaches this class. The teacher can exert lasting impressions on the new members. It is important to select an experienced person with ability to teach and one who carries a real burden for souls. The baptismal class teacher lays a foundation for the new members. I am always grateful

${ }^{1}$ Maybee, 53.

${ }^{2}$ Jim Petersen, Evangelism As a Lifestyle (Colorado Springs, CO: NavPress, 1980), 138-139, quoted in Andy \& Kim Harrison, Seek, Share, Serve (Nashville, TN: LifewayPress, 2002), 212. 
to the church elder who taught me in the baptismal class. He knew the Bible and manifested Christ-like spirit. He was an exemplary person in that church.

Some important lessons in the baptismal manual are not adequately covered. Discipleship is one of them. In such cases, the teacher has the responsibility to make sure that these lessons are covered adequately. Teachers can be creative and try some innovative methods to educate the new generation of church members. This is not a proposal for change of the doctrines. It is a trial of various methods. It does not interfere with biblical principles and cardinal beliefs of the church.

The churches may consider open days and orientation of new members, the practice common in most of the educational institutions. Earl Waldrup suggests that during this time"the new member must be led to the deepest possible commitment to the biblical concept of church membership." Those members who join the church by transfer or by profession of faith can be included in this orientation. ${ }^{2}$ In this way, they will be initiated into a particular lifestyle of their chosen church.

The education of the adult church members creates awareness about the urgency of making disciples. When the new converts discover that the old members are actively involved in disciple-making, they too become participants early in their Christian life. They grow with that spirit that characterizes the whole church. The trained adult members can be paired with the new members in a mentor-disciple relationship. The new converts who go through this process, attains real practical growth to spiritual maturity.

${ }^{1}$ Earl Waldrup, New Church Member Orientation Manual, rev. ed. (Nashville, TN: Convention Press, 1970), 7.

${ }^{2}$ Ibid., 4-5. 
Healthy churches continue to make disciples out of their adult members while at the same time endeavoring to disciple every new member.

According to Scott Morton, discipling is a cycle composed of four stages:

reaching, discipling, equipping, and sending. ${ }^{1}$ The disciple-making strategy is a holistic cycle. It has a caring attitude of a shepherd.

New members lack experience on how to reach and lead a person to Christ. Part of the modeling is to demonstrate for them. It means to take them out for a real encounter with people on the street or in the home. The experience helps to take away shyness or fear. It also inspires them. "Let the teachers lead the way in working among the people, and others, uniting with them, will learn from their example. One example is worth more than many precepts."

Discipling education ought to be practical so that it also meets human needs of individuals and the large community. Morton suggests that during the equipping phase, new members can be taught how to handle personal issues like stress management, conducting an in-depth Bible study, spiritual gifts, and leadership of small groups. ${ }^{3}$ Ellen White carries it further with helpful additional detailed counsel. "Every church should be a training school for Christian workers. Its members should be taught how to give Bible readings, how to conduct and teach Sabbath School classes, how best to help the poor and to care for the sick, how to work for the unconverted. There should be schools of health, cooking schools, and classes in various lines of Christian help work. There should not

\footnotetext{
${ }^{1}$ Scott Morton, Down to Earth Discipling: Essential Principles to Guide Your Personal Ministry (Colorado Springs, CO: NavPress, 2003), 25.

${ }^{2}$ White, Ministry of Healing, 149.

${ }^{3}$ Morton, 25.
} 
only be teaching, but actual work under experienced instructors."

\section{Bible Study}

The postmodern generation rejects the idea of absolute universal truth. It advocates relativism. This undermines faith in the Bible. David compared God's Word to a "lamp" to his feet and a "light" in his path (Pss 119:105). Through the study of the Bible, the Holy Spirit guides the reader into all truth (John 16:13). Paul's counsel is to study the Scriptures so that one "correctly handles the word of truth" (2 Tim 2:15). The disciples should be able to defend their faith and basis of their hope (1 Pet 3:15).

There are several benefits accrued from the study of the Bible. They range from intellectual power to the development of spiritual nature. ${ }^{2}$ However, the Bible's "grand object in view is to reveal God to man so as to draw man into vital and loving relation with God." ${ }^{3}$ The study of the Bible helps to cultivate a closer relationship with God and to obtain "a clear knowledge of His will."4 The old members and the new converts need to know Jesus personally and the plan of salvation. This is not a superficial knowledge. It means "to learn the full meaning of the words of truth, and to drink deep of the spirit of the Holy Oracles." This kind of Bible study calls for a careful search of the Scriptures. It demands discipline and surrender of the will and thoughts to God.

${ }^{1}$ White, The Ministry of Healing, 149.

${ }^{2}$ White, Education, 124.

${ }^{3}$ Arthur T. Pierson, The Bible and Spiritual Life (New York, NY: Gospel Publishing House, 1908), 13.

${ }^{4}$ White, The Great Controversy, 69.

${ }^{5}$ White, Our High Calling (Washington, DC: Review and Herald, 1961), 205. 
Individuals choose their time and style of study. Some prefer reading systematically. Others like to read the books or passages at random. There is no one way or time to study the Bible. The whole purpose of setting aside some time is to have an encounter with the Person of the Scriptures, Jesus Christ (John 5:39). "The student should learn to view the word as a whole, and to see the relation of its parts." Time spent in the study of God's Word is always a gain to the individual.

The instructor of these Bible studies can go deeper over the topics already covered during preaching from the pulpit. "This was the method that Christ taught His disciples. When the great throngs gathered about the Saviour, He would give instruction to the disciples and the multitude. Then after the discourse the disciples would mingle with the people and repeat to them what Christ had said. Often the hearers had misapplied Christ's words, and the disciples would tell them what the Scriptures said and what Christ had taught that they said." In this way, Jesus was able to correct the people and they appreciated the truth more. They became intelligent believers. Their faith was firmly grounded in God's Word.

A conversational Bible study is more effective because it gives the student the maximum benefit. ${ }^{3}$ This approach makes allowances for questions and answers. New believers tend to have questions they need answers for. After getting biblical explanations and answers, they decide to obey God on the basis of His Word.

${ }^{1}$ White, Education, 190.

${ }^{2}$ Ellen G. White, Testimonies for the Church, vol. 6 (Boise, ID: Pacific Press Publishing Association, 1948), 88.

${ }^{3}$ White, Voice in Speech and Song (Boise, ID: Pacific Press Publishing Association, 1988), 234. 
Victory over the devil's temptation is another reason for this deeper study. Christ met the devil with Scripture (Matt 4:4-10). Bible study gives knowledge and power to resist Satan's attacks. ${ }^{1}$ Whenever the devil comes with a temptation, the Holy Spirit reminds the tempted disciple about God's power and promise to protect (John 14:26). But, God's Spirit can only remind individuals what they studied and hid in their heart or mind (Pss 119:11). It is important for the new disciple to stay in touch with God through the study of His Word.

Those who endeavor to obey all the commandments of God will be opposed and derided. They can stand only in God. In order to endure the trial before them, they must understand the will of God as revealed in His word; they can honor Him only as they have a right conception of His character, government, and purposes, and act in accordance with them. None but those who have fortified the mind with the truths of the Bible will stand through the last great conflict. To every soul will come the searching test: Shall I obey God rather than men? The decisive hour is even now at hand. Are our feet planted on the rock of God's immutable word? Are we prepared to stand firm in defense of the commandments of God and the faith of Jesus? ${ }^{2}$

Personal study of God's Word energizes the spiritual life of the disciples. It prepares them for the present and the eschatological battles of the devil. The disciple makers face trials and discouragements as tests of their faith which grows even stronger. Bible study enables the disciples to intelligently defend their faith in God.

\section{Prayer Life}

Jesus took time to be alone with God in prayer (Mark 1:35; Matt 26:26). Luke goes further to say that "Jesus often withdrew to lonely places and prayed" (Luke 5:16). He was a prayer warrior. He prayed for Himself, His disciples, and for all the believers

\footnotetext{
${ }^{1}$ White, The Great Controversy, 51.

${ }^{2}$ Ibid., 593-594.
} 
(John 17). The disciples were touched by Jesus' prayer habits. No wonder they asked Him to teach them how to pray as John the Baptist had taught His disciples (Luke 11:1). Christ is the model for praying disciples. As already mentioned, God uses Scripture to communicate His will to His children. But, effective communication is two-way. It is through prayer that the disciples communicate back to God, the Creator.

"Prayer is the opening of the heart to God as to a friend" says Ellen White. ${ }^{1}$ Prayer deepens the relationship with God. It is not so much of a posture, but an attitude of the disciples to depend on God. ${ }^{2}$ It is a powerful spiritual weapon in the hand of Christ's disciples. Prayer opens prison houses and frees God's innocent disciples (Acts $12: 1-19)$. It is the greatest force in disciple-making.

God hears prayers of His children anytime, anywhere, and in any circumstance (Pss 55:17). "Nothing is too great for Him to bear, for He holds up worlds, He rules over all the affairs of the universe. Nothing in any way that concerns our peace is too small for Him to notice." 3 God expects all His children to share their joys and sorrows with Him through prayer.

David wrote that all the people would come to their prayer-hearing Creator (Pss 62:2). God does not always answer prayers according to the deeds of the petitioner. Jesus granted requests for healing made by non-Jewish people like the Syrophoenician woman, the centurion, and the nine lepers (Mark 7:24-13; Matt 8:5-13; Luke 7:1-10; 17:11-19). These people displayed great faith in the Great Physician. In spite of these

\footnotetext{
${ }^{1}$ White, Steps to Christ, 93.

${ }^{2}$ Ibid., 100.

${ }^{3}$ Charlie Riggs, Learning to Walk With God (Minneapolis, MN: World Wide
} Publications, 1988), 103. 
examples, God expects faith and obedience to His revealed will.

There are conditions for the Lord to answer prayers. Unconfessed and unforsaken sin builds a big wall and hinders prayers (Isa 59:1-2). Those who approach God ought to search their hearts and make things right with Him (Pss 66:18; 139:23-24). Willing obedience is to characterize disciples' relationship with God (Prov 28:9). The other condition to be met is faith (Heb 11:6; Mark 11:24). "Prayer and faith are closely allied, and they need to be studied together. In the prayer of faith there is a divine science; it is a science that everyone who would make his lifework a success must understand."1

Both personal Bible study and prayer have a way of keeping the disciples' focus on Christ. The relationship of convenience with Christ is to be shunned by the disciples. "Seeking God is never just a one-time affair or a passing fancy." God loves His children with everlasting love (Jer 31:3).

Theoretical knowledge about prayer does not do anybody any good. Prayer is an activity "best experienced in its actual practice." with and for the new disciple. Answers to specific prayer requests will strengthen the beginner's faith. In cases where the new disciple does not know how to pray, the student may repeat after the teacher. There is nothing like a perfect prayer. It is not the eloquence. Sometimes a person with a heavy heart may not have the strength to utter a

${ }^{1}$ White, Education, 257.

${ }^{2}$ Klaus Issler, Wasting Time With God: A Christian Spirituality of Friendship With God (Downers Grove, IL: InterVarsity Press, 2001), 130.

${ }^{3}$ Andrew Purves and Charles Partee, Encountering God: Christian Faith in Turbulent Times (Louisville, KY: Westminster John Knox Press, 2000), 116. 
word just like Hannah (1 Sam 1:9-20). One aspect of the work of the Holy Spirit is to help in such cases (Rom 8:26). The Lord hears every prayer.

Prayer is an essential ingredient of growth in Christ. It teaches humility, patience, reliance on God, and perseverance. Besides praying for themselves, the disciples are also to remember God's work and workers, salvation of souls, the rulers, governments, weather, the sick and everyone (Matt 9:38; Col 4:3-4; 1 Tim 2:1-2; James 5:13-18). These are some of the unselfish prayers that reveal peoples' concern for others. This spirit reflects real spiritual growth with Christ.

Every prayer is to be made in Jesus' name. He has promised that God will grant the petitions made in Christ's name (John 14:13-14; 16:23). This is a conditional promise. Praying in His name "means that we are to accept His character, manifest His spirit, and work His works." Accepting Christ's character means to develop and manifest it. Having done this, ask God's will to be done.

The disciples who allow God to talk to them through the Bible and share their life with Him through prayer, will grow from strength to strength. They will be spiritual giants and God's friends. The devil fears such people. They have found a secret to a victorious life.

\section{Christian Lifestyle}

When one becomes a Christian, it means change of masters. The change is not automatic or easy. Some of the practices have been cherished from childhood. As such, they become a habit and are hard to overcome over a night. It would be commendable

${ }^{1}$ White, The Desire of Ages, 668. 
for the old members to exercise patience, kindness, and sympathy towards the young in faith. ${ }^{1}$ It takes time to completely overcome some of the bad habits learned before becoming Christians. At the same time, forsaking the old lifestyle is not enough. It leaves the person vulnerable to powerful evil spirits (Matt 12:43-45). If the individuals go back to the old life, they look at themselves as failures. They become discouraged and afraid to try again. In view of this possibility, there needs to be a strategy to prevent this from happening. The best way to overcome the old long-established habits is to develop good stronger habits. There is need for the individual to exercise the will and to co-operate with the Holy Spirit, who is the Agent of change.

After individuals accept Christ, the Holy Spirit seals them as "God's possession" (Eph 1:13-14). They are given power to be called God's children (John 1:12-13). The Holy Spirit starts working on their lives to transform them. This wind-like operation of the Spirit is an ongoing work of sanctification. Through the study of the Bible, the Holy Spirit shows the individuals what stuff in their lives to discard. The person desiring change must uphold the Bible not just as a good moral instruction book, but as "the word of the living God, the word that is our life, the word that is to mold our actions, our words, and our thoughts." ${ }^{.2}$ The Bible gives direction and guidance.

By now, the individuals are aware that their bodies are the temples of the Holy Spirit (1 Cor 6:19-20). As a Christian, there will be many areas requiring change. Some of these will be in health habits, dress, entertainment, and the whole way of life. It is a totally new beginning of a spiritual journey with Jesus, the new Master.

${ }^{1}$ White, Evangelism, 341.

${ }^{2}$ White, Education, 260. 
The question to consider is how to best develop the body, the mind, the social and the spiritual faculties. Making vital connections between faith and everyday life is one great challenge that still faces Christian spirituality today. ${ }^{1}$ Religion has to be meaningful and relevant to the daily life. However, there needs to be a difference with the world. There is no place for compromise of principles. "Christ's followers are to improve the moral tone of the world, under the influence of impartation of the Spirit of God. They are not to come down to the world's level, thinking that by doing this they will uplift it. In words, in dress, in spirit, in everything, there is to be a marked distinction between Christians and worldlings. The distinction has a convincing influence upon worldlings."2 The difference with the world ought to be maintained.

The Bible is the standard of every teaching and practice. Biblical principles which address these areas are to be upheld. This will further help the new members to attach more value and confidence in the Bible.

1. Dress. God had a dress code for the priests (Ezek 44:17-19). Every beginner disciple needs dress education in keeping with God's standard. As a principle, God requires His children to dress in keeping with their faith. Christian dress is simple, appropriate, and meets standards of morality (1 Tim 2:9). Extravagance, nose rings, tattoos, and any such things are not part of God's dress economy. God desires His children to develop the inward beauty which manifests itself in good deeds (1 Tim 2:10; 1 Pet 3:3). Conformity to world standards is to be avoided. Christian conformity is heaven-oriented.

${ }^{1}$ Barry L. Callen, Authentic Spirituality: Moving Beyond Mere Religion (Grand Rapids, MI: Baker Academic, 2001), 207.

${ }^{2}$ Ellen G. White, That I May Know Him (Washington, DC: Review and Herald, 1964), 305. 
2. Health Habits. Health is a gift from God. He wants His children to enjoy good health (3 John 2). Introduce the new converts to an Adventist health lifestyle. It means going back to creation for an original diet of vegetables, nuts, grains, and fruits (Gen 1:29). Flesh was introduced after the flood, but with restrictions. There are clean and unclean animals (Lev 11; Deut 14). God placed restrictions even on the clean animals. The people were to abstain from eating blood and fat (Gen 9:4; Lev 3:17).

Although meat eating may not be a big problem in Malawi, yet there is need to educate the people on its effects. They need to know what animal blood and fat do in the body system. The individuals are to make an intelligent decision after a presentation. If well handled, the people can see that lately there has been an increase in animal-related diseases and deaths. Sometimes, there have been announcements on the national radio to warn or even withdraw diseased meat. In most cases, it is too late. By the time such radio announcements are made, the people have already eaten the unhealthy animal meat. People are aware of these cases and are ready to listen.

The new disciples are to be introduced to the vegetarian diet. As for Malawi, it is mostly natural and less expensive compared to meat. The problem is substitutes. The educator should spend time to teach preparation of palatable healthy dishes.

Along with proper diet, a holistic health education should include the importance of clean water, pure air, sunshine, exercise, rest, abstinence, and trust in God. There is a misconception regarding the vegetarian diet. Some people think that when you become a vegetarian, you cannot fall ill to animal-related diseases. This is not God's promise. 3. Entertainment. The biblical principle is to avoid making a provision for the body (Rom 13:11-14). People of the Spirit are to develop healthy minds (Rom 8:5). Today, 
entertainment is a big business in the world. Some of the amusements appear to be innocent. Satan gains control of the minds in these unsuspecting worldly entertainments. ${ }^{1}$ Disciples need education in these lines of activities and a willingness to shun places of evil.

Discipleship is costly. There is a price one has to pay. It is the life of self-denial because the road is narrow and has a small gate (Matt 7:13-14). Disciples must deny themselves and take up the cross of Jesus daily (Luke 9:23). Greg Ogden explains what it means to deny self. "To deny yourself means to deny your self-lordship. It means saying no to the god who is me, to reject the demands of the god who is me, to refuse to obey the claims of the god who is me. A decisive no-'I do not know Lord Me-I do not bow down to him or her anymore."'2 Paul found this to be a daily struggle (Rom 7:2125). This is why growing in Christ is a daily continuous work.

Spiritual growth is not automatic. It calls for an intentional effort on the part of the believer. God calls the disciples to surrender their bodies to Him as a living sacrifice (Rom 12:1). A biblical Christian lifestyle is a powerful witness for God. People who have a healthy mind and body are more receptive to God's message. They are better prepared to recognize subtle strategies of the devil. They have power to shun evil and overcome the devil.

All these efforts are meant to nurture the new disciples to full spiritual growth.

${ }^{1}$ Ellen G. White, Selected Messages, vol. 3 (Washington, DC: Review and Herald Publishing Association, 1980), 332

${ }^{2}$ Greg Ogden, Discipleship Essentials: A Guide to Building Your Life in Christ (Downers Grove, IL: InterVarsity Press, 1998), 28. 
It is equally important for the church to form friendships with the new people and assimilate them into the various ministries of the church. Recreation, fellowship meals, health and family life seminars are some of the ways to assimilate the young in faith. The old members who are assumed trained by now, will be the ones to continue bonding with the new disciples. The new cycle of leading others to Christ begins again.

\section{Leading a Soul to Christ}

Leading a person to Christ is a rewarding experience to be desired. It calls for an attitude of prayer all the time. There might be more than one way of leading souls to Christ. The important thing is for individual disciples to find what works better for them. This knowledge to know what works better will come by experience. Situations may also impose changes or adaptations. A personal testimony is an effective tool in leading persons to Christ. Every disciple needs to have a conversion experience before trying to lead others to Christ. The conversion experiences differ from one person to another. Not everybody has a dramatic conversion experience like apostle Paul had (Acts 9:1-31). There are also people like apostle Peter whose real conversion experience comes long after being Christians for years (Luke 22:31-32).

A positive attitude is a factor in disciple-making. People are uncomfortable to open up to someone they do not really know. One of the first things to do in leading a person to Christ, is forming a genuine relationship with the individual. Pray to gain their confidence and trust. There are lonely and hurting people who are looking for peace, love, and salvation. "Many people than we think are longing to find a way to Christ."

${ }^{1}$ White, Gospel Workers, 158. 
The Lord places these truth seekers in the way of His children. Therefore, disciples should be good listeners and skillful fishers of men and women. They will catch these seekers at the right time, the point of their need. The most important thing is to have the experience itself personally.

The meeting and the development of the conversation between Jesus and the Samaritan woman at Jacob's well is a good example of leading a soul to Christ (John 4). There are some principles to be drawn from this story. The principles are not meant to be exhausted. They are to serve as basics in leading a soul to Christ.

1. Break prejudice. As a Jew, Jesus knew that Samaritans were their bitter enemies. They had no dealings except in case of real necessity. The disciples are not to be caught in national traditions which are contrary to the gospel. Every soul should be seen as a candidate of heaven. Nobody is to be bypassed.

2. Arouse interest. Christ requested for water, "a favor no Oriental would withhold." The woman's interest was aroused by the sincere request coming from a national enemy. For Jesus, this was a divine tact and a key to her heart. ${ }^{2}$ It made the whole conversation possible. Disciples ought to be tactful in all their dealings with people. This will enable the disciples to find openings to closed souls.

3. Physical water to spiritual. Jesus did not enter into a debate on the relations between the two nationalities. Instead, the request for physical water was an entering wedge to spiritual. Jesus moved the discussion to something of lasting value. The woman herself needed this spiritual water. Disciples should be wise enough to know

${ }^{1}$ White, The Desire of Ages, 183.

${ }^{2}$ Ibid., 184. 
when to make a switch from ordinary discussion to spiritual. Sometimes a mistake is made when people dwell too long on casual discussion. Eventually, they are not able to make a transition to the spiritual. In this way, potential prospects are lost. It becomes a waste of a golden opportunity. Turning casual conversations to spiritual is a discipline one has to learn and practice. It becomes natural with practice.

4. Meeting the created desire. The Master offered the gift of eternal life that would meet her desire. The woman expressed her desire for the gift. However, there were conditions to be met in order to get the offered gift. The contemporary disciples should be prepared to help the seekers of truth find Jesus.

5. Sinner's part. A sinner has to acknowledge her or his sin. All sins are to be confessed to Jesus who alone has power to forgive them. God wants specific confessions. "True confession is always of a specific character, and acknowledges particular sins."1 The sinner must decide to detach herself or himself from sin before attachment to Christ. God does not accept confession made without sincere repentance and reformation. ${ }^{2}$ Jesus did not attempt to change the condition of eternal life. It has always been perfect obedience to God's law. ${ }^{3}$ In this case, the woman recognized her need and acknowledged her sin.

6. Sealing the decision. The woman believed Jesus to be the Messiah. She left her pot and went to invite the whole village to come and see her newly found Messiah. When a person is ready to make a decision, there is no need for delay. The person needs

\footnotetext{
${ }^{1}$ White, Steps to Christ, 38.

${ }^{2}$ Ibid., 39.

${ }^{3}$ Ibid., 62.
} 
support and assurance of God's help. The one leading the person to Christ can begin to give support by commending the person for making a wise decision with no possibility of regrets later. The person will need continued prayers for the tough times ahead. Close with prayer. Give the person any relevant literature to help solidify the decision. It is also important to arrange time for next visit and series of Bible studies. Once this is done, it is time to leave.

If this visit was pre-arranged, one may have to deal tactfully with the host's offer of hospitality. There is almost always food to eat. To avoid offending the persons, it is best to eat. This makes the people happy. Failure to do so, may jeopardize the whole mission. This is a crucial visit especially if the person was not a close friend.

\section{A Personal Testimony}

Many writers advocate personal testimonies. Testimonies are powerful but should be used rightly. An effective testimony has three essentials. It includes life before becoming a Christian, how the person became a Christian, and what Jesus means now in the person's life. ${ }^{1}$ The person giving a testimony should avoid making sin appear attractive. Sin is always ugly and an intruder.

Regarding the conversion experience, Ellen White gives a summary of how to present it. "Tell those whom you visit the end of all things is at hand.... Tell them how you found Jesus, and how blessed you have been since you gained an experience in His service. Tell them what blessing comes to you as you sit at the feet of Jesus, and learn precious lessons from His Word. Tell them of the gladness and joy that there is in the

${ }^{1}$ General Conference of Seventh-Day Adventists, Witnessing for Christ (Washington, DC: Review and Herald Publishing Association, 1981), 47. 
Christian life. Your warm, fervent words will convince them that you have found the pearl of great price." This type of testimony breaks prejudice and encourages others to do the same and start enjoying life meaningfully. It takes away their fears.

\section{Mentoring New Converts}

The Oxford dictionary defines the word mentor as "an experienced and trusted adviser or guide, a teacher, a tutor." ${ }^{2}$ Christ met all these characteristics. Christ was a perfect mentor to His disciples. He was a loving, caring, and trusted Master. The disciples found in Him a trusted personal Friend. They failed Him many times but $\mathrm{He}$ was patient and understanding with them. They could not watch and pray when He was overwhelmed with sorrow and death in Gethsemane (Matt 26:36-46). They all left Him and Peter denied to have any knowledge or relationship with Him (Matt 26:69-75). They were still His friends who needed to mature. He did not once abandon them.

Mentors need commitment and sensitivity to the feelings and needs of their mentorees. This being the case, discernment is another important characteristic for the mentors. It helps to see the potential in the mentoree. ${ }^{3}$ Realization of the untapped potential in another individual is in itself an incentive for the mentor. Coaches in various fields of sports tend to work hard on gifted trainees who are underachievers. This challenges the mentoree to do more too. As the result of hard work by both, they share the joy of success. Christian coaches would experience the same with their trainees. In

${ }^{1}$ White, Evangelism, 485-486.

${ }^{2}$ The New Shorter Oxford English Dictionary (1993), s.v. "mentor."

${ }^{3}$ Jack Ridlehoover, "The Joy of Mentoring," Church Administration 42, no. 7 (April 2000): 24. 
fact, their joy would continue beyond this world and throughout eternity.

Bobb Biehl says it is a misconception to think that mentors are perfect. ${ }^{1}$ Mentors are imperfect people who by God's grace strive to walk in the path of obedience following the example of the Lord Jesus. Mentors care enough about others and are committed to see every "protege reach her or his God-given potential."2

Mentoring is assisting others in the areas of their needs to mature like yourself. It is not feasible to have one single curriculum for all because everything is based on the protege's "agenda, priorities, questions, and needs." The adviser guides the upcoming disciples into daily devotions, sharing their faith, preparation and delivery of sermons. It is also the responsibility of the mentor to help create service opportunities for them. The upbringing of such people go beyond baptism. That's why Chris Gnanakan says, "Mentoring is a mark of true spiritual maturity. It is watching God develop others through you and rejoicing that they are blessed and greatly used by God."^ Both the mentor and the new disciple experience growth at different levels. Biehl sees mentoring "as the critical link in developing, protecting, and optimizing Christian leaders for the next century." Mentoring develops strong future discipleship leaders for the churches.

${ }^{1}$ Bobb Biehl, Mentoring: Confidence in Finding and Becoming. One (Nashville, TN: Broadman \& Holman Publishers, 1996), 40.

${ }^{2}$ Ibid., 19.

${ }^{3}$ Ibid., 42.

${ }^{4}$ Chris Gnanakan, "Mentoring: The Way to Build God's Kingdom," Church Growth Digest 21, no. 4 (Summer 2000): 17.

${ }^{5}$ Bobb Biehl, xiv. 


\section{Discipling Beyond Baptism}

According to the Bible, the Christian life is a continuous experience of growth (1 Pet 2:2). "Christianity is more than an event, an experience, or a set of beliefs. It is a way of life characterized by moral seriousness and the quest for holiness."1 After baptism, the person needs to grow and develop to maturity. The period following baptism is a critical time. People are thirsty for the truth. On the other hand, trials and temptations are likely to intensify and increase. These factors make it the best time to provide the person with the necessary support and survival tools for coping.

As already mentioned, both the Old and the New Testaments show that the spiritual leaders were very involved in teaching ministry. Scriptures show that "instruction in the faith is essential to the spiritual growth of Christians and to the development of the church (Matt 4:23; Luke 4:14; Acts 13:1-3; Rom 12:6-8; Gal 6:6)."2 Continued discipleship helps to establish new members in the faith. Those who are wellgrounded will be better prepared to assist and nurture others in the Christian faith. In this way, the the number of active disciples will be multiplied.

\section{Personal Daily Devotion}

Consecration of self to God is the first Christian duty at the beginning of the day. "This is a daily matter. Each morning consecrate yourself to God for that day. Surrender all your plans to Him, to be carried out or given up as His providence shall indicate. Thus day by day you may be giving your life into the hands of God, and thus your life will be 2005,88 .

'David P Gushee, "Our Missing Moral Compass," Christianity Today, November.

${ }^{2}$ Nelson's New Illustrated Bible Dictionary (1995), s.v. “Teaching." 
molded more and more after the life of Christ." This admonition from Ellen White is a spiritual formula for starting a victorious day with Jesus.

As already covered in this paper, a personal devotional can be enriched by reading and praying. This may include personal secret prayers (Matt 6:6). It is during these sessions with God, when one can fully open the heart and tell the Father what cannot be said in public. It is the best time to tell God the heart's desires, praises, struggles, and temptations. This ritual energizes. The disciples are Spirit-driven. They are on a safe path to victory. Personal devotions prepare individuals for the day's experiences. On a practical note, the apprentice may read a Bible passage, a devotional book, a portion from the weekly Sabbath School lesson guides, or any such materials.

Part of the daily surrender is for the disciples to ask God to use them in His service. $^{2}$ The surrendered life is to be sustained by keeping an attitude of prayer at all times. It also entails being watchful for opportunities to share the good news of salvation. The disciple must learn to trust in God's promises, guidance, and faithfulness.

\section{Sharing Christian Joy with Others}

Sharing anything means being unselfish and having a caring attitude for others. People who share what they have, increase their capacity to receive more (Prov 11:2425). When disciples share Jesus with others, it multiplies their joy. On the other hand, the recipient praises God for sending Jesus and the free gift of salvation.

It is easy to be satisfied with finding the truth for oneself and do nothing about others. Jesus told the healed demon-possessed man to go home and tell his family what

${ }^{1}$ White, Steps to Christ, 70.

${ }^{2} \mathrm{Ibid}$. 
Christ had done for him (Mark 5:19). Although the person had not received instruction as the disciples, yet his healing was the evidence that Jesus was the Messiah. ${ }^{1}$ Witnessing for Christ is experienced-based. It is a personal testimony of what Jesus has done in a person's life. This means that everyone who has been touched by the grace of God has a powerful witness to the world. ${ }^{2}$ Disciple-makers have a mission to declare God's glory among the nations and His marvelous deeds (Pss 96:3).

The disciple makers have a mandate to share their joy in Christ with others. It is a love-driven desire to wish others to experience the satisfying joy of Christ. The disciples become ambassadors of Christ ( 2 Cor 5:20). Whoever experiences the joy, extends the invitation to others too. The discipleship circle grows while the joy is multiplied in many lives and it is deepened in those who are actively sharing their joy.

People are tired of hearing the news of violence and crime, starvation, racial hatred, family breakdowns, conflicts and wars among the nations. ${ }^{3}$ They are waiting to hear the good news of Christ's love and grace shown in His sacrificial death to save them from sin and eternal death (John 3:16; Rom 5:8, 6:23; Titus 2:11). Jesus sends His disciples with this good news of salvation to all the nations.

\section{Creating Opportunities for Ministry}

Jesus trained His disciples and created opportunities for them to minister. He kept His disciples always busy. He sent them out with power to heal every disease (Matt

${ }^{1}$ White, The Desire of Ages, 340.

${ }^{2}$ Ibid.

${ }^{3}$ Selwyn Hughes, The Introvert's Guide to Spontaneous Witnessing (Minneapolis, MN: Bethany House Publishers, 1983), 7. 
10:1). In the feeding of the five thousand people, He created an opportunity for them to organize and serve the people. He further assigned the disciples to pick up the leftovers (Matt 14:19-21). New members may not know how to find ministry opportunities. It is the duty of the mentors to find work for them. Discipleship coaches are supposed to be good resource persons, well-versed with the needs of the church, and the community. As they acquire experience, they will be able to find opportunities for themselves.

Mentors are active participants in the discipleship strategy. They have a voice, influence, and are invested with authority to train and utilize the disciples in new ministries. Sondra Higgins Matthaei says, "An important calling of a faith community is to provide ways for people to participate in a ministry of faith-mentoring using their Godgiven abilities."' Good mentors know the development level and the ability of their apprentices. With this knowledge, a wise mentor shares some of the work load with the protege while taking into consideration the ability of the person.

Some of the priority places in need of mentors include the newly baptized, the Bible class members, and an interest co-ordinator could help by providing a list of names of the backsliders. In addition, there might be people who attend church regularly but are not baptized members of the church. Some could be spouses of committed members of the church. The Voice of Prophecy students provide another area of service opportunity. This is also true of the regular readers of the church literature.

There are opportunities for ministry everywhere. It is a matter of prayer and being attentive to the prompts of the Holy Spirit. There is always need to prioritize the people to

\footnotetext{
${ }^{1}$ Sondra Higgins Matthaei, Faith Matters: Faith-Mentoring in the Faith Community (Valley Forge, PA: Trinity Press International, 1996), 117.
} 
work with because some are more ready than others. The apprentice mentoree should be adequately prepared to serve the needs of the church and community.

\section{Sermon Preparation and Delivery}

Churches will expect much from those who receive special training in discipleship. They will be called upon to preach on different occasions. Sometimes, it will be at the spur of a moment. However, the sermon preparation and delivery in this context is primarily intended to establish the participants in the disciple-making ministry. The skills will also help in preaching assignments from pulpits, at funerals, and other situations. The sermons will be short and simple for easy grasp by the majority of members in the rural areas who have little or no formal education. Some of these people memorize sermons. Someone in the audience reads the verses from the Bible and they comment on them.

The disciples are expected to know and to preach the truth as it is found in the Bible. People need to know God's character and attitude towards sinners. Christ is to be the center of all sermons. "Lift up Jesus, you that teach the people, lift Him up in sermon, in song, in prayer." The songs and prayers are supposed to contribute to the exaltation of Christ. It takes planning and great care to come up with a unified approach that magnifies Jesus.

Preaching makes a high demand on the preacher's life. "The sermon is the result of so much more than the time and effort actually expended in producing it. It is the result of the preacher's entire spiritual life, the preacher's moral convictions, the preacher's personal experiences and relationships, the preacher's reading and reflection, even the

\footnotetext{
${ }^{1}$ White, Gospel Workers, 160.
} 
preacher's health and diet."1 The preacher's appearance, language, communication skills, gestures, illustrations, and relevance of the message are among the factors that contribute to the effectiveness of the sermon. The Bible is the main tool in sermon preparation. According to David Read, it is also important for the preacher to know the audience. ${ }^{2}$ It helps with being relevant in meeting the felt needs of the people.

The call to discipleship is deeply rooted in the Scriptures. Every disciple needs to know that God is behind his or her call. Their mission is to preach the kingdom of God. It was for this reason that Jesus sent out His disciples to preach (Mark 3:14-15). They proclaimed about the nearness of the coming kingdom of God (Luke 10:9). In the Great Commission, Jesus repeats the importance of teaching the things He commanded them (Matt 28:19). Preaching is part of disciple-making.

Regardless of the length and occasion, most sermons have an introduction, body, and a conclusion. The preacher can hold or lose the attention of the audience during the sermon introduction. It needs to be brief but carefully crafted. Short sermons tend to attract the attention of the people and help to preserve the health of the preacher as. ${ }^{3}$ See appendix A for five short topical sermons. The sermons are meant to be part of the discipleship curriculum during the training of the mentors and trainers.

${ }^{1} \mathrm{John}$ Killinger, Fundamentals of Preaching (Philadelphia, PA: Fortress Press, 1985), 188.

${ }^{2}$ David C. Read, Preaching about the Needs of Real People (Philadelphia, PA: The Westminster Press, 1988), 72.

${ }^{3}$ White, Evangelism, 177-178. 


\section{Monitoring}

Successful and progressive church leadership enables people to move from intention to achievement. ${ }^{1}$ The measure of effective leadership is in its success to fulfill its mission and reason for existence. Such leadership is mature enough to critique itself and is willing to make necessary changes. It detects mistakes early and prevents them from paralyzing the whole ministry. It is also open to healthy criticisms. Monitoring is like having deep listening ears to the heartbeat of the ministries. It is like Jesus asking what people said about Him and Paul's follow up visits (Matt 16; Acts 14:21-28).

Discipleship strategy needs to be monitored because everybody becomes a learner. The leader may learn from the apprentices something new or how to do things differently and effectively without flouting principles. There is also the aspect of adaptation of the strategy depending on the factors and circumstances in that location. Even within Malawi, there are differences between the city and the rural churches. In the city, the literacy rate is higher than in the rural. The working class has time constraints unlike the self-employed peasants who live in the rural. These kind of dynamics could give different results of discipleship strategy.

Willingness to learn something new and unlearn something old is an evidence of growth. ${ }^{2}$ The envisioned monitoring in this case is a simple one where both personnel and their ministries are tested for effectiveness. The areas to look at will be in accordance with this discipleship strategy. The increase of disciple-making Christians and the development

${ }^{1}$ Kevin Treston, Creative Christian Leadership: Skills for More Effective Ministry (Mystic, CT: Twenty-Third Publications, 1997), 6.

${ }^{2}$ David Wiersbe \& Warren W. Wiersbe, Making Sense of the Ministry (Chicago, IL: Moody Press, 1983), 122. 
of leadership in the local churches are the minimum factors ${ }^{1}$ to be monitored. Regardless of the geographical location of the churches, the minimum factors will be the same. Attention to the minimum factors does not mean totally ignoring the other growth factors mentioned or alluded in this research. Each church is responsible to make specific annual goals for its rate of growth. These goals are to be monitored quarterly.

For the strategy to be called effective, there must be an increase in the number of trained and participating Christians as disciples. These disciples are supposed to parent every new member until they are able to lead another soul to Christ. In addition, the process of mentoring new members will also improve leadership base in the local churches. In the end, monitoring is an honest way of looking at the effectiveness of the pastor's work and the impact of discipleship structures on the Great Commission goals.

\section{Summary}

Disciple-making is a tested and proven strategy for reaching the world with the gospel. When introduced in its full scope, disciple-making covers components of education of the established and new members and provides modeling for the new converts in their growth through the habits of Bible study, prayer, lifestyle, and witnessing. The strategy revives and renews church life so that every member becomes an active participant in the mission of the church.

Mentors play a critical role in disciple-making strategy. They serve as role models and guide the proteges in their spiritual journey to maturity. Disciple makers meet people of different faiths and ideologies. People seem better to respond to a personal testimony

${ }^{1}$ Schwarz, Natural Church Development: A Guide to Eight Essential Qualities of Healthy Churches, 108. 
of a transformed life. A well presented Spirit-filled testimony arrests people's attention and challenges them to do the same knowing they have somebody to assist them.

The mentors provide the apprentices a support system which includes creating ministry opportunities for them. In this way, the new disciples are able to get "hands-on" experience. These internships help the new disciples to discover and to develop their spiritual gifts and their place in the disciple-making.

Disciple-making education enlightens the church members and aids the whole congregation in its growth in the knowledge of God and what He requires of them. Leading others to Christ and sermon preparation are part of the educational curriculum. These two basic skills prepare the laity for leadership in the local churches where they often preach. "A training program that encourages lots of practice and helps participants examine mistakes is usually more developmental than one that provides information but no practice." This model of disciple-making is more practical and valuable. The participants learn from their mistakes. They work to improve on those weak areas.

Monitoring the system prevents laxity and the attitude of business as usual. To avoid this from happening, there is need for regular monitoring to test the effectiveness and relevancy of all the ministries. Monitoring puts measures for checks and balances in the disciple-making process. It helps to consistently focus on the big picture and the mission of the church. At the same time, monitoring provides a mechanism for adjustment in the activities as they relate to the Gospel Commission in a community.

${ }^{1}$ Cynthia D. McCauley and Ellen Van Veslor, eds., The Center for Creative Leadership Handbook of Leadership Development (San Fransisco, CA: Jossey-Bass, 2004), 3. 


\section{CHAPTER 5}

\section{DISCIPLESHIP TEACHING STRATEGY}

\section{Introduction}

A strategy is only good enough if it produces the desired results. Christ's proven discipleship model addresses God's mission to reach all the nations of the world and people of all ethnic backgrounds with the good news of salvation. This is God's pressing agenda. The great Gospel Commission is Christ's call on the church to follow the strategy to the letter. Each local church needs to develop its own suitable working plan as it seeks to implement the strategy of discipling all nations.

The responsibility of implementing discipleship strategy was left with the apostles who "were given a unique ambassadorial office of authority and spokesmanship for Christ." The church needs to view itself as a foreign office whose major function is "to help people become citizens of heaven."2 In this regard the church becomes the center for dissemination of the requirements for citizenship in God's heavenly kingdom.

As already mentioned in this paper, pastors and lay persons can work side by side

${ }^{1}$ John MacArthur, Twelve Ordinary Men: How the Master Shaped His Disciples for Greatness and What He Wants to do with You (Nashville, TN: W Publishing Group, 2002), xvi.

${ }^{2}$ John Mark Terry, Church Evangelism: Creating a Culture for Growth in Your Church (Nashville, TN: Broadman \& Holman Publishers, 1997), 2. 
to fulfill their biblical roles in the Gospel Commission. They stand equal as complimentary partners in the task of making disciples. Both groups need advanced training to enable them perform effectively in their respective ministries. They need special expertise in disciple-making.

Jesus trained His disciples thoroughly and was able to say to His heavenly Father, "I have taught them all that I learned from thee, and they have received it" (John 17:8 NEB). "Jesus told his Father what he had been doing for the last three years: preparing his disciples to live for God's purposes. He helped them to know and love God (worship), taught them to love each other (fellowship), gave them the Word so they could grow to maturity (discipleship), showed them how to serve (ministry), and sent them out to tell others (mission)."'

The disciples were further empowered by the commission. At the same time, Christ's systematic training of the twelve disciples was the secret behind His successful rescue mission to this planet. Alexander Balmain Bruce "speaks of the training $\mathrm{He}$ [Jesus] had given these men as if it had been the principal part of His own earthly ministry. And such, in one sense, it really was. The careful, painstaking education of the disciples secured that the Teacher's influence on the world should be permanent; that His kingdom should be founded on the rock of deep and indestructible convictions in the minds of the few, not on the shifting sands of superficial evanescent impressions on the minds of the many."2 Jesus put all His life in the training of the twelve disciples. They

${ }^{1}$ Warren, 310.

${ }^{2}$ Alexander Balmain Bruce, The Training of the Twelve or Passages Out of the Gospels: Exhibiting the Twelve Disciples of Jesus Under Discipline for the Apostleship (Grand Rapids, MI: Zondervan Publishing House, 1963), 13. 
caught their Master's influence and spread it.

Discipleship advanced training is intended to be the beginning of developing local church leadership to be charged with the implementation of the disciple-making strategy. The aim is to eventually have a network of trainers in all the local churches. The training will be enriched by a provision of hands-on experience led by the trainers, which is the most effective way of preparing apprentices for discipleship. The trainees watch their mentors at work.

As far as possible, consideration is to be given to age, gender, location, and status of the participants. Those who faithfully attend and complete the training will be awarded certificates. It is hoped that these certificates will help to give them recognition and some degree of status elevation so that other lay persons will listen to them. This will also motivate others to join the training. However, as Leroy Howe says, "Training must be completed satisfactorily, and not just completed, for commissioning to be warranted."1

\section{Leadership Recruitment}

In leadership, there seems to be two groups of people. There are those who aspire to be leaders which is an honorable ambition (1 Tim 3:1 NEB) and others who do not aspire at all. The aspirants may not be well-disciplined, credible, and effective. Yet, the quest for good leadership seems to be the cry of many mission-driven organizations around the global including the church. Leaders of Nehemiah's caliber are scarce. 'Nehemiah's whole soul was in the enterprise he had undertaken. His hope, his energy,

${ }^{1}$ Leroy Howe, A pastor in Every Pew: Equipping Laity for Pastoral Care (Valley Forge, PA: Judson Press, 2000), 179. 
his enthusiasm, his determination, were contagious, inspiring others with the same high courage and lofty purpose. Each man became a Nehemiah in his turn and helped to make stronger the heart and hand of his neighbor."'

Nehemiah's approach was to meet with the leaders of the people first. He shared with the priests and nobles his concern and enlisted their co-operation and participation (Neh 2:17-18). "Although Nehemiah bore a royal commission requiring the inhabitants to co-operate with him in rebuilding the walls of the city, he chose not to depend upon the mere exercise of authority. He sought rather to gain the confidence and sympathy of the people, well knowing that a union of hearts as well as hands was essential to success in the great work which he had undertaken."2 Nehemiah realized that the priests had great influence and had a key to reach the masses at the grassroots whose ongoing support he needed. His game plan was to gather accurate information about the exact condition and needs of the work first and then meet with the priests.

It needs to be noted that primarily, Nehemiah relied on God (Neh 2:20). This is the key to all successful leadership and more also in disciple-making. Disciple makers respond to Christ's call for their service. Leaders who know that the work belongs to God have no illusion about their role. They are humble and ready to give God the credit.

Recruitment of leaders is best done in consultation with the local church. The members of a local church know one another well. Timothy, who turned out to be a most trusted companion of Paul; was recruited on the recommendation of "the brothers at

${ }^{1}$ Ellen G. White, Prophets and Kings (Boise, ID: Pacific Press Publishing Association, 1943), 638.

${ }^{2}$ Ellen G. White, Christian Service (Washington DC: Review and Herald Publishing Association, 1983), 174. 
Lystra and Iconium" (Acts 16:2). They spoke so well of him. Timothy proved to be what the local churches said about him. He was a good recruit. He demonstrated deep commitment to his work.

The local church is the main player in disciple-making. Discipleship strategy will be well served if from inception the local congregation gets the sense of ownership. It is advisable to work hand-in-hand with the churches. Best recruits are usually a result of honest assessment and recommendation from the local people. As far as formal education is concerned, the church members may be uneducated but have the best of the church at heart. It is important to listen to what the members say about their fellow believers. In most cases, soon or later it turns out to be a fair assessment of their own people.

Psychologically, nobody wants to be identified with failure. When people feel strongly to have the sense of ownership, it motivates them to put extra effort to achieve their goals. It seems to be human nature that people tend to give full support to something they personally identify with. The best thing is to involve them from the planning stages. They make sure the thing succeeds. Disciple-making cannot ignore this human behavior.

\section{Steps for Strategy Implementation}

The first step in the implementation of the Malawi disciple-making strategy is to win the support of the union and the field officers. The officers hold a key to the success of this agelong, Bible-based strategy. They have forums for addressing the pastors and the lay persons in their respective yearly meetings. In Malawi Union the administrators conduct ministerial and church officers' meetings at the beginning of every year for the 
newly elected local church officers. This is an excellent time for discipleship training.

All the pastors in Malawi are usually gathered together in one place or in their field territories at the beginning of every year for the ministerial workers' meetings. They look forward to ten days of fellowship, promotional goals for that year, year-end recommendations, policy education, short seminars, and inspiration from the worship. After the ministerial meetings, the union and field personnel go to the designated district centers to train the local church officers elected for that year.

These forums present an opportunity to sensitize the officers, departmental directors, the district pastors, and the elected lay persons on the urgency of radical disciple-making. On Sabbath the whole congregation joins. This forum alone touches the members at the grass-roots level. The impact is unimaginable.

\section{Unity in Vision Articulation}

A clear articulation of Christ's vision for finishing the work through disciplemaking strategy will in a large measure contribute greatly to the results. Vision clearly distinguishes leadership from management. "The single most important thing a leader can do to his or her followers is to provide the vision. How well the leader articulates the vision and how well the followers understand the vision are key to the success of any endeavor." If the pastors and the serving officers in all the departments of the local church shared a common vision, the church in Malawi would be renewed and could turn the whole country upside down. This is possible if the vision is implemented systematically.

${ }^{1}$ George Pejakovich, "Leadership Focus: The Importance of Vision," The Army Chaplaincy (Winter 1998): 3. 
The leadership has to be really committed and continuously remind people at every occasion about disciple-making. The leader's words must match deeds in every respect consistent with the vision. A leader must communicate his or her vision. ${ }^{1}$ One way is for the leader to be personally involved in disciple-making. In addition, committed leadership would work tirelessly to fund budgets for discipleship.

Sometimes leaders confuse people when they promote too many things at once. The church members are left in the air not knowing what takes priority. The members are wise enough to detect heartless disciple-making promotion. Much can be accomplished if the message of the vision is consistent.

Disciple-making strategy has a force to unite the whole church. One way to keep the flame and the unity is to share whatever is happening elsewhere in the union. This inspires people and motivates them to do more on their part. It creates a new awareness. "At the heart of Christian identity is commitment to Christian vocation-love of God and love of neighbor."2

\section{Selection Process}

Major sports teams attach great importance in their efforts to recruit the best players. They "comb the minor league teams for possible draft picks, churches need to seek out and recruit the best people they have to serve in missions." ${ }^{.3}$ Jesus did not leave

\footnotetext{
${ }^{1}$ William E. Rosenbach and Robert L. Taylor, Contemporary Issues in Leadership (Boulder, CO: Westview Press, 1993), 83.

${ }^{2}$ Sondra Higgins Matthaei, Making Disciples: Faith Formation in the Wesleyan Tradition (Nashville, TN: Abingdon Press, 2000), 22.

${ }^{3}$ Tom Telford, Missions in the $21{ }^{\text {st }}$ Century: Getting Your Church into the Game (Wheaton, IL: Harold Shaw Publishers, 1998), 41.
} 
it to the people to volunteer. He chose them and prayed for them. ${ }^{1}$

While great care is to be exercised in the selection of leaders, yet those charged with the responsibility ought to be prepared to take risks in trying potential upcoming young leaders. The selection process has room for discernment of hidden potential in the emerging leaders. As mentioned, some members may not verbally express their desire for leadership. Until they are approached, some people do not want leadership work except if asked. Sometimes it is because people may not recognize their own leadership abilities until someone discovers them and gives them support and an opportunity to lead. ${ }^{2}$

It is better to avoid recruitment of leaders through announcements from the pulpit and church bulletin because one either gets no people or the wrong people. ${ }^{3}$ The members are offended when they respond to the pulpit announcements but are ignored. It becomes sensitive to tell them why they are sidelined. This affects them in their faith.

"Against the truth that congregations should offer their best people to God is the truth for the individual that God's strength is made perfect in weakness (2 Cor 12:7-10) and God produces some of the most spectacular results using the most unlikely resources." ${ }^{.4}$ Moses felt unfit for the work but turned out to be one of the most outstanding leaders Israel had. He depended on God entirely and was rewarded.

${ }^{1}$ Ibid., 42.

${ }^{2}$ Edgar J. Elliston, Home Grown Leaders (Pasadena, CA: William Carey Library, 1992), 113.

${ }^{3}$ Aubrey Malphurs and William Mancini, "Building Leaders: Blueprint for Developing Leadership at Every Level of Your Church (Grand Rapids, MI: Baker Books, 2004), 68.

${ }^{4}$ Terry Young, After the Fishermen: How Did Jesus Train His Disciples? (Carlisle, Great Britain: Paternoster Press, 2004), 9. 
The church that recruits the best, spends time in prayer seeking God's guidance, e.g., when the disciples replaced Judas with Matthias (Acts 1:20-26). It can be concluded that through prayer, the choice of the replacement was left in God's hands. ${ }^{1}$ After selection, the church trains and sends its members to make disciples. Training is the initial requirement of the Gospel Commission. It is also true that "when the church/congregation has strengthened its leadership in knowledge and power it will be the congregation members together taking the initiative in deciding how the gospel needs to be incarnated in their own particular context."2 This kind of involvement will also address the question of authenticity.

\section{Successful Discipleship with Ten People}

There is nothing mystical about the proposed number of ten people. It is based on the principle that a small group is easier to work with. It is more effective in its accomplishments of the goals. As such, "we should not expect a great number to begin with, nor should we desire it. The best work is always done with a few. Better to give a year or so to one or two people who learn what it means to conquer for Christ than to spend a lifetime with a congregation just keeping the program going. Nor does it matter how small or inauspicious the beginning may be; what counts is that those to whom we

${ }^{1}$ Nelson P. Estrada, From Followers to Leaders: The Apostles in the Ritual of Status Transformation in Acts 1-2 (London, Great Britain: T \& T Clark International, 2004), 185.

${ }^{2}$ Timothy Nyasulu, Missiology: A Study of the Spread of Christian Faith (Zomba, Malawi: Kachere Series, 2004), 89. 
do give priority in our life learn to give it away."

Another advantage of starting with a small number of people is its manageability. The trainers are able to work with the whole group and still give special attention to individual needs. This makes it possible to develop every individual member of the group. As a result, the whole group receives quality training. The small group develops family spirit. It is human nature to need caring friends to share with them "frustrations, uncertainties, hopes, and prayers." ${ }^{2}$ It is easier to follow up on any member who misses the training.

A small group tends to develop a team spirit which is an essential factor in disciple-making. "No one can come to Jesus and remain alone. Every believer becomes a part of a company of faith. This is visibly experienced in the group that follows Him and in the little clusters of the faithful wherever He goes." When people work together in disciple-making, they are united by a bond of love and pursuit of a common goal. Some faith relationships become stronger than biological ties. Pastoral leadership can intentionally connect people and make them more united. A formation of a small united front for noble Christian ideals for propagation of the gospel has better chances to succeed in its endeavor.

\section{Skill Development for Pastors}

Although seminary training prepares a person for pastoral ministry, yet there is still

${ }^{1}$ Coleman, The Master Plan Evangelism, 109.

${ }^{2}$ Howe, 168.

${ }^{3}$ Coleman, The Master's Way of Personal Evangelism (Wheaton, IL: Crossway Books, 1997), 157. 
much more a person has to learn outside the classroom. In some cases, as Bill Hull points out, there are professors who teach seminary students when they themselves have no pastoral experience. ${ }^{1}$ It takes personal effort for an individual to develop and acquire practical pastoral expertise. This is achieved on the job itself. Experience plays a major role in one's development. After all, "the best training is doing; the way to learn is to begin; the way to knowledge is by experience, and the way to get experience is by doing the work." ${ }^{2}$ This simply means that pastors should not wait until they are trained in disciple-making. Pastors are the ones who initiate the whole disciple-making ministry.

As already mentioned, any effective and successful pastor makes disciple-making his or her ministry's top priority. By training lay people, the pastor achieves high membership quality without placing heavy demands on the church budgets. ${ }^{3}$ These members are able to do the work that could have been done by a paid person. It also helps church members to do their work with confidence. Pastors need a concentrated training that equips them to be trainers in their local churches. Much of the work with the pastors has to do with their motivation to look at the revolution of disciple-making.

The pastor needs to know how to motivate and teach people about a larger and challenging objective that nobody can claim to reach a finishing line. ${ }^{4}$ The objective is worth a person's commitment. There are four hooks to this larger objective which Jesus

${ }^{1}$ Bill Hull, The Disciple Making Pastor (Old Tappan, NJ: Fleming H. Revell, 1988), 46.

${ }^{2}$ Alfred M. Wagner, Training the Laity for Personal Work (Columbus, $\mathrm{OH}$ : Lutheran Book Concern [n.d], 22.

${ }^{3}$ Howe, 146.

${ }^{4}$ Hull, 106. 
taught and repeated over and over in His ministry to the disciples and the various congregations. According to Christ's teaching, the kingdom was the model, the cross was the means, the commission was the method, and His coming was the motive. ${ }^{1}$

Systematic disciple-making works to arouse, equip, and engage the already positioned pastors in the fulfillment of their high calling to the ministry of reproducing productive disciples. In this case, every pastor will be trained in the basics of disciplemaking. "He who would instruct others must himself be a personal worker. The pastor must love souls sufficiently not only to preach sermons on Sunday and to attend to those who are brought to his attention, but to also seek opportunities of speaking to individuals wherever they may be."2

The responsible departmental directors from the union and the field offices will assist the pastors with material resources, additional trainers, and follow-up sessions to make sure the discipleship strategy set goals are fully met.

\section{Basic Training for Lay Persons}

A number of Christ's disciples and people who came for healing, including the ten lepers who could not have come since they were outcasts of the society, were a result of personal labor. ${ }^{3}$ Those who took them to Jesus were engaged in personal work which was telling others the joy and peace they themselves had found in Christ. Introducing people to Christ requires some skills. Sad to say that the church has not aggressively continued to

$$
\begin{aligned}
& { }^{1} \text { Ibid., } 107 . \\
& { }^{2} \text { Wagner, } 28 . \\
& { }^{3} \text { Ibid., 10-11. }
\end{aligned}
$$


produce personal workers to match the task. According to a 1980 Gallup poll, "Of the 22 million church-going evangelicals, only 7 percent had taken any evangelistic training and only 2 percent had introduced another person to Jesus Christ." Leadership has a responsibility to train the members. After adequate and appropriate training in the areas of their skills, the members have no excuse not to make disciples.

Since training has been lacking in most of the churches, one wonders how some congregations are growing. Hull points out that transfers, strong preaching, and great music programs account for the growth in most of the evangelical churches. ${ }^{2}$ There is need for the evangelical churches to adopt apostle Paul's motto to preach the gospel where Christ was not preached (Rom 15:20). Among some Christian groups in Korea, it is expected of new Christians to show the genuineness of their conversion by bringing another person to Christ. ${ }^{3}$ Reaching out to those who have not known Christ should be the burden of Christ's disciples. This can be done without ignoring the qualitative growth of the members.

The best time to get the attention of the new members and plant in them a lasting impression about the importance of disciple-making is at the beginning of their spiritual life. "We should ever leave upon the minds of the new disciples an impression of the importance of our mission." ${ }^{4}$ Pastors have an opportunity and responsibility to teach and allow the laity to discover and freely practice their ministry. The lay members need every

${ }^{1}$ Hull, 20.

${ }^{2}$ Ibid.

${ }^{3}$ Wagner, 12.

${ }^{4}$ Ellen G. White, Testimonies for the Church, vol. 3, (Mountain View, CA: Pacific Press Publishing Association, 1948), 210. 
support, prayers, encouragement, and advanced training.

The church in Malawi needs to share Paul's goal and in one united voice join the apostle saying, "We proclaim him, admonishing and teaching everyone with all wisdom, so that we may present everyone perfect in Christ" (Col 1:28). In this goal, the definition of a perfect Christian "is one who is able to stand alone under temptation, and able to spiritually reproduce."1 New believers are vulnerable to Satan's attacks and temptations.

\section{Advanced Training for Leaders}

Christ trained His disciples to be leaders of the church. The disciples gave strong Spirit-filled leadership to the church. The need for an advanced training for leaders is even greater today. The church is responsible to provide ministry leadership training to the laity it asks to serve. Failure to train the laity is injustice to them and the ministry. ${ }^{2}$ The scope of the Gospel Commission demands continued training of the lay leaders beyond the basics.

Training and spreading the teachings differentiates disciples from converts. ${ }^{3}$ It is for this reason that this strategy lays heavy emphasis on training and dissemination of the gospel. In this case, the training goes beyond the basics. The proposed advanced training targets serving pastors, seminary students, and ten highly selected lay persons at a time

${ }^{1}$ Charles "Chic" Shaver, Conserve the Converts: A Manual to Help Pastors and Laymen Conserve the Results of Personal and Mass Evangelism (Kansas City, MO: Beacon Hill Press of Kansas City, 1976), 65.

${ }^{2}$ Malphurs and Mancini, 27.

${ }^{3}$ Victor R. Brown, Disciple Ministry: Intergrating New Members into Church Fellowship, 1993 (?). Photocopy, 3, Lakeview Seminary, Ntcheu, Malawi. 
from each mission field. To begin with, the selected laity will be mainly from the urban churches in Blantyre, Lilongwe, and Mzuzu, headquarters for the field missions. It will be easier and cost-effective to train people within these three cities. Any keen disciple maker from the nearby towns will be given a special consideration.

The urban training sessions will run on week-ends from Friday evening to Sunday evening. The rural areas and townships will be any two days in the week.

TABLE 1

\begin{tabular}{|c|c|c|c|}
\hline \multicolumn{4}{|c|}{ TIMETABLE FOR DISCIPLESHIP TRAINING } \\
\hline Time & Friday & Sabbath & Sunday \\
\hline $6: 00-6: 30$ & & & Organized Sports \\
\hline $7: 00-8: 00$ & & \multicolumn{2}{|c|}{ B R E A K F A S T } \\
\hline $8: 00-8: 30$ & & Devotional & Devotional \\
\hline $8: 30-9: 20$ & & \multirow{4}{*}{$\begin{array}{l}\text { Sabbath School } \\
\text { and } \\
\text { Divine Service }\end{array}$} & Lecture \\
\hline $9: 30-10: 20$ & & & Group Discussion \\
\hline $10: 30-11: 20$ & & & Lecture \\
\hline $11: 30-12: 20$ & & & Preaching \\
\hline $12: 30-1: 30$ & \multicolumn{3}{|c|}{$\mathrm{L} \mathrm{U} \mathrm{N} \mathrm{C} \mathrm{H}$} \\
\hline $2: 00-2: 50$ & & Lecture & Lecture \\
\hline $3: 00-3: 50$ & & Group Discussion & Lecture \\
\hline $4: 00-4: 50$ & & Hands-on Training & Hands-on Training \\
\hline $5: 00-5: 00$ & & Hands-on Training & Hands-on Training \\
\hline $5: 45-6: 25$ & \multicolumn{3}{|c|}{ S U P P E R } \\
\hline $6: 30-7: 00$ & Vespers & Vespers & \\
\hline $7: 00-8: 00$ & Lecture & Lecture & \\
\hline
\end{tabular}


The teaching style will be a mix of lectures, discussions, and practical training. A fifty-minute lecture time period will be divided into three parts. The trainer will lecture for twenty minutes. This will be followed by group discussions for another twenty minutes. The groups will give brief reports for the last ten minutes. This approach is partly taken in consideration of the fact that adult Christians have much to share. Their practical experiences will benefit everybody and bring enrichment to the program.

More time is allocated on Sabbath and Sunday for group discussion and the handson experience. This will be a good time to objectively and thoroughly examine some of the Malawian traditional rituals, practices, and for hands-on discipleship. The close examination of the rites will hopefully bring an outcome that reflects biblically fair assessment. The resolutions reached with the help of those who went through these initiations and also understand the gospel demands on a disciple, will be presented to the administrators as recommendations for their consideration. This honest dialogue is an attempt to sort out negative elements in the rituals from the positives in keeping with the Scriptures. It is hoped that this will minimize or get rid of the split level Christianity. The advanced training will be conducted in the mission field territories and at Lakeview Seminary. The pastors' meetings will coincide with the end of the month when most pastors come with their various monthly reports to the office. In this way, there will be no need for extra travel expenses. The administrators are more likely to consider this arrangement and timing with favor.

Stan Toler and others recommend the advanced training could cover various 
leadership styles, roles, and personality profiles. ${ }^{1}$ While all the leadership styles may be used effectively at different times, the democratic or shared leadership which is also known as the participatory ${ }^{2}$ seems to be an ideal leadership style for disciple-making. It falls between the two extremes of leadership ranges from the laissez-faire which is also known as passive or permissive and the autocratic or authoritarian. ${ }^{3}$

Christ taught and practised servant-leadership style (Matt 20:20-28). He stressed the importance of serving others with all humility. He even demonstrated it to the disciples' shock when He washed their feet in readiness for His last supper with them (John 13:1-17). The good response of the led to the servant-leader model is in proportion to how they view the leader's servant stature. ${ }^{4}$ Servant-leadership examples from the Bible will be used to enforce the effectiveness of this Spirit-filled leadership. This leadership style makes people receive orders without any feeling of humiliation. ${ }^{5}$ It is an ideal leadership style for disciple makers.

The advanced training will also take an in-depth study of the whole mission of the church. This will be done through the study of the Adventist Church history as a movement. It will help to put across clearly its mission mandate, success, and challenges.

'Stan Toler, Dan Casey, and Dan Walters, Growing Disciples: Equipping Christians for Worship, Fellowship, and Ministry (Kansas City, MO: Beacon Hill Press, 2000), 262.

${ }^{2}$ Louise W. Bloede, The Effective Pastor: A Guide to Successful Ministry (Minneapolis, MN: Fortress Press, 1996), 27.

${ }^{3}$ Ibid.

${ }^{4}$ Robert K. Greenleaf, Servant Leadership: A Journey into the Nature of Legitimate Power and Greatness (Mahwah, NJ: Paulist Press, 1991), 10.

${ }^{5} \mathrm{John}$ Adair, The Leadership of Jesus and Its Legacy Today (Cleveland, OH: The Pilgrim Press, 2002), 171. 
In this way, the church can recapture its lost passion as a disciple-making movement.

The people who go through this advanced phase of disciple-making training will be the trainers of the majority. The number of the trainers will be increased with time on a quarterly basis. The three major cities will continue to be the main suppliers of the candidates. From the cities, the recruitment of leaders will move to the townships. The plan is to ensure that every church member in the congregation is reached, trained, and given equal opportunity to participate in disciple-making.

\section{City Churches: Pioneers in Disciple-Making}

The laity from the city churches have much influence on the rest of the church membership in the rural areas. The lay members in Blantyre are a good example. The stewardship directors from the local churches initiated and formed a lay stewardship council. They worked in consultation with the field stewardship departmental director. Their main concern was lack of faithfulness in tithes and offerings among the members. ${ }^{1}$ They discussed among themselves, prayed about it, and came up with a ministry that has impacted the whole church.

They came up with a program which included a "Stewardship Sabbath Day" once a month. On this day, two local church's stewardship directors were assigned a church to preach a stewardship focused message. The rest of the afternoon was spent in Bible studies, group discussions, and prayer. On Sundays, they met to report, receive more

${ }^{1}$ These committees were made up of all the stewardship directors of the local churches in the city of Blantyre. They worked in consultation with the field offices under the co-ordination of the field stewardship departmental director. The model was adopted by all the other field missions and to all their churches. 
training, and sometimes went on door-to-door visitation in the townships.

The program spread to all the churches in the South Malawi Field (SMF). Later, the other two fields heard about it, invited lay speakers from the SMF to share with the churches in the Central and the North Malawi Fields (CMF and NMF). As a result of this lay-initiated ministry, two of the three fields applied to be surveyed for conference status (see appendix B). This is a testimony of the unexploited potential, influence, and power of the lay persons. Grass-root ideas have better chances to succeed. ${ }^{1}$ This is why the Malawi disciple-making model emphasizes the importance of the laity at the local church level. The idea of the City Stewardship Council began with the laity.

\section{Leaders in Teams of Two}

The lay trainers will be organized to work in pairs. This is the method Christ used when He sent out His disciples, including the seventy. "None was sent forth alone, but brother was associated with brother, friend with friend. Thus they could help and encourage each other, counseling and praying together, each one's strength supplementing the other's weakness. In this manner He afterward sent forth the seventy. It was the Savior's purpose that the messengers of the gospel should be associated in this way. In our own time evangelistic work would be far more successful if this example were more closely followed."

When Jesus sent out His disciples, they all declared one message about the nearness of the kingdom of heaven (Matt 10:7). The trainers will carry the same message

${ }^{1}$ William H. Willmon and Robert L. Wilson, Rekindling the Flame: Strategies for a Vital United Methodism (Nashville, TN: Abingdon Press, 1987), 98.

${ }^{2}$ White, The Desire of Ages, 350. 
wherever they will go. They will declare the nearness of the kingdom. Those who will accept the message will be nurtured to be deployed in the Gospel Commission.

The importance of the messenger's character involved in disciple-making cannot be over-emphasized. During the early stages of the disciples, "the concept of 'following Christ' is too abstract for them. They are interested in how a real flesh-and-blood Christian looks, acts and reacts, and as their spiritual parent, you're elected." "The character of the messenger is a factor in disciple-making. It challenges and holds the disciples to a higher standard. The new believers find such living testimonies more appealing, challenging, and encouraging. The new converts need big brothers and sisters.

The method of providing mentors to those young in the faith is the most practical way of developing biblical disciples. There are essential elements to consider. "Such things as age, sex, children, occupations, interests, religious backgrounds should be taken into consideration. The better the match between the convert and the worker, the more effective likely will be the relationship to be established." ${ }^{2}$ Suitable matching plays a part in the overall results.

\section{Age Consideration}

As much as possible, the ages of the disciple makers and the new converts will be taken into consideration. Disciple teams are more likely to understand and appreciate the pressures and challenges facing the learners of their age bracket. People tend to be more

${ }^{1}$ Christopher B. Adsit, Personal Disciple-Making (Nashville, TN: Thomas Nelson Publishers, 1993), 83; quoted in Andy and Kim Harrison, The Discipling Cycle Series: Seek, Share, Serve (Nashville, TN: LifeWay Press, 2002), 166.

${ }^{2}$ Shaver, 61 . 
open and free when put in the same age group, and seem to struggle with more or less the same problems. A wide age difference gap could threaten a meaningful communication.

Besides the age factor, similarities of how people came into the truth will also influence the match suitability. The best natural mentors are those who introduced the newborn Christian to the Savior. ${ }^{1}$ They usually have a keen interest and commitment to see their friends grow to spiritual maturity.

The other possible group of mentors are those who may have some similarities in their conversion experiences. For example, some disciple-makers may be current or former classmates, workmates, or former members of the same church denomination with the new member to be discipled. The shared common background could be a plus advantage. It is however a known fact that no two people will have exactly the same experience. It is a matter of making the best matches from the available information.

One other scenario is for converts who have many friends or relatives in the church. This is good and it makes their integration easier. In spite of this, it is still of absolute importance for the new believers to have one person they can look up to as their parent in the Lord. The church should do everything possible to prevent a situation where "everyone's responsibility becomes no one's responsibility."2 It was probably this fear that prompted Paul to urge the Corinthian believers to imitate him as their spiritual father (1 Cor 4:15-16). He did this fully aware that there were so many other faithful members.

\footnotetext{
${ }^{1}$ Sission, 174-175.

${ }^{2}$ Ibid., 175.
} 


\section{Gender Sensitivity}

The Holy Spirit works at will and may use a different gender to bring people of the opposite genders to Christ. Sometimes, it is a result of acquaintances at work or relationships that lead to marriages. This is acceptable and commendable. However, when it comes to the actual process of making a disciple, it is advisable to assign samegender mentors. It is probably with this line of thought that apostle Paul advised Timothy to teach the older men and women so they could in turn train the younger men and women (Titus 2:1-5). People of the same gender have similar basic felt needs. Thus, sensitivity to gender is an acknowledgment that people of the same gender can relate well because they have common needs. They are able to identify themselves with the other.

In cases where both a husband and wife are trained, they can work together as a team. Such couples can form a ministry team to assist new couples who join the church as husbands and wives. Under normal circumstances, the mentors will work individually with their gender-kind.

\section{Geographical Location}

People who live in the same geographical proximity have several advantages. They can work out a schedule to meet as often as they want. It is easier to keep appointments with the protege. If the disciple faces unforseen dilemma that needs some counsel, help is within reach. There is no travel cost involved. Communication is easier between the two. It is hoped that the two will form strong brotherly or sisterly bonds.

At the beginning of the mentoring process, spiritually newborn babies seem to have many questions and needs like their counterparts in the physical world. The need for guidance is high. During this time, the availability of the parent is crucial to the baby's 
health and survival. This being the case, it is recommended that a minimum of two meetings a week be set aside for nurturing the new disciple. The suggestion is for Wednesday and Friday. By meeting on these two days, it is one way of introducing the disciple to mid-week prayer meeting on Wednesdays and sundown vespers on Fridays. It will also help the mentor to know by Friday if the disciple will be in church on Sabbath. If the mentoree plans to be in church and fails, then a committed mentor makes a follow-up visit the same day. Sudden illnesses, unforseen developments, family or peer pressure have the potential to upset Sabbath plans of the new disciples.

The purpose of this visitation is not to condemn. It is purely a caring gesture and to pray with the person. During this visit, the mentor may share with the mentoree high points in the sermon or any faith-building lessons of benefit to the disciple. The mentor's role is to encourage the new disciple. All conversations ought to be positive, noble, truthful, or factual. A nearby mentor has a potential to build or destroy the mentoree who is acquainted with the mentor's character and reputation in the community.

\section{Record-Keeping}

Conservation of members calls for a good updated record-keeping of the new disciples. This is an activity that needs to be stressed. Management of their records is a sacred trust. Since discipling is not another activity of the church, the record-keeping will be done through the already existing church structures in Malawi.

The local churches in the cities are divided into smaller groups for the purpose of meeting in the homes for prayers during the week. Originally, the church appointed a group leader among the serving elders, deacons and/or deaconesses. called Later, the group added others in the leadership team. These leaders are the natural discipleship co- 
ordinators in their units. They know the people in their group. They can keep disciplemaking records of their group known as"Jesus Way."”

In the rural areas, there are usually a number of villages to a church. There will be one co-ordinator to a village. If the village is too large, it will be divided into small units of families, clan-zones, or whatever the church deems best and effective. The local church will keep the master record with names of those being discipled. The records will be simple but with necessary information regarding name, gender, age, place, mentor, date, and brief comments about visits and progress.

TABLE 2

SAMPLE RECORD-KEEPING

\begin{tabular}{|l|l|l|l|l|l|}
\hline Name & Gender & Age & Place/House \# & Mentor & Date/Comments \\
\hline & & & & & \\
\hline
\end{tabular}

Pastors and disciple-making co-ordinators will receive orientation on recordkeeping. Every church will have a hard-cover notebook for the records. Notebooks are easier to keep and are affordable even by the rural churches.

${ }^{1}$ Jesus Way groups meet in the homes of the members in the same area on a rotational basis for mid-week prayers on Wednesday and vespers on Friday and Sabbath evenings. These groups of between five and ten homes have been instrumental in winning new members and also nurturing the established Christians. They serve as small as house churches and are able to reach people where they are. There is a church appointed leader. The group elects a secretary and a treasurer. Some groups are more creative. They conduct revival meetings in the homes, hold evangelistic meetings within their territory or elsewhere. Some organize social gatherings for pot-lucks, retreats and games, raise funds for special church projects or some needy rural church. The pastor visits them. These groups have existing ideal disciple-making structures. 
These records will be helpful especially when a pastor or a mentor moves away. The successor will use the information to maintain continuity of the discipleship process. This will minimize the anxiety of the mentoree because the system addresses the common

The records will be audited by a team of auditors. The audit team will be comprised of the union and field discipleship co-ordinators, advanced leadership graduates, and all the union and the field departmental personnel. The pastors remain overall in-charge of the disciple-making strategy. The auditors will sign for their audit.

\section{Certification of the Participants}

People value anything obtained as a result of personal achievement. Certification of the participants is a motivational achievement factor. It attaches value and credibility to the training. It is hoped that these certificates will help to give some recognition as well as some degree of status elevation to the participants. The certificate will serve as a perpetual reminder of one's indebtedness and commitment to disciple-making. The union and field presidents and their disciple-making co-ordinators will be the signatories on the certificates. The involvement of these people as signatories is a statement about their seriousness and commitment to disciple-making.

To qualify for the certificate, successful candidates will be required to have a perfect class attendance which includes hands-on mentoring hours. There will be a provision for making up missed classes and activities. This might mean a delayed graduation if it is not possible to make up before the certification ceremony. Any incomplete assignments for more than nine months will be considered obsolete. The candidates will have to repeat the whole training within nine months.

The certification ceremony will also be an opportune time for consecration of all 
the participants. The program itself will include appropriate discipleship songs, message to challenge the candidates, response by the candidates, certificate awards, prayer of dedication, closing song, and benediction. The entire service is a public recognition of their call to disciple-making. It is intended to deepen the sense of their calling to the Gospel Commission. In addition, it will be a recruiting opportunity for new trainees. The graduation will be one way of advertising the discipleship ministry.

\section{Summary}

A strategy which does not produce the envisioned product is a futile exercise of a failed dream. It takes good planning and committed leadership to successfully implement discipleship strategy. Only then can it accomplish Christ's vision, discipling the nations.

Part of the planning covers education of the members in an effort to ensure the success of the disciple-making strategy. In this regard, the proposal has a built-in disciple education which aims at the spiritual growth of the Christian disciple makers. The Bible is the main source of their growth. The focus of the study is on the disciples: their call, role in the great Gospel Commission, spiritual gifts, impact of character, and the whole Christian lifestyle of a disciple.

Christ's leadership recruitment model made no room for volunteers. He either hand-picked them or they were recommended by the disciples. Good leaders display both ability and commitment. Such leaders are a result of a careful selection process in consultation with the local church. Timothy stands out as one such example who was recommended by the local churches at Lystra and Iconium. He turned out to be a committed and reliable worker in the gospel ministry. Involvement of the local church in disciple-making has a psychological benefit to the congregations in that they get some 
sense of ownership for the strategy. The members put more effort to make sure they succeed. This is possible partly because of the willingness on the part of the leaders.

At the same time, almost every congregation has people who have hidden leadership skills. Unless someone tries them, their skills will remain dormant. Wise leaders cast their leadership recruitment net deep enough to include such individuals. It takes prayer, discernment, encouragement, training, and continued support to develop such leaders. Like Moses with a youthful Joshua, they can be the most effective leaders in discciple-making ministry.

Discipleship is to be a watchword of every church congregation in Malawi. This can be achieved by sensitizing and training the administrators, pastors, and the laity in disciple-making. For effective results, the training is planned to take place in their respective locations. The studies will also include examination of various leadership styles and handling of personal issues as they apply to disciple-making. An advanced training will be conducted for smaller groups of ten lay persons at a time. The pastors and graduates from this training will be the trainers of the churches.

The rest of the members will be trained as primary mentors. They will be matched with new believers whom they will nurture to Christian maturity. Effective mentoring requires face-to-face meetings. Owing to lack of good and reliable transportation system in Malawi, the training and the matching will be restricted to the same geographical neighborhood. This will enable the mentors to meet in person with their mentorees regularly. At the same time, it will automatically eliminate transport costs for the two people. All these efforts are to make sure the strategy succeeds.

The matching exercise between mentors and the prospective mentorees can be 
tricky. Great care is needed to avoid unsuitable matches of the mentors and the initiate disciples. Mentors who work with people of the same gender and age group are more likely to develop quality relationship with the initiate. It facilitates honest and open communication between the mentor and the trainee. It also improves the quality of nurturing. As a result, the whole ministry stands to benefit.

The strategy includes assimilation of the new disciples into different ministries of the church according to their spiritual gifts. Their successful integration is a step further in the right direction. The final sign of their maturity is when they are able to lead another person to Christ. Then, they too are expected to nurture new individuals beyond baptism until the person becomes a discipler. The cycle continues and multiplies.

Undesirable as they are, lapses can be expected. They constitute a temporary experience. They could be short-lived if every effort is made to regain such individuals. This is one area where the mentor could ask for extra help. Lapses are to be treated like stumbles. They should be looked upon as a total failure.

A public certification ceremony witnessed by friends, family, and the entire church is an opportunity to highlight the importance of every member becoming a disciple maker. The most exciting success is realized when the candidates implement the training. The establishment of the souls in the truth and their growth in grace will be the reward of all those deeply committed to make disciples.

Radical disciple-making holds the key to the fastest spread of the gospel to all nations. It brings personal growth and spiritual maturity. It also increases the number of spiritually mature members. It is a factor in hastening the coming of God's kingdom. The reward of disciple-making is worth every effort. 
CHAPTER 6

\section{SUMMARY, CONCLUSIONS, AND RECOMMENDATIONS}

\section{Introduction}

This research has six chapters divided into four parts. The first part is the introduction. It is comprised of the first two chapters. The introduction presents the research concern, its biblical and theological basis, and the rationale for the whole study. It shows why the research is not a merely an academic exercise. It also serves as a leadership wake-up call to the real business of the church.

The second part is chapter three which provides anthropological and missiological reflections. This section makes a general investigation of the cultural practices of Malawians and their response to Christianity. The knowledge of Malawian traditional beliefs and cultural practices helps to develop a disciple-making teaching strategy that adequately addresses their deeper felt needs and suggests possible ministries.

The third section is comprised of chapters four and five. These two chapters present member-education as a solution to the problem of inactive Christians. It further advocates advanced training for the trainers.

This final chapter contains a general summary, conclusions, and recommendations. It contains recommendations for consideration and implementation by the leadership. It suggests possible nontraditional ministries for discipleship purposes. 


\section{Summary}

Chapter 1 is an introduction of the whole project. It presents the problem, task, justification of the project, definition of terms, limitations, dissertation overview, and the research methodology. It also puts in perspective the sole reason for creation of the church which is making disciples of all the nations (Matt 29:19-20).

Christ gave the Great Commission to His disciples whom He had trained to be the leaders of the church. They were commanded to teach, baptize, and mentor the new believers beyond baptism. The process of nurturing new believers until they attain spiritual maturity is what disciple-making is all about. Discipling new converts was the main feature and passion of the New Testament church. Unfortunately, it was lost somewhere along the way and the church has biblical reasons to reclaim it.

Disciple-making is a paradigm shift in which both the pastor and the laity become active role players. The main task of the pastors is to equip the lay persons. The trained laity has no excuse to continue as spectators. The training moves them from being mere fans to active participation in various ministries of the church. As a result of the paradigm shift, the church experiences both quantity and quality membership growth.

The Seventh-day Adventist Church is braced to recapture the lost passion of disciple-making. Various church publications and major business meetings like the 2005 General Conference Session in St. Louis, Missouri have been used to call the members back to biblical discipleship. Lately, the church seems to put much emphasis on discipleship. It is becoming more aggressive. The church in Malawi cannot afford to be indifferent and risk to be left behind in this revival.

The proposed disciple-making model in this paper is uniquely tailored to the 
Malawian church and is the main focus of the research. The interviews and the contribution from selected Malawian writers are meant to make the church well-informed as it re-addresses cultural practices. Recognizing the global nature of the mission of the church, the research has also examined, used, and adapted relevant materials from Western scholars. It is hoped that this usage has brought richness and depth to the project which has its foundation in the Scriptures.

Disciple-making is more than a traditional aspect of Malawian culture or an invention of the church aimed at increasing membership. The disciple-making strategy that has a Malawian focus in this paper is actually part of the biblical mission of the church. It is not restricted to a geographical area. It transcends man-made borders. It is a gigantic global missiological assignment to carry out the Great Commission to the ends of the world.

Chapter 2 examines discipleship models in the Bible. It traces the forms of discipleship in the Old Testament, the ancient Greek world, and during the time of Jesus and the apostles in the New Testament. Discipleship models are evident in the ministries of the Old Testament characters like Moses, Eli, Elijah, Elisha, and others. These people prepared their successors in a master-disciple relationship environment. In the New Testament, the Pharisees who claimed to be the disciples of Moses had their disciples too. John the Baptist had disciples who were part of his mission as Christ's forerunner. His disciples were later introduced to Jesus and became the first of the twelve of Christ's disciples. This type of master-disciple relationship was a common practice of the time when John the Baptist came on the scene.

Discipleship was also practised outside the Bible world. There were master- 
student relationships in the ancient secular world. In Latin, the word discipilus meant a learner, a student, a disciple, or an apprentice. The Greeks used the word mathetes to designate the same idea of teacher-student relationships. The philosophy gurus moved around with the disciples who learned and continued propagating their ideas.

When Jesus began His ministry, He introduced a different model of discipleship. His disciples were to learn not only from His mouth, but from His very way of life. They were to copy His character and contagiously duplicate it in more people. It was meant to be a revolution. Every future disciple was to be engaged in this strategy.

Jesus' very first disciples became effective recruiters of others even before they received training (John 1:35-51). After the invitation to see where and how Christ lived, the former disciples of John the Baptist were attracted by the life of the man they knew to be the Lamb of God (John 1:29). They decided not only to stay but to also invite others to join them. They wanted others to experience the joy of being with Christ. The response brought greater joy to the recruiters as well as the recruits who also stayed.

The disciples did not see themselves living happily away from Christ. At one time, many of Christ's followers were offended and drew back from following Him. In answer to Christ's question whether they also would leave Him, Peter said he and his fellow disciples would not to leave Him because they had found words of eternal life in Jesus (John 6:68). In other words, they had found salvation, which they needed and was worth their commitment. The three and a half years of learning from Jesus deepened their commitment. The disciples were prepared to suffer and to die for His cause. They were happy to continue as an extension of Christ's mission on earth.

Disciple-making is a systematic process of introducing people to Christ, teaching 
them by word and example to observe all things, and continuing to mentor them until they are able to reproduce their faith in others. The success of making disciples calls for a warm relationship between the student and the teacher. While the Holy Spirit is the power in the discipling process, yet people are attracted to Christian disciples characterized by genuine love, trust, truthfulness, openness, humility, and mutual respect. This honest life grows with prayer and deeper study of God's Word.

Paul and Silas are among the effective workers in the New Testament because they used Christ's discipleship strategy to raise up trusted leaders for the churches. Timothy, Titus, Mark, and Aquila and Priscilla were some of their fruits. Discipling needs patience. This is validated by the experience of Mark whose comeback is owed to Barnabas.

The duty and responsibility to train and raise the next generation of disciples rests with the contemporary clergy who provide leadership in today's churches. Paul, an experienced apostle in intentional discipling, recommends to Timothy to pass on to others what he had learned (2 Tim 2:2). Disciple-making is a legacy to be passed on.

The Holy Spirit gives to every born again Christian disciple a minimum of one spiritual gift to benefit the church in her mission to the world. The gifts are not for personal gain. They belong to the church in its mission to the world. The diversity of the gifts means more ministries working in perfect unity to produce productive disciplemaking Christians. The pastor can help to facilitate gift identification, provide quality training, and assign the new members to the right ministries according to their gifts. This gives them the thrill in the Gospel Commission.

Powerful testimonies are backed by completely transformed lives. There are 
certain cultural practices in every society that hinder and neutralize the power of the Christian disciples. There needs to be a corresponding agreement between the teachings and the daily life of the members in the community.

Chapter 3 looks at some anthropological and missiological reflections on discipleship. Anthropologically, the early Malawian inhabitants were Bantu, known for their hunting skills, fishing, and food-gathering. A number of the tribes were warriors. At the same time, the country was a slave trade route into the interior. People movements were common owing to several factors which included tribal wars.

David Livingstone is credited with his missiological concern for the people of Malawi. He saw slavery as an evil that needed to be stopped. His solution was to provide a dignified kind of trade and Christianity. Christ's gospel of love would also usher in civilization and destroy the slave trade.

David Livingstone appealed to the Scotland Christian missionary groups spearheaded by the universities. They responded favorably and came to introduce Christianity in Malawi. The early missionaries endured hardships leading to many deaths. Their unwavering commitment to mission and the gospel was in the end rewarded. The different mission groups, including the Adventists, opened schools to facilitate the spread of the gospel. As envisioned, the tribal wars and slave trade came to an end. Since then, education has proved to be an effective evangelization tool. Christian churches have added health and other social services mostly with the same view of preaching and making disciples. The churches have continued to be the agents of change in the society. In this way, they have lived to continue Livingstone's dream.

Christianity did not start in a vacuum. The people had some religious practices 
before. They knew and worshiped God in their own way. Way before being introduced to Christianity, they referred to God with no ordinary names. The names were suggestive of a belief in the existence of some supernatural Being. The people had much reverence for this supernatural Being. They felt unworthy and could not approach the unknown Being directly. They addressed and worshiped the Being through the spirits of their respected ancestors. The dual belief system in a Supreme Being and ancestral spirits proved to be hard for Christian missionaries to penetrate.

The dawn of Christianity meant a clash with some of these deep-rooted beliefs and practices. Some people accepted Christianity but privately continued in their traditional beliefs and questionable cultural practices. The practices went underground, thereby making it even harder to completely address. This is part of the task a Malawian tailored, disciple-making strategy has to accomplish.

This chapter is the basis for planning a disciple-making model for Malawi. The strategy has to be sensitive and yet biblically firm on the touchy ritualistic issues. Discipleship and entrance into God's kingdom demand total obedience to Christ's teachings (John 8:31; Heb 12:14). The truth is to be presented in such a way to make people feel loved. People must come to know and believe that the discipler is sympathetic with them. This conviction will make the battle against the suspected and questionable customs winnable.

It must be noted that there is nothing wrong with rites of passage, as such. The rituals are not necessarily evil in themselves. The problem lies in certain aspects surrounding the rituals. For example, in some cases, to complete a death ritual, the widow is required to have sex with a relative of the deceased husband. This is an outright 
evil practice that must end. The church could develop a special ministry to support the widows from this immoral ritual practice against them.

The replaced rituals can be used as bridges from traditional practices to the life of faith in the new community. The bridges will facilitate a smoother and more bearable transition to the new life. They will further help to get rid of a double Christian life. The spiritual bridges will give a unique character to the Malawian Christianity without any compromise of the truth. Finally, they will prevent the new disciples from unnecessary alienation from their families when they become Christians.

Chapter 4 considered practical steps for implementation of the strategy. It underscores the importance of adult-member education, modeling for the new believers, and leading them to growth through habits of deeper Bible study, prayer, and a consistent Christian lifestyle. The integration of the new members in various local church-based ministries and activities marks the completion of a disciple-making strategy.

Pastors hold the key to the success or failure of a disciple-making strategy. They are the teachers of their congregations. They set the pace and the direction for the members. Time spent in teaching the church members is an investment which sooner or later will yield results. But teaching is hard work because of the need for special motivational skills in dealing with adult learners. In addition, there is a high demand on the teachers to live a consistent Christian lifestyle. Spiritually mature disciples live what they teach.

As part of their education, the members are assigned responsibilities in proportion with their progress and ability. The hands-on experience takes away fear and provides inspiration to service. While education is an ongoing activity of the church, the members 
are to be fully equipped to match their assignment. At the time of their commission, it is a statement that the mentors are fully satisfied with their work and the person's response. It means that the graduates can be relied upon as an added number of qualified quality mentors. As models and mentors, they open even their private lives to those young in faith.

Well-prepared disciples are a result of a planned and a co-ordinated education system. The superiority of the strategy lies in regular monitoring checks. Honest disciple makers are willing to co-operate and be subjected to regular evaluation. This takes discipline and is a strong statement of maturity achievement. The suggested regular monitoring system is to make sure the ministries are operating efficiently as well as meeting the felt needs of the people.

Chapter 5 continues with the actual proposed teaching strategy, recruitment of the leaders for advanced training, and sensitizing the church leadership, pastors, and the selected church officers. The process is sensitive to compatibility of the mentor and the mentoree with reference to age, gender, and location.

Certification of the trained leaders marks the end of the first phase of leadership preparation but not the end of their disciple-making education. The ceremony empowers the trained leaders to humbly and confidentially take up their rightful positions in the mission of the church. The instituted follow-up training programs are to help maintain the quality of the disciple makers. These short training sessions create an opportunity for progress reports and encouragement of one another. They also become times for reevaluation of the training, prayers, rededication, and presentation of new challenges. In a way, these will be times of fellowship, renewal, and growth. 


\section{Conclusions}

The research on disciple-making for Malawi is important in that it helps the church to redefine its mission and reason for existence. This leads to re-examination of all its activities, leadership vision, and goals. It helps to chart the direction the leadership is to steer the church through. The insights from the traditional disciple-making models provide a basis for launching the proposed biblical-based strategy.

The Bible provides a solid foundation for making disciples. It renders its strong biblical and theological support for disciple-making. Discipling is a way of preparing a novice for greater responsibilities. Christ employed a discipleship model of teaching as an effective strategy for multiplying quality workers to spread the gospel to the whole world. The church can only justify its biblical existence today if it reclaims this lost passion and continues with God's business of disciple-making.

God's number one business is the salvation of His people. It was this concern that led to the call of Abraham (Gen 12) to leave his people and to dwell among non-Jewish nations. He was to share the knowledge of the one true God as he intentionally associated with his new neighbors. Christ had the same concern when He became "God with us" (Matt 1:21). He called and trained His disciples to address the same concern for the whole world.

Training is a more aggressive way for the contemporary disciple makers to accomplish the mission of the church. It makes the local church a disciple-making training center. This biblical method has a teaching ministry before and after the conversion experience which includes post baptism. It is a strategy to grow believers to real maturity where they reproduce their faith in others. 
Adult-member education is not merely a mental exercise. It seeks a complete change of the old life of sin. Changes are also expected in matters of dress, diet, and entertainment. Whatever is done must glorify God (1 Cor 10:31). To do otherwise is to deny Christ's Lordship. In fact, it becomes necessary to replace the old habits of $\sin$ as well as certain friends who may hinder the needed Christian growth and maturity (1 Cor $5: 9-11 ; 15: 33)$. The call to discipleship is also a call for a holistic change that denies self rule (Luke 9:23).

Although the church in Malawi is located in an economically challenging section of the world, it can still be a leader in disciple-making. This biblical strategy can be successful in any place where the people follow Christ's way of discipling. The challenge lies in the degree with which the leadership and the membership of the church obey the demands of the Gospel Commission.

The challenge of questionable unchristian ritual practices remains to this day. Occasionally, the customs re-surface among the church members in connection with initiation, death, and funeral rites. When this happens, they neutralize the power of the gospel. This points out the need for a continued disciple-making teaching ministry which should be tailored to the Malawian culture.

Tackling these issues calls for an openness to discuss and critically investigate the hidden aspects of the rituals. The more positive way is to introduce alternative Christian rituals. In this regard, an ongoing open dialogue with the deep-rooted traditions and the cultural ritualistic practices would be most ideal. It would encourage creation of an authentic Christianity with a Malawian and yet global face. Ultimately, this will boost the sense of ownership among the church members in Malawi. 
The leadership at every level of the church has a big part to play in Malawi's disciple-making strategy. If the leaders keep their enthusiasm, oneness, and a hardworking spirit, the strategy will realize its goals. It will enhance the quality of individual spirituality and multiply the number of active disciple makers. It is important for the leaders to keep their focus on the big picture of the Gospel Commission. They will need to be open-minded and courageous enough to venture into nontraditional ministries.

Radical disciple-making should be the intentional lifestyle of every church. This means to maximize utilization of all the spiritual gifts represented in the church without regard to gender. This may also mean to strategically relocate to unentered pockets found in some parts of Malawi for a single purpose of making disciples. People must put the interests of the Gospel Commission first. This is the way to bring revolution, life, and purpose in the churches.

\section{Recommendations}

The following recommendations seem valid for members and churches of the Malawi Union. However, individuals and churches will no doubt have valid additions.

1. Spiritual Leadership. The leaders are to set a spiritual tone and pace for the members. This whole strategy is Bible-based and its appeal must come from the same source. Methods may change and differ, but biblical principles are to be adhered to. As already pointed out, character is a big factor in discipleship. There is no substitute for a transformed character. It is the Christ-like character that attracts people.

2. A Logo. Leadership can be creative and come up with something for the people to visualize. This could be a watchword or a wall picture of Jesus leading the lambs to green pasture. It must be something the people can relate to and easily grasp. 
One powerful picture to impress Malawians could be an adult holding the hands of a baby learning to walk. The caption could read: "Spiritual babies need help, too." The message would be powerful.

3. Training. It should be remembered that the strategy aims at achieving both quantity and quality. The administration should endeavor to maintain high standards. It means tracking all the results with real interest. This is not a ministry to use remote controllers. The leaders can visit and spend some hours or a night with the people at the training centers. It will boost morale. The people will attach more value to the training if they see their office administrators coming to join them.

4. Spiritual Gift-Discovery. If an average church member in Malawi was asked to mention several spiritual gifts, probably many will mention only one. Singing is the well-known spiritual gift people seem to know about. The administrators would do well to plan spiritual gift discovery seminars. It will widen the peoples' world of gifts.

5. Spiritual Gifts in Women. Women are fellow and equal participants in disciple-making. They need to function freely in their gift-oriented ministries. It is incumbent on the leaders to protect them from those who resist their active participation in certain activities of the church. Both genders have been given spiritual gifts to be used in building God's kingdom through disciple-making.

6. HIV/AIDS Ministry. The church is part of a community that is suffering from the HIV/AIDS epidemic. Although statistics are hard to find about the members the church is losing to AIDS, yet people know that there has been loses. Both workers and lay persons are lost to HIV/AIDS related diseases. Some of the members baptized are already infected by the virus at the time they join the church. It is in the highest interest 
of the church to have a specialized ministry for this group of people. There are single parents and orphans left behind. Given the Malawian complex kinship system, it is realistic to say that every person in the church has been touched by this epidermic.

7. Grief Ministry. This ministry can do more than it is traditionally known in the church. The church in Malawi can defend the rights of widows and children of the deceased husbands and fathers. In most cases, the traditional practice has favored the relatives of the deceased male spouse to inherit his estate. In worst scenarios, the widow is left to struggle with the children whose possible support was taken by the family of the late husband. There have been activists and the government has enacted a law to discourage this practice. It will be awhile before it is respected in every corner of the country.

The church can play a simple role of seeing that the law is enforced for those vulnerable women and children. One way is to encourage making wills which has not been the tradition. This will be a good ministry for the church. It meets a real felt need.

8. Ministry to Single Parents. Culture is changing rapidly. Some of the traditional structures that kept marriages intact have crumbled down. Those that are left, have been greatly restructured. There are several factors which have contributed to more single parents today than the society used to have. A ministry to disciple one-parent households would meet a real felt need of the Malawian communities. It will no doubt make a direct contribution to discipleship strategy.

9. Young Adults Ministry. Malawi has single or married young adults who do not quite fit into the Adventist Youth activities. This is probably the age group that is also more open to the gospel and is willing to change. The church can develop a special 
holistic nurturing ministry to grow these young adults to maturity. They need lots of guidance due to their age as well as the fact that a good number may have non-Adventist backgrounds. An aggressive discipling strategy will help them and at the same time strengthen the church in Malawi.

10. Financial Commitment. Although everything will be done to avoid expenses, yet there will be unavoidable expenditures. The training seminars will require supplies. It is therefore advisable that every local church and administrative office make a yearly budget allocation for disciple-making.

11. A Discipleship Day of Fasting. Disciple-making needs a big bang so that every church member in Malawi knows about it. Declaring fasting one Sabbath day would be a strong statement about the seriousness of the leadership towards disciplemaking. The day would be spent in serious prayer and heart-searching so that the Holy Spirit could unction the strategy. If properly planned and communicated, it could be the biggest signal the church could make in recent years. Some of the old members would be reminded of those days when every GC Session was marked by a day of fasting.

This disciple-making strategy proposed for the church in Malawi has been made as a practical guide. It could be implemented as it is or with some changes owing to the various factors unique to each situation. At the same time, it would not work with the same envisioned success if the principles which Christ used for disciplig His twelve original men are not followed. The proposal has certain cardinal points to be taken as they are. These include but are not limited to the role of Bible study, prayer, warm relationships, non-judgmental attitudes toward the novices, patience, and a consistent Christian lifestyle. These elements are essential to a successful discipling process. 
Disciple-making portrays the true image of the church as a living organism. Every pastor and every church member contribute to the growth of the living body of Christ. A disciple-making church becomes the agent of God's love through which the Lord reaches and transforms sinners. Disciple-making keeps the church on the right path to reach the whole world with Christ's good news of salvation and His second coming. Jesus promised His abiding presence in the church as a response to the service of His obedient contemporary disciple-makers. Christ further promised to pour out the Holy Spirit for the finishing of the Gospel Commission through His church. When the church engages itself in disciple-making, it uplifts and glorifies Christ so that His death on the cross is not in vain. The disciple-making churches are gatherers of many who in the words of Christ, "will come from the east and the west, and will take their places at the feast with Abraham, Isaac and Jacob in the kingdom of heaven (Matt 8:11). 
APPENDIX A

FIVE SHORT TOPICAL SERMONS 


\title{
Appendix A
}

\section{Five Short Topical Sermons}

\author{
SERMON 1 \\ GOD'S WORD \\ Mau A Mulungu
}

Introduction: The Bible is God's Word. It was written with the help of the Holy Spirit by the prophets and other holy people. Therefore, it is God's letter containing prophecies and promises to the lost mankind. It is the source of wisdom, guidance, peace, and comfort in times of grief and sorrow. The Bible is reliable. It shapes and builds character. The Scriptures reveal God's character, show the way to Christ and salvation.

1. God used holy people to write His words.
a. The Holy Spirit was the Agent (2 Pet 1:21).
b. The Bible is God's inspired Word (2 Tim 3:16).
c. The writers were given God's words ( Jer 1:9; Ezek 3:17).

2. The Bible testifies about Christ.

a. The Scriptures testify of Jesus Christ (John 5:39).

b. The Old Testament prophesied concerning Him (Luke 24:27, 44).

3. The Bible was written and preserved for our benefit.
a. The present generation learns from the past (Rom 15:4; 1 Cor 10:11).
b. Helps in character building (Pss 119:9-11; John 17:17).
c. The Bible is like a lamp to show the way in darkness (Pss 119:105).

4. The Bible is only helpful if read and obeyed.

a. The Holy Spirit helps with understanding of the Bible ( 1 Cor 2:11-14).

b. Study with humility and willingness to obey God.

c. The Bible should interpret itself with other passages (Isa 28:9-10).

d. God's Word heals and delivers (Pss 107:20).

Appeal for faith in God's Word and commitment to read it daily for spiritual strength and growth. Conclude with an illustration of a young lady who bought a book, shelved it as an uninteresting book but came back to it after meeting the author who became her fiance. She then read it in one sitting with smiles and audible laughter. The difference was in knowing and falling in love with the author. It is the same with the Bible. "When your words came, I ate them; they were my joy and my heart's delight, for I bear your name, O Lord God Almighty" (Jer 15:16). 


\section{SERMON 2}

\section{GOD'S CALL TO DISCIPLESHIP \\ Mulungu Aitanira Aphunzi Ku Utumiki}

Introduction: God calls His children to be co-workers with Him in a life of service. The great work of salvation needs all to be active participants. Christ trained His twelve original disciples and commanded them to multiply the results by making other disciples in a similar way.

Discipleship ministry nurtures new believers to full spiritual maturity. It increases membership in the church. It is Christ's divine way of reaching the nations of the world with the gospel. Effective disciples are those with a genuine conversion experience.

1. God's call is not an accidental event.

a. God has a purpose for every person born in this world.

b. His call precedes birth (Jer 1:5).

c. Paul was chosen for a specific mission to the Gentiles (Acts 9:15).

d. A disciple is a learner who develops into a teacher.

2. Jesus calls every believer to a life of service as a disciple.

a. The disciples are fishers of men and women (Matt 4:19).

b. There is great need for more workers (Matt 9:37-38).

c. Time is running out (John 9:4).

d. Jesus' disciples have the gigantic task of reaching the world (Matt 28:18-20).

3. Genuine conversion is required of every disciple.

a. There is danger in the form of godliness ( 2 Tim 3:5).

b. Jesus denounced hypocrisy among the leaders (Matt 23).

c. Hypocrites shut kingdom doors for themselves and others (Matt 23:13-15).

d. Conversion is power in the work of a disciple (Luke 22:31-32).

e. Converted Christians honor commitments and pledges (Num 30:2; Eccl 5:1-5).

f. Avoids evil in any form including unchristian ritual practices (Deut 18:9-13).

4. God is responsible for the harvest.

a. There will be a harvest if people do their part (Pss 126:6).

b. God makes the sown seed grow (1 Cor 3:6-8).

c. Disciples are Christ's ambassadors reconciling the world to God (1 Cor 5:20).

Appeal for real conversion of every disciple present and renewed commitment to fulfill Christ's Great Commission to the world. This is the mission of the church which exists for service to the world. "Therefore, I urge you, brothers, in view of God's mercy, to offer your bodies as living sacrifices, holy and pleasing to God-this is your spiritual act of worship. Do not conform any longer to the pattern of this world, but be transformed by the renewing of your mind. Then you will be able to test and approve what God's will is-his good, pleasing and perfect will" (Rom 12:1-2). 


\section{SERMON 3}

\section{GOD'S GRACE \\ Chisomo cha Mulungu}

Introduction: Sinners turned into disciples is nothing but God's mercy. Nobody deserves this trust. Salvation is a story of God's wonderful and amazing grace for the sinner. Grace is God's mercy given to save the sinner from the power of sin and death. Disciples are an extension of Christ's ministry to save sinners and give them hope of eternal life.

1. God's gift of grace to mankind.

a. Sin left all humanity miserable and without hope (Rom 5:12).

b. Jesus came down not to condemn but to save (John 3:17; Rom 5:19)

c. This love for the rebellious humanity is inconceivable (Rom 5:8).

d. It is a gift to be received by faith in what Christ has done (John 3:16).

2. God's grace is for everybody (Titus 2:11-12).

a. It brings salvation to all humanity.

b. It is overwhelming and the receiver's response is surrender to Christ.

c. It has cleansing power even for the present generation.

3. Grace is God's gift and cannot be earned.

a. A sinner needs faith to receive this gift (Eph 2:8-9).

b. Grace upholds the law in appreciation of Christ's gift (Rom 6;1-2,15).

c. Jews, Gentiles, male, and female are all saved by God's grace (Acts 15:11).

d. A sinner can choose to reject it but to his or her own eternal loss ((John 3:16).

4. God's grace transforms and recreates a life over again.

a. God pours out more grace where sin increases (Rom 5:20).

b. Grace transforms and recreates sinners to do Christ's good works (Eph 2:10). c. Recipients of God's grace become new creatures in Christ (2 Cor 5:17).

d. Disciples should grow in grace and knowledge of the Lord (2 Pet 3:18).

Appeal for full acceptance of God's grace enables the disciples in their battle against sin. They become victorious in Christ Jesus. "God is able to make all grace abound to you, so that in all things at all times, having all that you need, you will abound in every good work" (2 Cor 9:8). 


\section{SERMON 4}

\section{GOD'S SPIRITUAL GIFTS \\ Mphatso za Mzimu}

Introduction: Believers are given various spiritual gifts by the Holy Spirit to enable them serve in different ministries to enhance the mission of the church. The disciples are inter-dependent on one another because no one person has all the gifts needed by the church. It is therefore, important to heed Christ's call for unity in diversity. These gifts enrich the church. Education and co-ordinated mobilization will yield maximum benefits.

1. What are spiritual gifts?

a. They are "divine abilities distributed by the Holy Spirit to every believer according to God's design and grace for the common good of the body of Christ" (Bruce Bugbee, What You Do Best in the Body of Christ, 38).

b. There is a difference between spiritual gifts and the fruit of the Holy Spirit.

c. Spiritual gifts are action "doing" qualities while the fruit of the Spirit (Gal 5:22-26) are "being" qualities (Ibid., 54).

d. Natural gifts are indicators of spiritual gifts that God gives those who experience a spiritual birth (Ibid., 52).

2. Spiritual gifts are for the purpose of unselfish service through the church.

a. The church exists for God's mission of making disciples (Matt 28:19-20).

b. The gifts are not intended for personal use.

c. There is need for education regarding the gifts (1 Cor 12:1).

d. The Holy Spirit, Godhead member was involved at creation (Gen 1:2, 26).

e. Every believing disciple has been given a gift to ably serve others (1 Pet 4:10).

3. Spiritual gifts dispensation and discovery.

a. The Holy Spirit dispensed spiritual gifts for building the church (Eph 4:7-13).

b. There are variety and degrees of the spiritual gifts (Rom 12:6-8; 1 Cor 12:4-11).

c. No gift is more important than the other just as body organs (1 Cor 12:14-26).

d. Discovery calls for prayer, study, trials, affirmations from others.

e. Discovery and use help in fulfilling God's purpose in life.

4. God increases capacity of those who use their gifts.

a. A gift-based discipleship translates into doing what people enjoy to do for God.

b. Undeveloped gifts are lost together with the owners (Matt 25:24-30).

c. Some gifts are acquired as God sees the need as at Pentecost (Acts 2).

d. God has need for every gift for advancement of His mission on earth.

Appeal for prayers, serious study, and willingness to discover God-given gifts in our lives and use them to His glory in various ministries of the church. Do not neglect your gift (1Tim 4:14). Remember to always fan into flame your God-given gift (2Tim:1:6). "Night is coming, when no one can work" (John 9:4). 


\section{SERMON 5}

\section{GOD'S PROMISES FOR VICTORY \\ Chigonjetso Mu Malonjezo A Mulungu}

Introduction: Discipleship is a calling that puts people on the path of many fiery trials of their faith and trust in God. Jesus who has walked this way promises to give victory to His followers over sin and temptation. It is through these trials that the faith of the disciples is perfected. The devil who accuses and afflicts is silenced when faith triumphs. God's people need to be obedient to God's requirements and claim His promises.

1. Victory is God's power + person's will to overcome Satan and sin.

a. Jesus gives power to those who enter discipleship life (John 1:12-13).

b. The Holy Spirit sanctifies disciples to grow spiritually (2 Thess 2:13).

c Strong relationship with Jesus is critical to a victorious life.

d. There is need to overcome sinful thoughts and deeds (1 Thess 4:3-7; Jas 4:7-8).

2. Fear is an enemy to discipleship.

a. Misplaced fear intimidates, paralyzes, and brings defeat.

b. Fear of people and magic has chained disciples to heathen practices.

c. The Lord has not given disciples the spirit of fear (2 Tim 1:7).

d. Disciples should fear God not people or magic (Pss 118:7-9; Luke 12:4-5).

3. Fiery trials are part of experience by Christians.

a. Jesus has walked the way before us (John 16:33; 1 Pet 2:21).

b. The way of heaven is not always smooth (Acts 14:22; 1 Pet 4:12-13).

c. Jesus knows our faith and has way of escape for us (1 Cor 10:13; Pss 34:17).

d. Job knew Jesus by experience and endured sufferings (Job 19:25-27).

e. There is power in prayer.

4. Assurance and reward of victory in Jesus.

a. Unwavering faith will always win battles of this life (1 John 5:4-5).

b. Personal experience and testimony have power to overcome devil (Rev 12:11).

c. Faithful disciples will judge and rule with Christ ( Rev 2:26-27).

d. The disciples who overcome shall inherit eternal life $(\operatorname{Rev} 21: 7)$.

Appeal for unshakable faith and trust in God and in His promises. He has been faithful to us and we have no reason to doubt Him. Christ has already conquered the devil who goes about as a roaring lion. Our security is assured if we cling to Jesus no matter what happens because we do not move by sight but faith. "I have set the Lord always before me. Because he is at my right hand, I will not be shaken (Pss 16:8). 
APPENDIX B

APPLICATION FOR CONFERENCE STATUS SURVEY TEAM (MU ACTIONS 1239-1240/308/DECEMBER 3, 2003) 
VOTED; $\omega$ accept a recommendation from South Malawi Ficld an application for a Conference Status to the Southern Africa Indian Oecan I)ivision to scnd a survey team for a cimference Status at South Malawi Ficld.

VOTED: to accept a rocnmmendation from Central Malawi licld an application for a Conference Status to the Southern Africa Indian Ocean Division to send a survcy team for a Conference Status at Cenural Malawi Field.

VOTED: to rocommend the name of Mrs $\Lambda$ Kachiwala of Malamuln Collcge of Health Scicnces for Southern $\Lambda$ frica-Indian Ocean Division Bursary Programme to study Nursing in South Africa with effect from February 3, 2004.

VOTED: to accept the Iental equipment donation from the United Stales of America for North Malawi Field to empower to open a Dental Clinic.

VOTED: to pass on a scrvicc call to $\mathrm{Mr}$ and Mrs S II Kabambe of Matandani Training School Iunjika Scondary School as Teachers cffective January 1, 2004.

VOTED: to pass on the following strvice request

Dr Tommy Nkungula I:ducation D ircetor Southern Africs Indian Deean Division to Malawi Innion to evaluate Sccondary and Colleges in July - August 2004.

VOTED: to adopt the General Confurcuce Session, 2005 on Profiling Adventist Leadership as presented.

VOTED: to adopt the General Conference Scssion, 2005 on lime of Spiritual limphasis as presented.

VOTED: to adopt the Seventh-day Adventist Cuidelines for Fmployer and Iimplivere relationships as prosentud.

VOTED: to accent and pass on to liield Presidents $t)$ discuss with the community on closing of AIS Clinics and pass the findings to MU for final decisiom.

VOTED: 10 accept the progress report on Lakcview Campus and recommendation to open as Campus of Malawi Adventist College in January 2004.
SOUTH MALAWI FIELD CONFFIRFNCF STATUS 1239

CFNTRAL MALAWI FIELI) CONPERENCK STATUS 1240

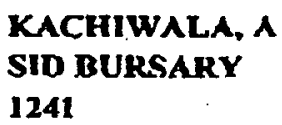

DENTAL FQUIPMENT DONATION

1242

KABAMBF, S \& H SFRVICI CALL 1243

NKUNCULA, T SFRVICF, RFQUEST 1244

ADVTNTIST LEADFRSHIP 1245

SPIRITUAL EMPHASIS

1246

PMPLOYER \& FMPLOYEE RELATIONSIII"

1247

CLOSING; OF A H S CLINICS 1248

LAKFVIEW PROGRESS 1249

December 3, 2003 
VOTED: to adopt the recommendation from Ciencral Cinnlerence Conmission om higher I:ducation report.

Dr S K Mfune

S K Mrune:

B D Chilunga:
HIGHFR FIUUCATION

1251

LAST PRAYER

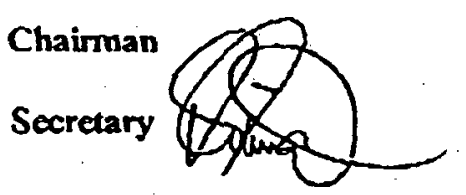

Mtisunge Namalima: Recording Secretary

[226]

MUM YEAR-END COMM

309

December 3, 2003 


\section{SELECTED BIBLIOGRAPHY}

Aaseng, Rolf E. Reflections in a Mission Mirror: Ancient Wisdom from Younger Churches. Minneapolis, MN: Kirk House Publishers, 1998.

Aberly, John. An Outline of Missions. Philadelphia, PA: Muhlenberg Press, 1945.

Adair, John. The Leadership of Jesus and Its Legacy Today. Cleveland, $\mathrm{OH}$ : The Pilgrim Press, 2002.

Adna, Jostein, and Hans Kvalbein, eds. The Mission of the Early Church to Jews and Gentiles. Tubingen, Germany: Mohr Siebeck, 2000.

Adsit, Christopher B. Personal Disciple-Making. Nashville, TN: Thomas Nelson Publishers, 1993, 83. Quoted in Andy and Kim Harrison, The Discipling Cycle Series: Seek, Share, Serve, 166. Nashville, TN: LifeWay Press, 2002.

Arn, Win, and Charles Arn. The Master's Plan for Making Disciples. Grand Rapids, MI: Baker Books, 1998.

Baker Encyclopedia of the Bible. 1995 ed. S.v. "Disciple."

Barger, Rick. A New and Right Spirit: Creating an Authentic Church in a Consumer Culture. Herndon, VA: The Alban Institute, 2005.

Barnett, Jake. Wealth and Wisdom. Colorado Springs, CO: NavPress, 1987.

Biehl, Bobb. Mentoring: Confidence in Finding and Becoming One. Nashville, TN: Broadman \& Holman Publishers, 1996.

Blatherwick, Douglas P. A Layman Speaks. London, Great Britain: The Epworth Press, 1959.

Bloede, Louise W. The Effective Pastor: A Guide to Successful Ministry. Minneapolis, MN: Fortress Press, 1996.

Bosch, David J. Transforming Mission: Paradigm Shifts in Theology of Mission. Maryknoll, NY: Orbis Books, 1996. 
Booth, Joseph. "The Call for the Message in Central Africa." The Advent Review and Sabbath Herald, May 13, 1902, 12.

. "British Central Africa." The Advent Review and Sabbath Herald, December $23,1902,17$.

Bowen, Roger. So Send I You: A Study Guide to Mission. London, Great Britain: SPCK, 1998.

Branch, Mabel. "Our Nyasaland School." The Advent Review and Sabbath Herald, April $6,1905,13$.

Branch, Thomas. "A Word from Nyassaland." The Advent Review and Sabbath Herald, April 27, 1905, 13.

Branch, Thomas, Mrs. "British Central Africa." The Advent Review and Sabbath Herald, November 18, 1902, 17.

. "In the Land of Livingstone." The Advent Review and Sabbath Herald, August $3,1905,17$.

Brodie, Thomas L. The Crucial Bridge: The Elijah-Elisha Narrative as an Interpretive of Genesis-Kings and a Literary Model for the Gospels. Collegeville, MN: The Liturgical Press, 2000.

Brown, Lesley, ed. "Religion." New Shorter Oxford English Dictionary. 2 vols. Oxford: Clerendon Press, 1993.

Brown, Victor R. Disciple Ministry: Integrating New Members into Church Fellowship, 1993 (?). Photocopy. Lakeview Seminary, Ntcheu, Malawi.

Bruce, Alexander Balmain. The Training of the Twelve Or Passages Out of the Gospels: Exhibiting the Twelve Disciples of Jesus Under Discipline for the Apostleship. Grand Rapids, MI: Zondervan Publishing House, 1963.

Bugbee, Bruce. What You Do Best in the Body of Christ. Grand Rapids, MI: Zondervan, 2005.

Burkett, Larry. The Word on Finances: Topical Scriptures and Commentary. Chicago, IL: Moody Press, 1994.

Burrill, Russell. Radical Disciples for Revolutionary Churches. Fallbrook, CA: Hart Research Center, 1996.

Callen, Barry L. Authentic Spirituality: Moving Beyond Mere Religion. Grand Rapids, MI: Baker Academic, 2001. 
Cho, Paul Y. Prayer: Key to Revival. Dallas, TX: Word Publishing, 1984.

Coates, Ken S. A Global History of Indigenous Peoples: Struggle and Survival. Houndmilla, Great Britain: Palgrave MacMillan, 2004.

Coleman, Robert E. The Master Plan of Evangelism. Westwood, NJ: Fleming H. Revell, 1964.

. The Master's Way of Personal Evangelism. Wheaton, IL: Crossway Books, 1997.

Collinson, Sylvia. Making Disciples. Carlisle, UK: Paternoster Publishing, 2004.

Crosby, Cynthia A. Historical Dictionary of Malawi. Metuchen, NJ: The Scarecrow Press Inc. 1980.

Crown Financial Ministries. Biblical Financial Study: Small Groups Student Manual. Gainesville, GA: Crown Financial Ministries, Inc., 2003.

Dawson, Christopher. The Historic Reality of Christian Culture: A Way to the Renewal of Human Life. London, Great Britain: Routledge and Kegan Paul Ltd., 1961.

Debenham, Frank. Nyasaland: The Land of the Lake. London, Great Britain: Her Majesty's Stationery Office, 1955.

Dowsett, Rose. The Great Commission. Grand Rapids, MI: Kregel Publications, 2001.

Dyet, James T. Getting Through to Adults: Survival and Success in the Adult Classroom, Denver, CO: Accent Books, 1980.

Eastwood, Cyril. The Priesthood of All Believers: An Examination of the Doctrine from the Reformation to the Present Day. Minneapolis, MN: Augsburg Publishing, 1962.

Easum, Bill. Unfreezing Moves: Following Jesus into the Mission Field. Nashville, TN: Abingdon Press, 2001.

Elliston, Edgar J. Home Grown Leaders. Pasadena, CA: William Carey Library, 1992.

Elmslie, W. A. Among the Wild Ngoni. London, Great Britain: Frank Cass \& Co., Ltd., 1970.

Encyclopedic Dictionary of Religion. 1979 ed. S.v. "Disciple." 
Estrada, Nelson P. From Followers to Leaders: The Apostles in the Ritual of Status Transformation in Acts 1-2. London, Great Britain: T \& T Clark International, 2004.

Exman, Gary W. Beyond the Numbers Game. Lima, OH: Fairway Press, 1997.

Finley, Mark. "Challenges to Missions." Quoted in Ninth Business Meeting of the $58^{\text {th }}$ General Conference Session of Adventists, Adventist Review, July 8, 2005, 20.

Ford, Paul R. Unleash Your Church: A Comprehensive Strategy to Help People Discover and Use their Spiritual Gifts. St. Charles, IL: ChurchSmart Resources, 2002.

Fray, Harold R., Jr. Conflict and Change in the Church. Boston, MA: Pilgrim Press, 1969.

Gangel, Kenneth O., and James C. Wilhoit, eds. The Christian Educator's Handbook on Adult Education. Wheaton, IL: Victor Books, 1993.

Gelfund, Michael. Shona Ritual. Cape Town, South Africa: Juta \& Co., Limited, 1959.

General Conference of Seventh-day Adventists. Seventh-day Adventist Believe: A Biblical Exposition of 27 Fundamental Doctrines. Hagerstown, MD: Review and Herald Publishing Association, 1988.

. Seventh-day Adventist Minister's Handbook: Silver Spring, MD: Ministerial Association, 1997.

. Seventh-day Adventist Yearbook. Hagerstown, MD: Review and Herald Publishing Association, 2005.

. Witnessing for Christ. Washington, DC: Review and Herald Publishing Association, 1981.

.Working Policy. Washington DC: Review and Herald Publishing Association, 2004-2005.

Getz, Gene A. The Walk: Growing into the Fullness of Christ. Nashville, TN: Broadman \& Holman Publishers, 2000.

Gnanakan, Chris. "Mentoring: The Way to Build God's Kingdom." Church Growth Digest, Summer 2000, 17.

Gray, Richard. Black Christians and White Missionaries. Great Britain: Bell and Bain, Ltd., 1990. 
Green, Joel, and Max Turner, eds. Jesus of Nazareth: Lord and Christ. Grand Rapids, MI: William B. Eerdmans Publishing Company, 1994.

Greenleaf, Robert K. Servant Leadership: A Journey into the Nature of Legitimate Power and Greatness. Mahwah, NJ: Paulist Press, 1991.

Grisanti, Michael A. "Israel's Mission to the Nations in Isaiah 40-55: An Update." The Master's Seminary Journal 9 (Spring 1998): 39-61.

Groome, Thomas H. Sharing Faith: A Comprehensive Approach to Religious Education and Pastoral Ministry. New York, NY: HarperCollins Publishers, 1991.

Grys, John, and Greg Schaller. "Growing a Healthy Church.” Ministry, March 2001, 1113.

Gushee, David P. "Our Missing Moral Compass." Christianity Today, November 2005, 88.

Haloviak, Bert. "Archives and Statistics." Quoted in Second Business Meeting of the $58^{\text {th }}$ General Conference Session of Adventists. Adventist Review, July 4, 2005, 28-30.

Hardesty, Nancy. "Gifts," The Other Side. July-August 1977, 40. Quoted in C. Peter Wagner, Your Spiritual Gifts Can Help Your Church Grow, 41. Ventura, CA: Regal Books, 1979.

Hendry, Joy. Other People's Worlds: An Introduction to Cultural and Social Anthropology. New York, NY: New York University Press, 1999.

Hiebert, Paul G., R. Daniel, and Tite Tienou. Understanding Folk Religion: A Christian Response to Popular Beliefs and Practices. Grand Rapids, MI: Baker Books, 1999.

Hok, Gosta. "Luther's Doctrine of Ministry." Scottish Journal 7 (March 1954): 16-40.

Howe, Leroy. A Pastor in Every Pew: Equipping Laity for Pastoral Care. Valley Forge, PA: Judson Press, 2000.

Hughes, Selwyn. The Introvert's Guide to Spontaneous Witnessing. Minneapolis, MN: Bethany House Publishers, 1983.

Hull, Bill. The Disciple Making Pastor. Old Tappan, NJ: Fleming H. Revell, 1988.

Hunt, Bob. "Training for God's Mission-An Historical Overview." Church Growth Digest 20 (Autumn 1998): 8-9. 
Hutchison, Russell S. "A Study of the Christian Education of Adults in Relation to the Needs and Values of Adults in Selected Protestant Churches in Muskingum County, Ohio." Ph.D. diss., University of Pittsburgh, 1962.

Issler, Klaus. Wasting Time With God: A Christian Spirituality of Friendship With God. Downers Grove, IL: InterVarsity Press, 2001.

James, George. "In the African Interior." The Advent Review and Sabbath Herald, August $1,1893,485$. 502 .

. "In the Interior." The Advent Review and Sabbath Herald, August 8, 1893, . "In the Interior." The Advent Review and Sabbath Herald, August 15, 1893, 518.

Johnston, James. Robert Laws of Livingstonia. London, Great Britain: Pickering \& Inglis, 1935 (?).

Jones, Wayne R. Using Spiritual Gifts. Nashville, TN: Broadman Press, 1985.

Kenyatta, Jomo. Facing Mt. Kenya: The Tribal Life of the Gikuyu. New York, NY: Vintage Books, 1962.

Kerckhoff, Allan C. Socialization and Social Class. Englewood Cliffs, NJ: Prentice-Hall Inc., 1972.

Killinger, John. Fundamentals of Preaching. Philadelphia, PA: Fortress Press, 1985.

Kincaid, Ronald Warren. A Celebration of Disciple-Making. Wheaton, IL: Victor Books, 1990.

. "The Missing Ingredient in Christian Maturity: A Call to Church-Centered Evangelism." D.Min. diss., Fuller Theological Seminary, 1989.

Kittel, Gerhard. "Mathetes." Theological Dictionary of the New Testament. 10 Vols. Translated by Geoffrey Bromiley. Grand Rapids, MI: Eerdmans, 1967. 4:441.

Knight, George R. "Knight's Law Applied to Church Leadership." Ministry, July-August, 2005, 24-28.

Knowles, George E. How to Help Your Church Grow. Washington, DC: Review and Herald Publishing Association, 1981.

Kottak, Conrad Phillip. Cultural Anthropology, $8^{\text {th }}$ ed. Boston, MA: McGraw-Hill, 2000. 
Land, Gary. Historical Dictionary of Seventh-day Adventists. Lanham, MD: Scarecrow Press, 2005.

Larkin, William J., Jr., and Joel F. Williams, eds. Mission in the New Testament. Maryknoll, NY: Orbis Books, 2003.

Latourette, Kenneth S. Missions Tomorrow. New York, NY: Harper \& Brothers Publishers, 1936.

Linden, Ian, and Jane Linden. Catholics, Peasants, and Chewa Resistance in Nyasaland 1889-1939. Berkeley, CA: University of California Press, 1974.

Lindgren, Alvin L., and Norman Schwarz. Let My People Go: Empowering Laity for Ministry. Nashville, TN: Abingdon, 1990.

Lisilira, Liness, resident of Chimwankhunda Township, Blantyre. Telephone interview by author, 15 January 2006, Blantyre, Malawi.

Lisilira, Martin, retired carpenter of Chimwankhunda Township, Blantyre. Telephone interview by author, 15 January 2006, Blantyre, Malawi.

Livingstone, David. Missionary Travels and Researches in South Africa. London, Great Britain: Ward Lock \& Co., Limited, 1910.

Logan, Robert E., and Neil Cole. Raising Leaders for the Harvest. Alta Loma, CA: CRM New Church Development, 1992.

Long, Meredith W. Health, Healing and God's Kingdom: A New Pathway to Health Ministry in Africa. Harrisonburg, VA: R. R. Donnely and Co., 2000.

Longenecker, Harold L. Growing Leaders by Design. Grand Rapids, MI: Kregel Resources, 1995.

Loritts, Crawford W. A Passionate Commitment: Recapturing Your Sense of Purpose. San Bernadino, CA: Here's Life Publishers, Inc., 1989.

Luter, Asa Boyd, Jr. "A New Testament Theology of Discipling." Th.D. diss., Dallas Theological Seminary, 1985.

MacArthur, John. Twelve Ordinary Men: How the Master Shaped His Disciples for Greatness and What He Wants to do with You. Nashville, TN: W Publishing Group, 2002.

Malphurs, Aubrey. Ministry Nuts and Bolts: What They Don't Teach Pastors in Seminary. Grand Rapids, MI: Kregel Publications, 1997. 
. Planting Growing Churches for the $21^{\text {st }}$ Century. Grand Rapids, MI: Baker Books, 1998.

Malphurs, Aubrey, and William Mancini. Building Leaders: Blueprint for Developing Leadership at Every Level of Your Church. Grand Rapids, MI: Baker Books, 2004.

Marlowe, Leigh. Social Psychology: An Interdisciplinary Approach to Human Behavior. Boston, MA: Holbrook Press, Inc., 1975.

Marshak, Robert J. "Introduction: Transforming Thoughts About Change." The Journal of Applied Behavioral Science 41 (June 2005): 157-160.

Martin, Carlos G. Turning the World Upside Down. Nampa, ID: Pacific Press Publishing Association, 2000.

Masoka, Rosemary, a Malawian RN at Lakeland, MI. Interview by author, February 8, 2006, Berrien Springs, MI.

Matthaei, Sondra Higgins. Faith Matters: Faith-Mentoring in the Faith Community. Valley Forge, PA: Trinity Press International, 1996.

. Making Disciples: Faith Formation in the Wesleyan Tradition. Nashville, TN: Abingdon Press, 2000.

Maybee, Maylanne, ed. All Who Minister: New Ways of Serving God's People. Toronto, Ontario: ABC Publishing, 2001.

McCauley, Cynthia D., and Ellen Van Veslor, eds. The Center for Creative Leadership Handbook of Leadership Development. San Fransisco, CA: Jossey-Bass, 2004.

McConnell, Taylor. The Pastor as Educator. Nashville, TN: Local Church Education, Board of Discipleship of the United Methodist Church, 1972.

McFarland, Ken. Christianity Is Not a Spectator Sport: God Needs Players, Not Cheerleaders. Fallbrook, CA: Hart Research Center, 1993.

McGavran, Donald Anderson. Church Growth and Christian Mission. New York, NY: Harper \& Row Publishers, 1965.

McGavran, Donald, and Win Arn. Back to the Basics in Church Growth. Wheaton, IL: Tyndale House Publishers, Inc., 1981.

Messina, Mark, Virginia Messina, and Kenneth D. R. Setchell. The Simple Soybean and Your Health. Garden City Park, NY: Avery Publishing Group, 1994. 
Moon, Gary W., and David G. Benner, eds. Spiritual Direction and the Care of Souls. Downers Grove, IL: InterVarsity Press, 2004.

Moore, Henrietta L., Todd Sanders, and Bwire Kaare. Those Who Play with Fire: Gender, Fertility, and Transformation in East and Southern Africa. London, Great Britain: The Athlone Press, 1999.b

Moorhead, Bob. The Growth Factor. Joplin, MO: College Place Publishing Company, 1991.

Morton, Scott. Down to Earth Discipling: Essential Principles to Guide Your Personal Ministry. Colorado, CO: NavPress, 2003.

Msiska, Stephen Kauta. Golden Buttons: Christianity and Traditional Religion Among the Tumbuka. Blantyre, Malawi: CLAIM, 1997.

Mtike, Harry G. "A Christian Approach to Traditional Male Circumcision Customs in Malawi." D.Min. diss., Andrews University, 1999.

Munthali, Gideon. "Remandee turns into lion, leopard, snake monkey," March 2, 2006. http://www.nationmalawi.com (March 23, 2006).

Musopole, Augustine C. Being Human in Africa: Toward an African Christian Anthropology. New York, NY: Peter Lang Publishing, Inc., 1994.

Muyebe, Stanlaus C. The Catholic Missionaries Within and Beyond the Politics of Exclusivity in Colonial Malawi, 1901-1945. Lewiston, NY: The Edwin Mellen Press, 1999.

Mwale, Kuthemba J. B. “Re: Material for Research on Discipleship!” January 27, 2006. http://www.mwalejbk@yahoo.com (January 27, 2006).

Nelson, Harold D. Area Handbook for Malawi. Washington, DC: Foreign Affairs Studies: FAS of the American University, 1975.

Nelson's New Illustrated Bible Dictionary, 1995 ed. S.v. "Teaching."

Nickless, Mickey. “'Growing in Christ'-A New Statement of Fundamental Belief." Adventist Review, July 5, 2005, 10-11.

Nkhata, Pellie, a Malawian MBA student at Andrews University. Interview by author, February 12, 2006, James White Library.

Nyasulu, Timmothy. Missiology: A Study of the Spread of Christian Faith. Zomba, Malawi: Kachere Series, 2004. 
Ogden, Greg. Discipleship Essentials: A Guide to Building Your Life in Christ. Downers Grove, IL: InterVarsity Press, 1998.

Oosterwal, Gottfried. Patterns of SDA Church Growth in America. Berrien Springs, MI: Andrews University Press, 1976.

Ozinga, James R. The Recurring Dream of Equality: Communal Sharing and Communism Throughout History. Lanham, MD: Univeristy Press of America, 1996.

Pachai, Bridgal. The History of the Nation. London, Great Britain: Longman, 1973. , ed. The Early History of Malawi. Evanston, IL: Northwestern University Press, 1972.

Pejakovich, George. "Leadership Focus: The Importance of Vision." The Army Chaplaincy, Winter 1998, 3-6.

Pendleton; David. "How to Make Your Church Grow: David Pendleton Interviews Pastor Wayne Cordeiro." Ministry, March 2001, 14-17, 29.

Penn, Richard William. "The Call to Discipleship: A Matthean Model for Contemporary Evangelism.” Ph.D diss., The Southern Baptist Theological Seminary, 1989.

Petersen, Jim. Evangelism As a Lifestyle. Colorado Springs, CO: NavPress, 1980, 138139. Quoted in Andy \& Kim Harrison, Seek, Share, Serve, 212. Colorado Springs, CO: NavPress, 2002.

Pierson, Arthur T. The Bible and Spiritual Life. New York, NY: Gospel Publishing House, 1908.

Pocock, Michael, Gailyn Van Rheenen, and Douglas McConnell. The Changing Face of World Missions: Engaging Contemporary Issues and Trends. Grand Rapids, MI: Baker Academic, 2005.

Potholm, Christian P., and Richard Dale, eds. Southern Africa in Perspective: Essays in Regional Politics. New York, NY: Free Press, 1972.

Purves, Andrew, and Charles Partee. Encountering God: Christian Faith in Turbulent Times. Louisville, KY: Westminster John Knox Press, 2000.

Raiser, Konrad. "Opening Space for Cultural Dialogue and Solidarity: The Missionary Objectives of the WCC in an Age of Globalization and Religious Plurality." International Review Mission LXXXVIII (July 1999): 87-96. 
Ransford Oliver. Livingstone's Lake: The Drama of Nyasa Africa's Inland Sea. New York, NY: Thomas Y. Crowell Company, 1967.

Rapport, Nigel, and Joanna Overing. Social and Cultural Anthropology: The Key Concepts. London, Great Britain: Routledge, 2000.

Read, David C. Preaching About the Needs of Real People. Philadelphia, PA: The Westminster Press, 1988.

Rendle, Gilbert R. Leading Change in the Congregation. Bethseda, MD: Alban Institute Publication, 1998.

"Republic of Malawi." CIA Factbook, 2006. http://cia.gov/publications/factbook/geos/mi. html (January 24, 2006).

Rice, Howard. The Pastor As Spiritual Guide. Nashville, TN: Upper Room Books, 1998.

Ridlehoover, Jack. "The Joy of Mentoring." Church Administration, April 2000, 23-25.

Riggs, Charlie. Learning to Walk with God. Minneapolis, MN: World Wide Publications, 1988.

Robinson, Darrell W. Total Church Life: How to be a First Century Church. Nashville, TN: Broadman and Holman Publishers, 1997.

Rosenbach, William E., and Robert L. Taylor. Contemporary Issues in Leadership. Boulder, CO: Westview Press, 1993.

Roy, Ruthven J. "Not Just Membership: Called to Discipleship." Ministry, June 2004, 16$18,27$.

Salhany, Phaize. "Each Alive to Win One in 'Sixty-five'." Trans-Africa Division Outlook, December 15, 1964, 8. $1967,2$.

. "Ninety-Three Baptized in Malawi." Trans-Africa Division Outlook, May 15, $1967,2$.

Samaan, Philip G. Christ's Way of Reaching People: The Fine Art of Relational Witnessing. Hagerstown, MD: Review and Herald Publishing House, 1990. 13.

. "Transformed in Christ for Discipleship." Adventist Review, July 8, 2005, 12-

"Samuel." Seventh-day Adventist Bible Commentary. Edited by F. D. Nichol.

Washington, DC: Review and Herald Publishing Association, 1976. 2:1010. 
Sarli, Joel. "The Ministry of Equipping." Ministry, April 1999, 20-21.

Scazzero, Peter, and Warren Bird. The Emotionally Healthy Church: A Strategy for Discipleship That Actually Changes Lives. Grand Rapids, MI: Zondervan, 2003.

Schalk, Christopher. How to Use the 3 Colors of Ministry in a Mentoring Relationship. Ventura, CA: Regel Books, 1979.

Schutte, A. G. "Dual Religious Orientation in an Urban African Church." African Studies 33 (1974): 113-120.

Schwarz, Christian A. Natural Church Development: A Guide to Eight Essential Qualities of Healthy Churches. Barcelona, Spain: M. C. E. Horeb, 1998.

. The Three Colors of Ministry: A Trinitarian Approach to Identifying and Developing Your Spiritual Gifts. St. Charles, IL: ChurchSmart Resources, 2001.

Seventh-day Adventist Encyclopedia. 1996 ed. S.v. "Malawi."

Shaver, Charles "Chic." Conserve the Converts: A Manual to Help Pastors and Laymen Conserve the Results of Personal and Mass Evangelism. Kansas City, MO: Beacon Hill Press of Kansas City, 1976.

Shurden, Walter B., ed. Proclaiming the Baptist Vision: The Priesthood of All Believers. Macon, GA: Smyth \& Helwys Publishing, Inc., 1993.

Sibande, Francis, a retired Malawian pastor. Interview by author, December 25, 2005, Berrien Springs, MI.

Sindima, Harvey J. Africa's Agenda. Westport, CT: Greenwood Press, 1995.

. Drums of Redemption: An Introduction to African Christianity. Westport, CT: Greenwood Press, 1994.

, a Malawian professor at Colgate University, NY. Telephone interview by author, February 9, 2006, New York.

Sine, Tom. Taking Discipleship Seriously: A Radical Biblical Approach. Valley Forge, PA: Judson Press, 1993.

Skrenes, Thomas A. "Inventing the Future." The Clergy Journal 75 (March 1999): 1214.

[Spicer, W. A.], Editorial. "The Missionary Spirit." The Advent Review and Sabbath Herald, May 27, 1902, 3. 
.The New Missionary Enterprise." The Advent review and Sabbath Herald May 27, 1902, 17.

Spindler, Louise S. Culture Change and Modernization: Mini-Models and Case Studies. Prospect Heights, IL: Waveland Press, Inc., 1984.

Staples, Russell L. Community of Faith. Hagerstown, MD: Review and Herald Publishing Association, 1999.

Stewart, James. Dawn in the Dark Continent or Africa and Its Missions: The Duff Missionary Lectures for 1902. Edinburgh, Great Britain: Oliphant Anderson \& Ferrier, 1903.

Storms, Bruce Allen. "A Program for the Discovery of Spiritual Gifts and Their Development in Lay Ministry." D.Min. diss., Drew University, 1990.

Sundkler, Bengt, and Christopher Steed. A History of the Church in Africa. Cambridge, UK: Cambridge University Press, 2000.

Taylor, John V. The Primal Vision: Christian Presence Amid African Religion. London, Great Britain: SCM Press, 1963.

Telford, Tom. Missions in the $21^{\text {st }}$ Century: Getting Your Church into the Game. Wheaton, IL: Harold Shaw Publishers, 1998.

Terry, John Mark. Church Evangelism: Creating a Culture for Growth in Your Church. Nashville, TN: Broadman \& Holman Publishers, 1997.

Terry, Marion. "Making a Difference in Learners' Lives: Results of a Study Based on Adult Literacy Program." Adult Basic Education: An Interdisciplinary Journal for Adult Literacy Educators 16 (Spring 2006): 9.

[Thiessen, Carol R]. Editorial. "Make Disciples, Not Just Converts." Christianity Today, October 25, 1999, 28-29.

Thiessen, John Caldwell. A Survey of World Missions. Rev. ed. Chicago, IL: Moody Press, 1961.

Thomas, Norman E. Classic Texts in Mission and World Christianity. Maryknoll, NY: Orbis Books, 1995.

Thorpe, S. A. African Traditions: An Introduction. Pretoria, South Africa: University of South Africa, 1991.

Toler, Stan, Dan Casey, and Dan Walters. Growing Disciples: Equipping Christians for Worship, Fellowship, and Ministry. Kansas City, MO: Beacon Hill Press, 2000. 
Tollefson, Kenneth. "Maintaining Quality Control in Christian Missions." Missiology: An International Review XVIII (July 1990): 315-328.

Treston, Kevin. Creative Christian Leadership: Skills for More Effective Ministry. Chicago, IL: Moody Press, 1983.

Turner, Max. The Holy Spirit and Spiritual Gifts Then and Now. Carlisle, UK: Paternoster Press, 1996.

Ulrich, Margie Littel. "Pastor as a Leader: Job Impossible." Ministry, July-August, 2005, $72-73,81$.

Van Gennep, Arnold. The Rites of Passage. Translated by Monika B. Vizedom and Gabrielle L. Caffee. Chicago, IL: The University of Chicago Press, 1960.

Wagner, Alfred M. Training the Laity for Personal Work. Columbus, OH: Lutheran Book Concern, [n.d].

Wagner, Peter C. Your Spiritual Gifts Can Help Your Church Grow. Ventura, CA: Regal Books, 1979.

Waldrup, Earl. New Church Member Orientation Manual, Rev. ed. Nashville, TN: Convention Press, 1970.

Warren, Rick. The Purpose Driven Life: What on Earth Am I Here For? Grand Rapids, MI: Zondervan, 2002.

Watson, David Lowes. Class Leaders: Recovering a Tradition. Nashville, TN:

Discipleship Resources, 1991.

White, Edwin E. The Story of Missions. New York, NY: Friendship Press, 1926.

White, Ellen G. The Acts of the Apostles. Boise, ID: Pacific Press Publishing Association, 1911.

. Christian Service. Washington DC: Review and Herald Publishing Association, 1983.

. Christ's Object Lessons. Washington, DC: Review and Herald Publishing House, 1941.

. Counsels on Stewardship. Takoma Park, MD: Review and Herald Publishing Association, 1940.

. The Desire of Ages. Boise, ID: Pacific Press Publishing Association, 1940. 
. Education. Mountain View, CA: Pacific Press Publishing Association, 1952.

. Evangelism. Washington, DC: Review and Publishing Association, 1974.

. Fundamentals of Christian Education. Nashville, TN: Southern Publishing Association, 1923.

.Gospel Workers. Washington, DC: Review \& Herald Publishing Association, 1915.

. The Great Controversy. Boise, ID: Mountain, CA: Pacific Press Publishing Association, 1950.

. Medical Ministry. Boise, ID: Pacific Press Publishing Association, 1963.

. Ministry of Healing. Mountain View, CA: Pacific Press Publishing Association, 1942.

. Our High Calling. Washington, DC: Review and Herald Publishing Association, 1961. 1958.

. Patriachs and Prophets. Boise, ID: Pacific Press Publishing Association,

. Prophets and Kings. Boise, ID: Pacific Press Publishing Association, 1943.

. Selected Messages. Vol. 3. Washington, DC: Review and Herald Publishing Association, 1980.

. Sons and Daughters. Washington, DC: Review and Herald Publishing Association, 1983. 1956.

Steps to Christ. Mountain View, CA: Pacific Press Publishing Association, . Testimonies for the Church. Vol. 3. Boise, ID: Pacific Press Publishing Association, 1948.

. Testimonies for the Church. Vol. 6. Boise, ID: Pacific Press Publishing Association, 1948.

. Testimonies for the Church. Vol. 7. Boise, ID: Pacific Press Publishing Association, 1948.

. That I May Know Him. Washington, DC: Review and Herald Publishing Association, 1964. 
Upward Look. Washington, DC: Review and Herald Publishing Association, 1982.

Voice in Speech and Song. Boise, ID: Pacific Press Publishing Association, 1988.

Wiersbe, David, and Warren W.Wiersbe. Making Sense of the Ministry. Chicago, IL:Moody Press, 983.

Wilkins, Michael J. Following the Master: A Biblical Theology of Discipleship. Grand Rapids, MI: Zondervan Publishing House, 1992.

Willmon, William H., and Robert L. Wilson. Rekindling the Flame: Strategies for a Vital United Methodism. Nashville, TN: Abingdon Press, 1987.

Wilson, George Herbert. The History of Universities, Mission to Central Africa. Freeport, NY: Books for Libraries Press. 1936.

Young, Terry. After the Fishermen: How Did Jesus Train His Disciples? Carlisle, Great Britain: Paternoster Press, 2004.

Zahniser, A. H. Mathias. Symbol and Ceremony: Making Disciples Across Cultures. Monrovia, CA: MARC, 1997. 


\section{VITA}

\section{Personal Background}

Name

Date of Birth

Place of Birth

Ordination

\section{Educational Background}

2006

2005

!997-1999

1981-1984

1973-1977

\section{Work Experience}

1989-1997

1986-1988

1984-1985

1980-1983

1980-1983

1977-1979

1974-1977

1967-1969
Wenson Lyson Masoka

September 28, 1947

Nseula Village, T. A. Dambe, Neno-Mwanza, Malawi

January 12,1980
Doctor of Ministry in World Mission (Andrews University, USA)

Michigan Prison Ministry Chaplaincy Certification

M.Div. Equivalency (Andrews University, USA)

M.A. in Religion (Andrews University, USA) Helderberg Campus

B. A. in Theology, Solusi College, Zimbabwe

President, Malawi Union MU), Malawi

Secretary, Malawi Union (MU), Malawi

President, South Malawi Mission Field (SMF), Malawi

Tutor-Registrar, Lakeview Seminary, Malawi

Pastor, Lakeview District, Central Malawi Mission Field, (CMF), Malawi

Associate Evangelist, Malawi Union, Malawi

Literature Evangelist, Zambezi Union, Zimbabwe

Custodial Services, Malamulo-Blantyre Adventist Clinic, Malawi 